\title{
THE UPPER MISSISSIPPIAN BLUEFIELD FORMATION IN THE CENTRAL APPALACHIAN BASIN: A HIERARCHICAL SEQUENCE STRATIGRAPHIC RECORD OF A GREENHOUSE TO ICEHOUSE TRANSITION
}

\author{
Joel P. Maynard \\ Thesis submitted to the Graduate Faculty of \\ Virginia Polytechnic Institute and State University \\ in partial fulfillment of the requirements of the degree of \\ MASTER OF SCIENCE \\ In \\ GEOLOGICAL SCIENCES \\ Kenneth A. Eriksson, Co-Chair \\ Richard D. Law, Co-Chair \\ William S. Henika \\ December 15, 1999 \\ Blacksburg, Virginia
}




\title{
THE UPPER MISSISSIPPIAN BLUEFIELD FORMATION IN THE CENTRAL APPALACHIAN BASIN: A HIERARCHICAL SEQUENCE STRATIGRAPHIC RECORD OF A GREENHOUSE TO ICEHOUSE TRANSITION
}

\author{
Joel P. Maynard
}

\begin{abstract}
The Upper Mississippian (Chesterian) Bluefield Formation of southeastern West Virginia and southwestern Virginia is the basal unit of the Mauch Chunk Group, a succession of predominantly siliciclastic strata sourced from actively rising tectonic highlands east of the Appalachian Basin. The Bluefield Formation conformably overlies shallow-marine carbonate units of the Greenbrier Group, and is unconformably overlain by incised fluvio-estuarine facies of the Stony Gap sandstone member (Hinton Formation). Outcrops along the Allegheny Front were investigated sedimentologically and structurally, and subjected to gamma ray analysis. Composite outcrop sections from deformed rocks of the Allegheny Front were correlated with the relatively undeformed rocks in the subsurface of the Appalachian Basin to the west using over 100 commercial oil and gas test wells.

Regional subsurface cross-sections and isopachs define a depocenter in the southeastern part of the study area. Measured outcrop sections reveal that the stratigraphic record in the depocenter consists predominantly of meter-scale, upwardshallowing parasequences, each capped by a flooding surface. These parasequences are stacked into four regionally correlatable depositional sequences. On the basin margin to the southwest and northwest, incised valleys, and fewer meter-scale parasequences characterize depositional sequences.

Stacking of parasequences into sequences reflects a hierarchy of greenhouse-type $5^{\text {th }}$ order, and icehouse-type $4^{\text {th }}$ order eustatic changes superimposed on differential subsidence. Due to early Alleghenian thrust loading, the depocenter experienced greater total accommodation, which prevented incision during lowstands. Instead, in the depocenter, lowstands are typified by preservation of $5^{\text {th }}$ order coal-bearing parasequences. Basin-margin areas experienced less total accommodation resulting in development of $4^{\text {th }}$ order lowstand incised valleys and erosive removal of parasequences. This study demonstrates that both tectonic and eustatic forcing mechanisms controlled stratigraphic evolution of the Bluefield Formation.
\end{abstract}




\section{ACKNOWLEDGEMENTS}

I would like to thank my co-advisors Ken Eriksson and Rick Law for academic and editorial assistance through the years. Their guidance in the lab and in the field are gratefully acknowledged. I have received immeasurable assistance and encouragement from Bill Henika and J. Fred Read during many long discussions and field excursions. Thanks to Fred for the use of the gamma ray scintillometer, and other various tools borrowed in the course of my field work.

I wish to thank Brian Coffey, Daniel Miller, and Thomas Wynn for insights, constructive criticisms, and technical support with various aspects of the project, including, laboratory, computer, and photographic support. Thanks to the Virginia Department of Mines and Minerals, and Engergy, and the West Virginia Geological Survey for providing well-logs and cuttings. Partial funding for this research was provided through a grant from Sigma Xi. 


\section{CONTENTS}

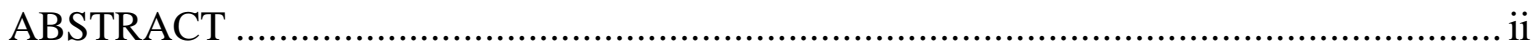

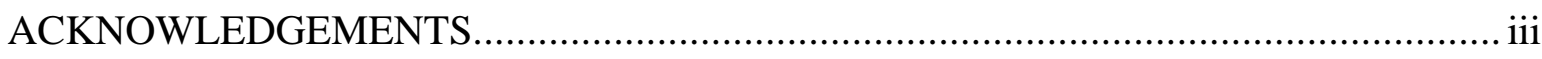

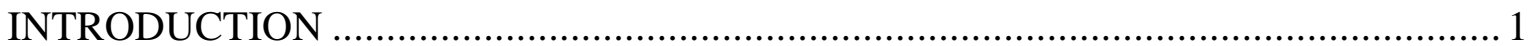

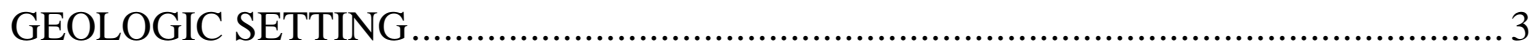

Generalized Late Mississippian Stratigraphy ................................................. 3

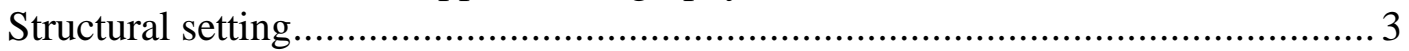

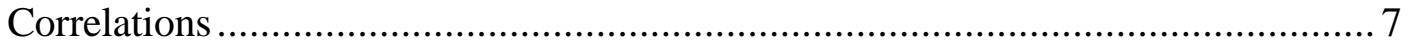

Paleoclimate and Paleogeography ................................................................ 8

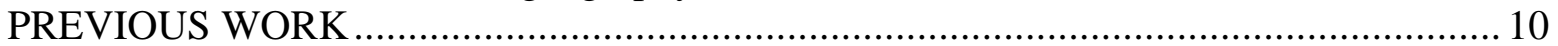

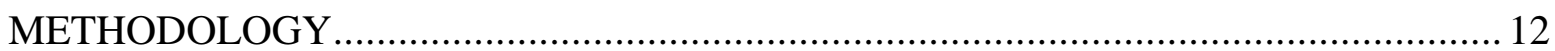

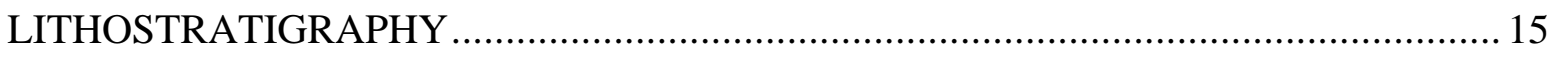

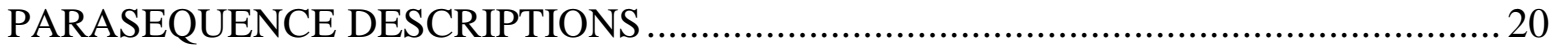

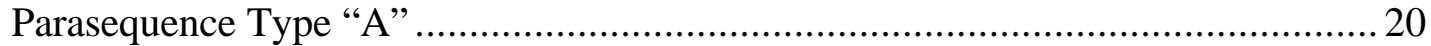

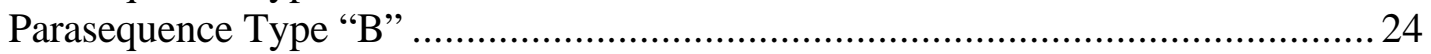

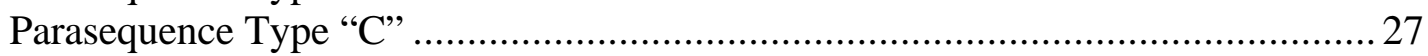

Parasequence Type "D" ........................................................................................ 33

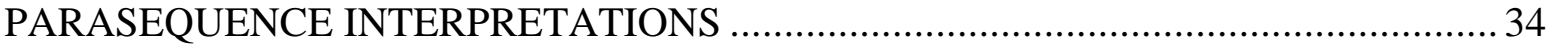

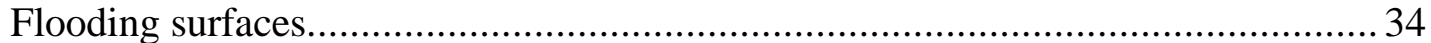

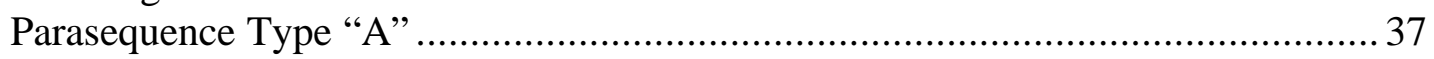

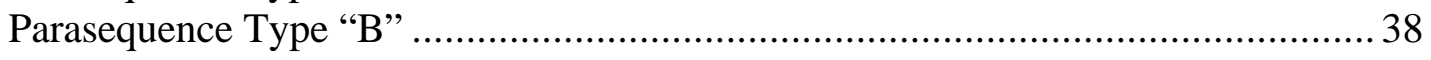

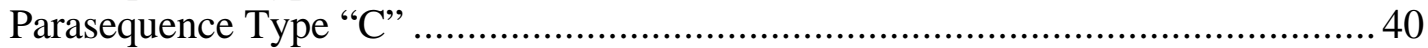

Parasequence Type "D" ................................................................................ 42

SPATIAL AND TEMPORAL RELATIONSHIPS OF PARASEQUENCES ...................... 43

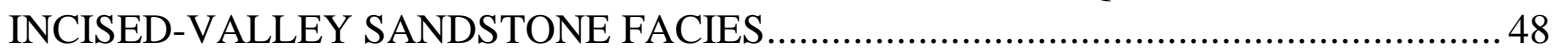

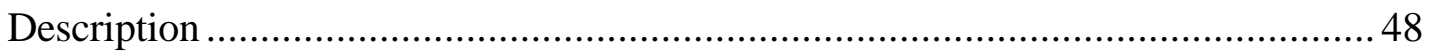

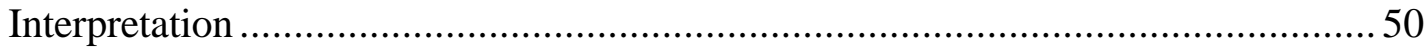

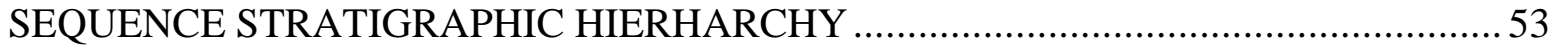

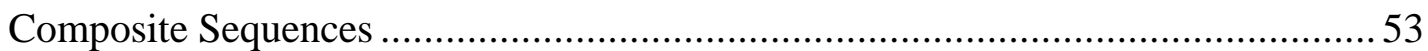

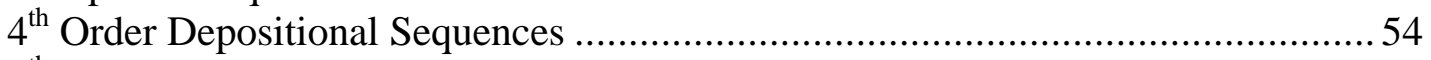

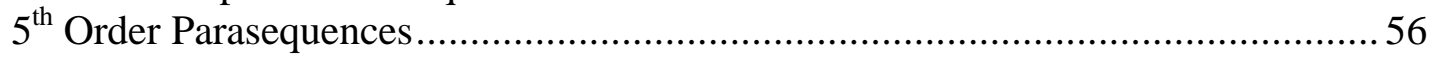

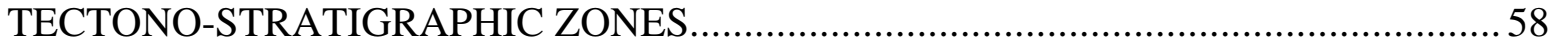

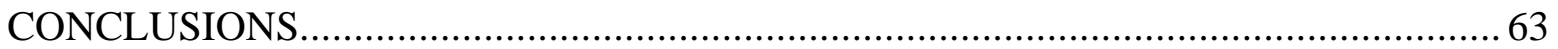

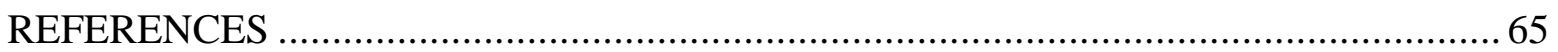

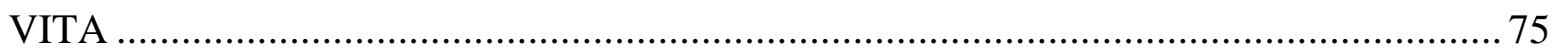

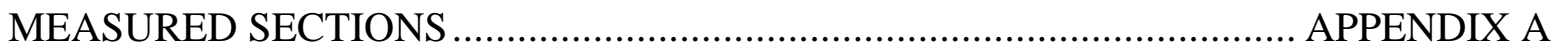

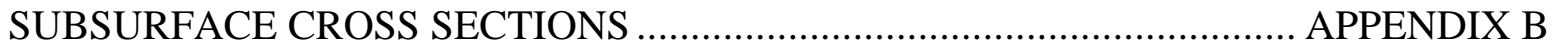

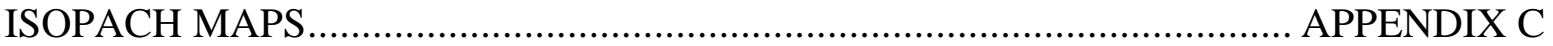

ORIENTED STRUCTURAL PANEL DIAGRAMS ……........................... APPENDIX D

GLEN LYN PALEOCURRENT DATA, AND STRUCTURAL

RESTORATION PROCEDURES 


\section{LIST OF FIGURES}

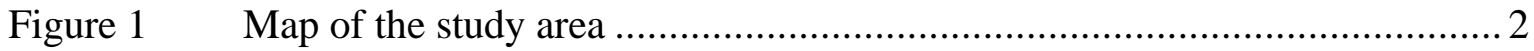

Figure 2 Stratigraphic column of the Mauch Chunk Group ........................................ 4

Figure 3 Isopach map of Mauch Chunk Group ………........................................... 5

Figure $4 \quad$ Schematic diagram of structural features in study area ............................... 6

Figure 5 Late Mississippian paleogeographic reconstruction.................................. 9

Figure 6 Late Mississippian sequence stratigraphy................................................. 11

Figure 7 Lithologic composite and gamma ray log from Oakvale, WVA ................... 13

Figure $8 \quad$ Location map of outcrops, well logs, and cross sections............................... 14

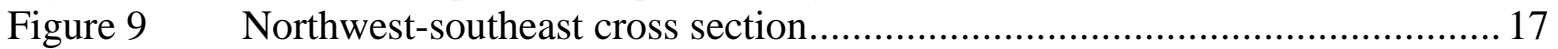

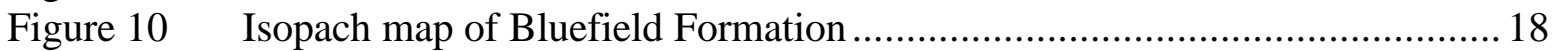

Figure 11 West/southwest-east/northeast cross section .............................................. 19

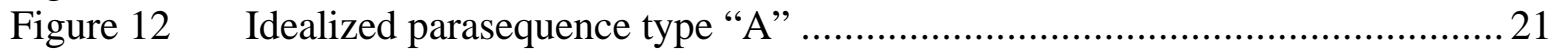

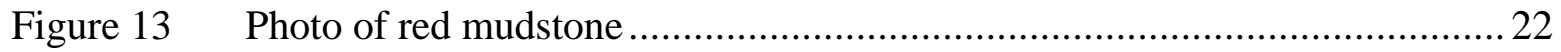

Figure 14 Photomicrograph of algal carbonate mudstone...........................................2 24

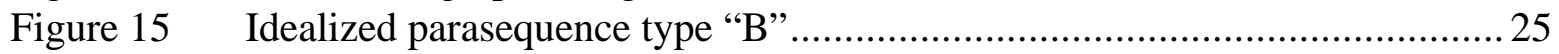

Figure 16 Photo of rhythmically bedded siltstones and mudstones..............................26

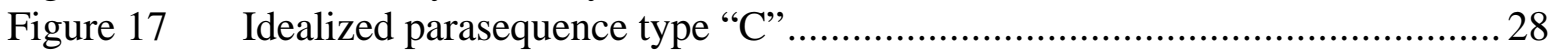

Figure 18 Photo of skeletal carbonate packstone/wackestone.....................................2 29

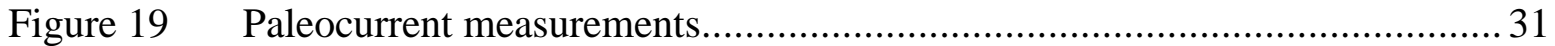

Figure 20 Photos of combined flow ripples................................................................... 32

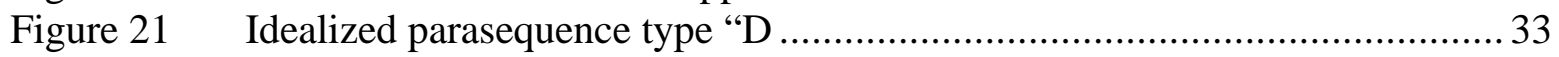

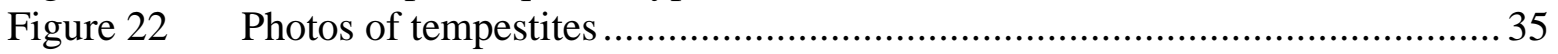

Figure 23 Block diagram of interpreted depositional system ..................................... 45

Figure 24 Block diagram of interpreted depositional system (transgression) ................. 47

Figure 25 Block diagram of interpreted depositional system (regression)...................... 49

Figure 26 Photo of sandstone bodies near Jenkins, Kentucky ..................................... 51

Figure 27 Incised valley fills in cross section........................................................5 52

Figure 28 Schematic of erosional and conformable sequence boundaries .....................6 60

Figure 29 Distribution of coal bearing parasequences in Oakvale section.....................61 61

Figure 30 Schematic illustration of eustatic and subsidence driven accommodation..... 62 


\section{INTRODUCTION}

Greenhouse conditions are typified by high-frequency, low-amplitude sea-level fluctuations, whereas icehouse conditions are characterized by low-frequency, highamplitude eustatic changes. In the rock record, the former have been classically recognized by the presence of meter-scale, upward-shallowing cycles in carbonate successions (e.g. Montanez \& Osleger 1993; Smith, 1996; Pope \& Read 1997; Al-Tawil, 1998), whereas the latter are most commonly recorded by low-frequency, unconformity bounded sequences typified by Pennsylvanian cyclothems (e.g. Heckel, 1986; Veevers \& Powell 1987; Klein \& Willard 1989).

Carboniferous rocks of the Appalachian foreland basin were deposited during a climatic transition from greenhouse conditions, with small global ice volumes, to icehouse conditions associated with the buildup of the Gondwana continental glaciation in the southern hemisphere. The late Mississippian Bluefield Formation in southern West Virginia and southwest Virginia (Fig. 1) records up to 3 million years of this greenhouse to icehouse transition as well as a transition, from arid to ever wet conditions. In this paper we present evidence for a sequence stratigraphic hierarchy in the Bluefield Formation that documents several orders of sea-level change in a tectonically-active foreland basin. Previously undocumented meter-scale, predominantly siliciclastic, upward-shallowing cycles record high-frequency, low-amplitude greenhouse-type conditions. The cycles are stacked into longer-term, icehouse-type sequences that are associated with unconformity-bounded composite sequences. Siliciclastic, meter-scale cycles comparable to those present in the Bluefield Formation are widely reported from lacustrine settings (e.g. Olsen, 1990), but are poorly documented from marine basins. 


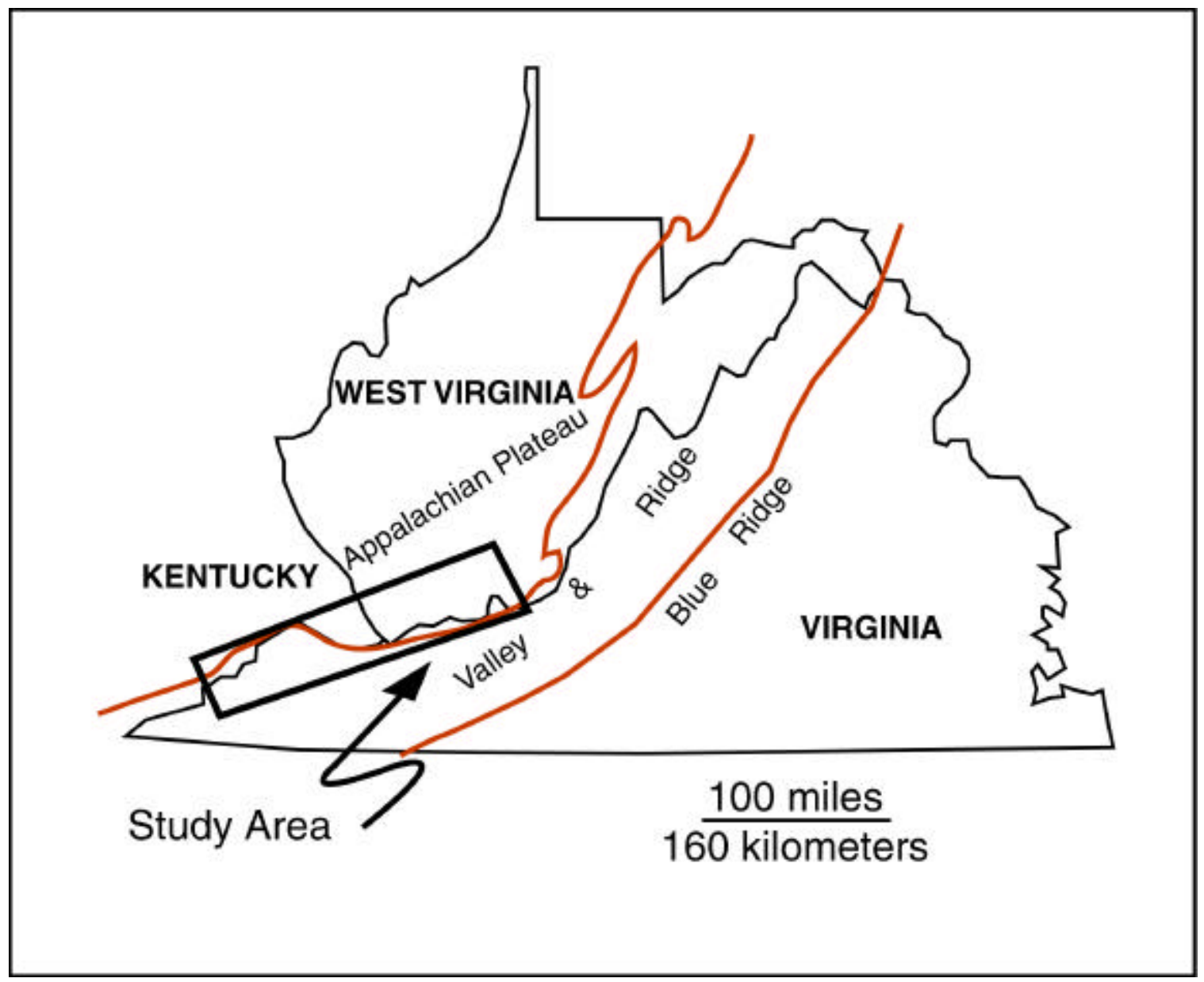

Figure 1: Map showing location of study area with respect to geologic provinces of the central Appalachians. 


\section{GEOLOGIC SETTING}

\section{Generalized Late Mississippian Stratigraphy}

In southern West Virginia and southwestern Virginia, the late Mississippian stratigraphic record is represented by predominantly carbonate rocks of the Greenbrier Group, and predominantly siliciclastic rocks of the Mauch Chunk Group. Four formations make up the Mauch Chunk Group in southern West Virginia; in ascending stratigraphic order these are the Bluefield, Hinton, Princeton, and Bluestone formations (Fig. 2). The Mauch Chunk Group is a westward-tapering wedge with a maximum thickness of over $900 \mathrm{~m}$ (3000’) in southeastern West Virginia (Fig. 3).

During the Late Mississippian, the Appalachian Basin formed a foreland trough that extended from Alabama to southern Pennsylvania (Donaldson and Shumaker, 1981). During the middle Chesterian, Mauch Chunk siliciclastic sediments are thought to have prograded from tectonic highlands to the east, into a narrow embayment that opened to the southwest (DeWitt \& McGrew, 1979; Scotese et al., 1979; Englund \& Thomas, 1990).

\section{Structural setting}

In the eastern portion of the study area, the Bluefield Formation outcrops in synclinal and anticlinal structures along the Allegheny Front (Rodgers, 1964). The Allegheny Front is a transition zone between the folded and faulted sedimentary rocks of 
the Valley \& Ridge Province to the southeast, and the gently dipping, relatively

undeformed strata of the Appalachian Plateau. In this study, data from exposures along

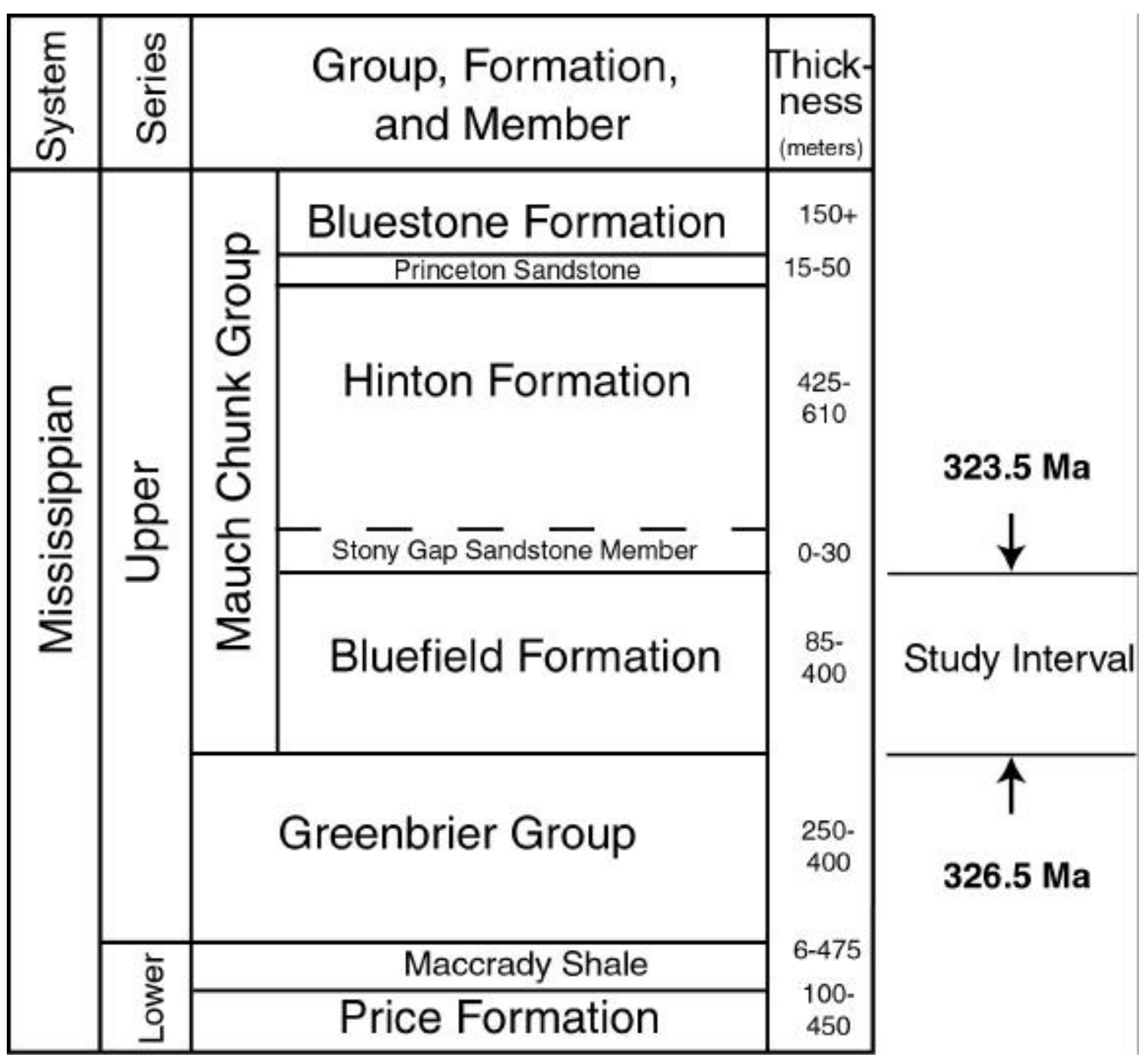

Figure 2: Generalized Upper Mississippian stratigraphic column in southern West Virginia. Age constraints based on Jones (1996). 


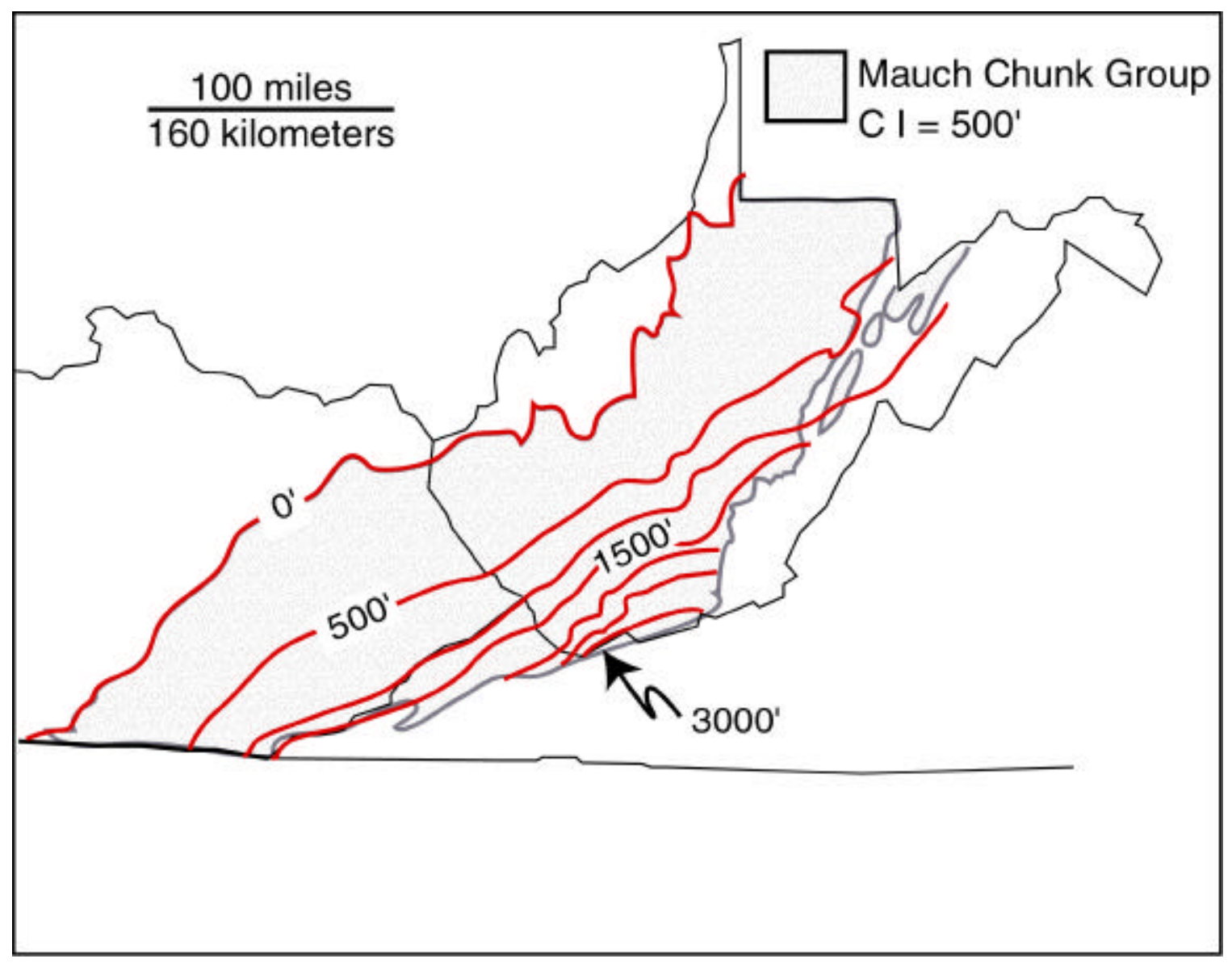

Figure 3: Isopach map of the Mauch Chunk Group showing southeastward thickening trend. Figure modified from Arkle (1979).

the structural front are combined with commercial subsurface data in West Virginia and southwest Virginia.

In the outcrop study area, the Glen Lyn syncline is the dominant structure. First noted by Campbell (1896) and described by Reger (1926) as the Hurricane Ridge Syncline, it was later divided into three separate synclines (from southeast to northwest, the Glen Lyn, Hurricane Ridge, and Caldwell synclines) by McDowell (1982). The later two synclines are open folds with relatively shallow dipping limbs (Fig. 4). The Glen 


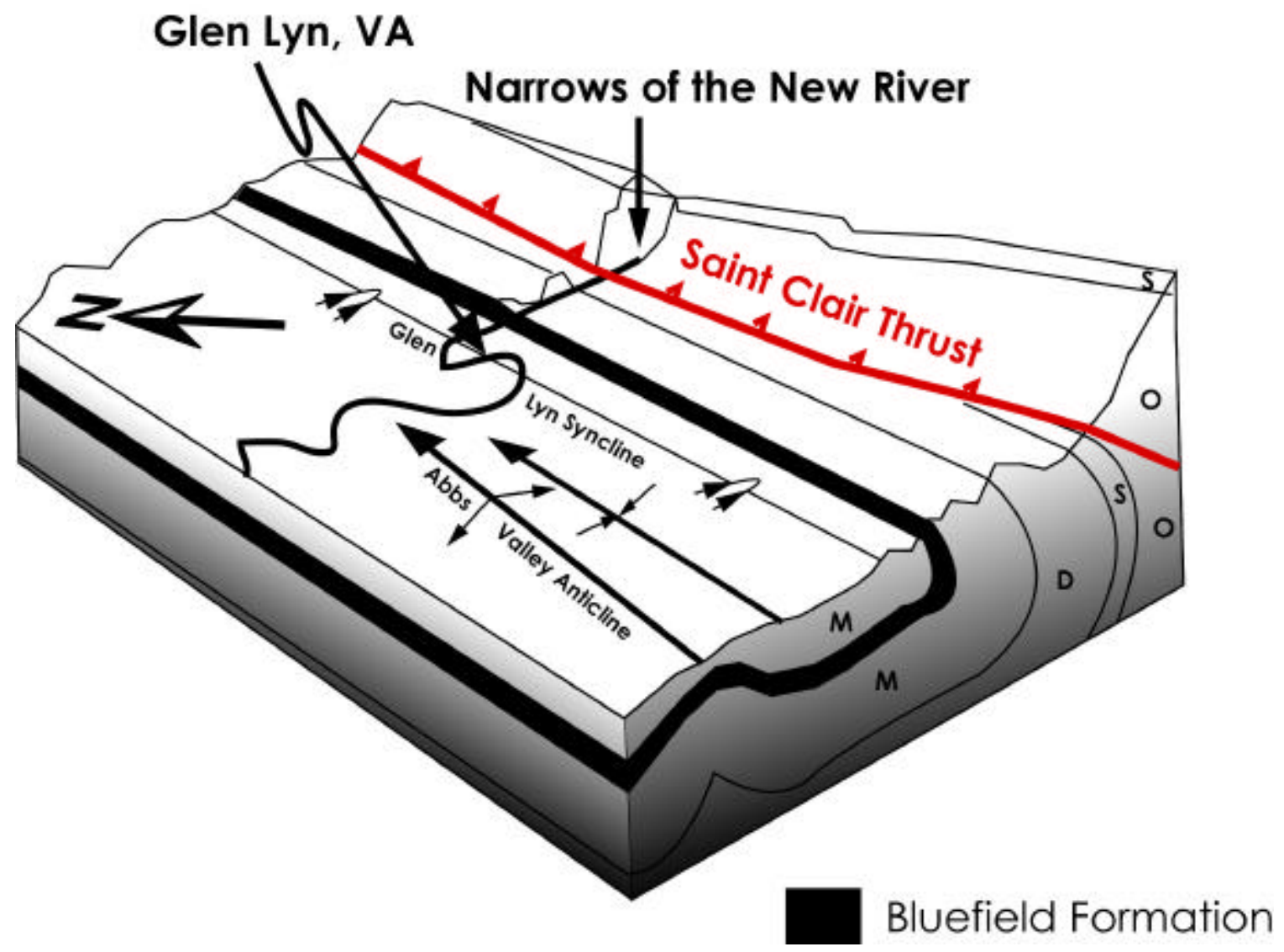

Figure 4: Generalized block diagram showing structural control on exposure of the Bluefield Formation in the northeastern portion of the study area. Figure modified from Melhop and Dennison (1996). $M=$ Mississippian, $D=$ Devonian, $S=$ Silurian, $O=$ Ordivician.

Lyn syncline is developed in the footwall of the St. Clair thrust fault with and has steeply-dipping to overturned eastern limb. This syncline is probably related to movement along the St. Clair thrust fault and may be the result of ramping of a deep decollement to the southeast, combined with drag effects on the footwall (McDowell, 1982). In the eastern portion of the study area, the St. Clair thrust fault at outcrop is a knife-edge plane dipping about $30^{\circ}$ to the southeast (Cooper, 1961). The fault extends from the core of an anticline located in southwestern Alleghany County, Virginia, 
southwestward for more than $150 \mathrm{~km}$ to Richlands, VA., and nearly $450 \mathrm{~km}$ farther into northwestern Georgia as the Clinchport and related thrust faults (McDowell, 1982).

Southwestern portions of the study area are transected by the Russell Fork fault zone associated with the Cumberland (Pine Mountain) overthrust block. The Pine Mountain thrust sheet is limited to the northeast by the Bishop-Bradshaw lineament (Cambria Fault). Structural studies along the Russell Fork fault by Henika (1994), reveal a high-angle fault zone with strain indicators which show normal, reverse and transpressional movement. The Russel Fork fault offsets the St. Clair fault laterally approximately 1 kilometer, where it is named the St. Paul overthrust and continues it's general NE-SW trend (Miller, 1973; Henika, 1994).

Small fault offsets (both normal and reverse motion) are pervasive in outcrops in the northeastern part of the study area. Displacements average roughly 20-50 centimeters, and rarely exceed 10 meters. These small structures have been used as evidence for penecontemporaneous sedimentary slumping (Cooper, 1961; Thomas, 1966), post-depositional extensional structures related to Alleghenian rotational thrusting (Henika, 1994), and part of a relatively young, post-Alleghenian extensional zone (Melhop et al., 1996).

\section{Correlations}

Fossils found in the Bluefield Formation are equivalent to the Glen Dean Formation within the midcontinental Chesterian type section. An extensive list of fossil forms was assembled by Reger (1926), Butts (1940), and Cooper (1944). The equivalence to the Glen Dean is based on the forms Pentremites gadoni abbreviatus 
?Hambach [=P. brevis Ulrich], P. elegans Lyon [ = P. canalis Ulrich], $P$. pyramidatus

Ulrich, Pterotocrinus spatulata Wetherly, and Prismopora serrulata Ulrich (Butts 1933;

Nolde, 1994).

Correlation of biostratigraphic data with European successions containing geochronological age constraints indicate that the basal portion of the Bluefield Formation correlates with the upper Visean (Brigantian). The upper contact with the Stony Gap sandstone member of the Hinton Formation is no younger than early Namurian A (late/middle Pendleian) (Miller, 1998). Recently improved SHRIMP geochronologic dates for Carboniferous Gondwanan biostratigraphic zones (Roberts et al., 1995) allows for the total time represented by the study interval to be approximated. According to correlation charts assembled by Jones (1996), the Bluefield Formation represents a time interval between 326.5 Ma and 323.5 Ma (Miller, 1998) (Fig. 2).

\section{Paleoclimate and Paleogeography}

Large-scale climatic change is recorded in the Carboniferous and Permian rocks of North America. The abundance of red beds in middle and late Mississippian strata characterize a dry, oxidizing climate, followed by a Pennsylvanian ever-wet climate characterized by abundant coals and a lack of red beds (Cecil 1994; Opdyke and DiVenere, 1994).

One of the primary factors influencing local Late Paleozoic climate was paleolatitude. Paleomagnetic, paleoclimatic, and biogeographic evidence indicate that in late Carboniferous times, the midcontinent of North America moved from the subtropics $\left(20^{\circ} \mathrm{S}\right)$ to a position astride the equator by early Permian (DiVenere and Opdyke, 1991; 
Scotese, 1995). Using remnant magnetism, paleogeographic reconstructions for Bluefield Formation times indicate that the Central Appalachian basin occupied a near equatorial position at approximately $10-15^{\circ} \mathrm{S}$ (Scotese, 1995; Cleal \& Thomas, 1996) (Fig. 5).

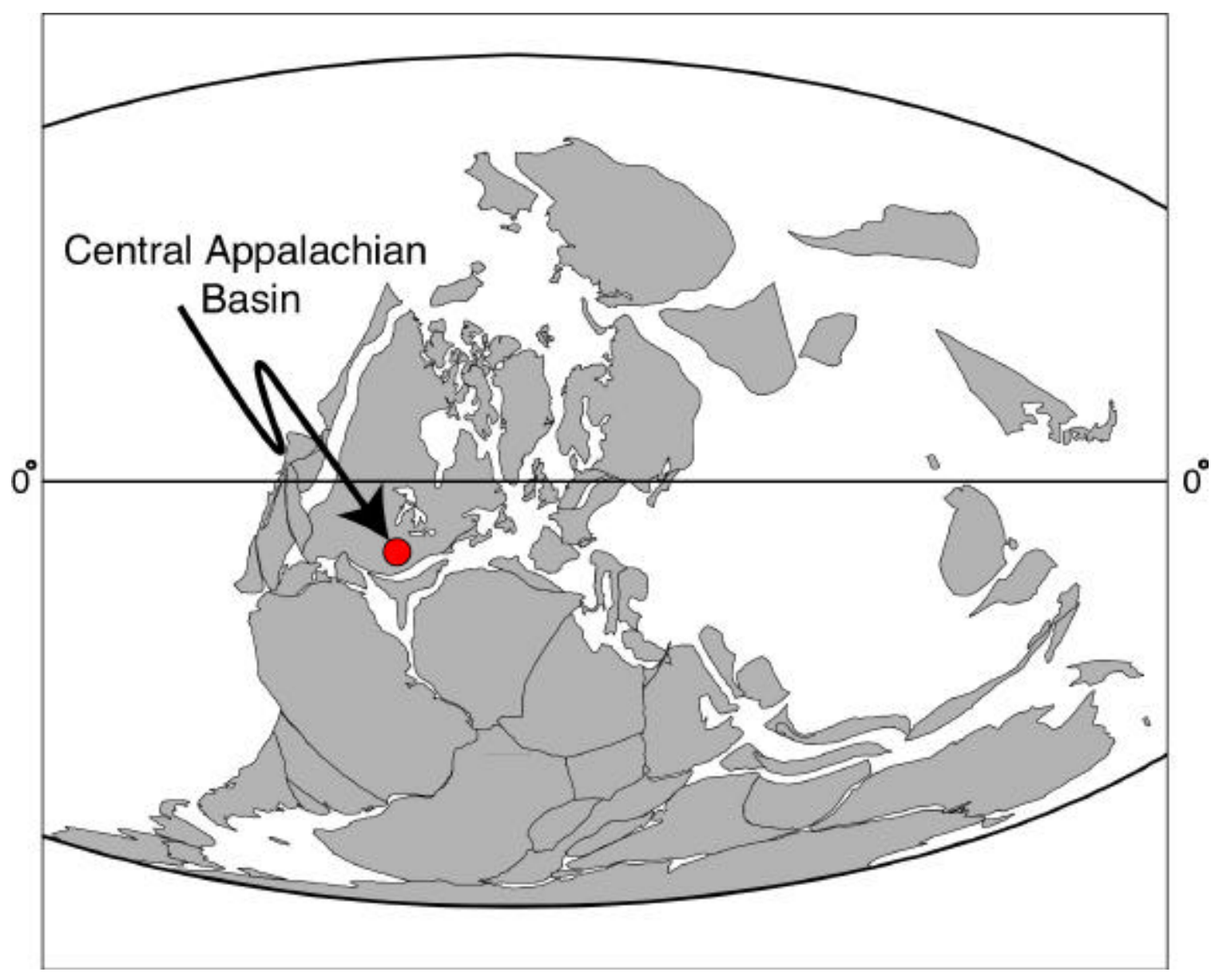

Figure 5: Paleogeographic reconstruction at time of deposition of the Bluefield Formation. The study area was located in near-equatorial latitudes in the middle Mississippian Period. Figure modified from Scotese (1995). 


\section{PREVIOUS WORK}

In 1896, M. R. Campbell named the study interval the Bluefield Shale after the town in Mercer County, West Virginia. It was raised to Group status and subdivided into sixteen formations by Reger (1926). However, most recent workers recognize the Bluefield as a single formation, after most of Reger's sixteen formations were found to be extremely localized (Humphreville, 1981). It is now generally accepted that the Bluefield is a single formation and is the basal member of the Mauch Chunk Group in southern West Virginia. Unfortunately, some of Reger's names are still used by many workers to further differentiate the Bluefield Formation, leading to confusion throughout the years. Overlying the basal 25-40 meters of dark to greenish-gray, micaceaous shale called the Lillydale Shale Member (Reger, 1926; Nolde, 1994) is a 3-4 meter thick skeletal packstone/lime mudstone. This limestone has been called the Reynolds Limestone (Arkle et al., 1979), and the Glen Ray Limestone by (Nolde, 1994), but is commonly called the 'little lime' by drillers. Stratigraphically higher is a sandstone that ranges in thickness from 6-30 meters, and was named the Indian Mills sandstone member by Swires (1972). A younger middle sandstone is sometimes referred to as the Droop member (Arkle, 1979). These sandstone units are commonly referred to as the lower and middle Maxon sands by local drillers. Currently, only three named members of the Bluefield Formation are formally recognized in Virginia; the Lillydale Shale Member, the Glenray Limestone Member, and the Indian Mills Sandstone Member (Nolde, 1994).

Several workers have conducted paleoenvironment and paleoecology studies of marine units in the Bluefield Formation, facilitated by the excellent strike exposure of 
these units within the study area (Whisonant and Scolaro 1980; Humphreville, 1981; Christopher, 1992). Individual theses have also been conducted on the petrology of selected sandstone units throughout the study interval (e.g. Kirkland, 1985).

Only recently has interest been shown in the sequence stratigraphy of Late Mississippian sedimentary rocks in the Appalachian basin. Work by Al-Tawil (1998) has shown that the Greenbrier Group forms the transgressive systems tract of a thick Mississippian supersequence (Fig. 6). The group is composed of twelve back-stepping, fourth-order depositional sequences, with an average duration of between 300 to 400 k.y. each. Al-Tawil (1998) also noted the presence of up to 25 shorter duration parasequences within the Greenbrier Group. Miller (1998) found the Hinton to Bluestone interval of the Mauch Chunk Group to be composed of up to 17 fourth-order unconformity bounded depositional sequences. The sequences can be stacked into two, third-order composite sequences bounded by regional unconformities, and represent the highstand systems tract of the Mississippian supersequence (Fig. 6).

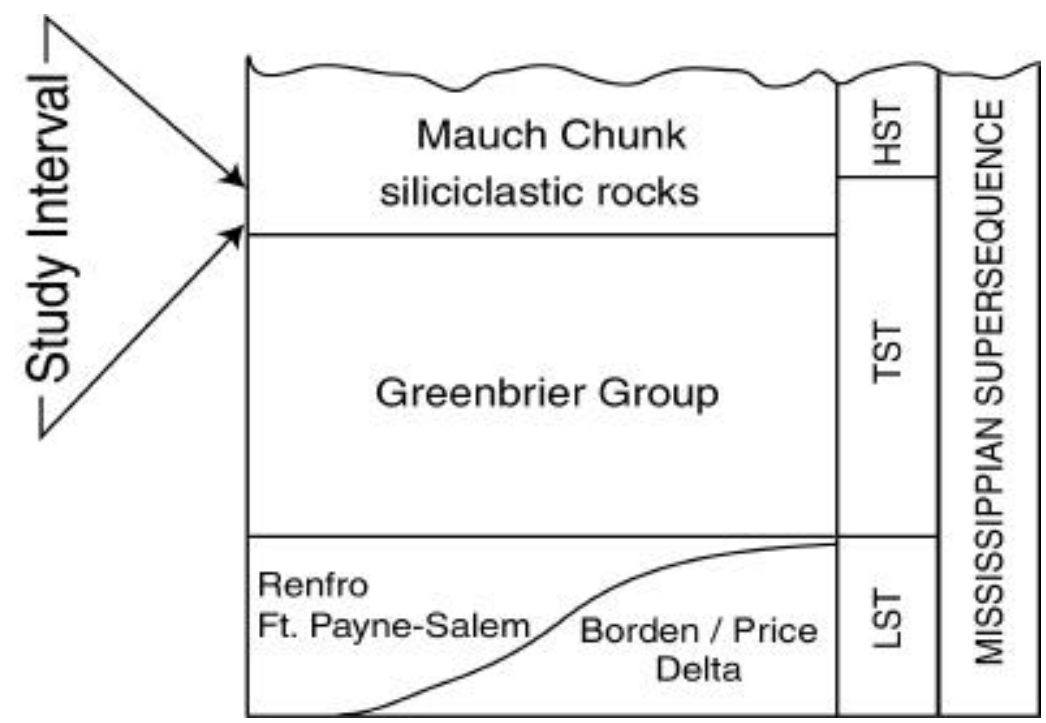

Figure 6: Generalized stratigraphic column showing the position of the study interval within a largescale sequence stratigraphic framework. Figure modified from Al-Tawil (1998) 
Despite the large volume of work pertaining to Upper Mississippian units in the Appalachian basin, published regional cross-sections of the Bluefield Formation are scarce and highly generalized. To date, no published paper examines this key interval in the context of modern sequence stratigraphy.

\section{METHODOLOGY}

Stratigraphic sections through the study interval were measured at the cm-scale and described with regards to lithology, color, fossil content, sedimentary and pedogenic structures, upper and lower contacts, and fault /joint set orientations. These sections were then logged using a hand held gamma-ray scintillometer, producing a distinctive pattern in response to specific outcrop facies of sandstone, shale, and limestone (Fig. 7). The high resolution outcrop and gamma ray composite sections were then correlated across the study area using a database of over 100 oil and gas test wells assembled from the counties of Tazewell, Buchanan, Dickenson, and Wise in Virginia, and Mercer, Raleigh, Wyoming, McDowell, and Logan in West Virginia (Fig. 8). Five cross sections were constructed through the study area. (See Appendix A for cross sections and well locations). Average well spacing is approximately $11 \mathrm{~km}$ : however larger spacings are present due to well log unavailability.

Outcrop sections of the Bluefield Formation were analyzed for faulting and joint patterns, and compared to detailed panel diagrams to examine their spatial relationship to the hinge of the Glen Lyn syncline. This was done in order to determine if faults and joints formed during deposition, or were produced by post-depositional folding and 


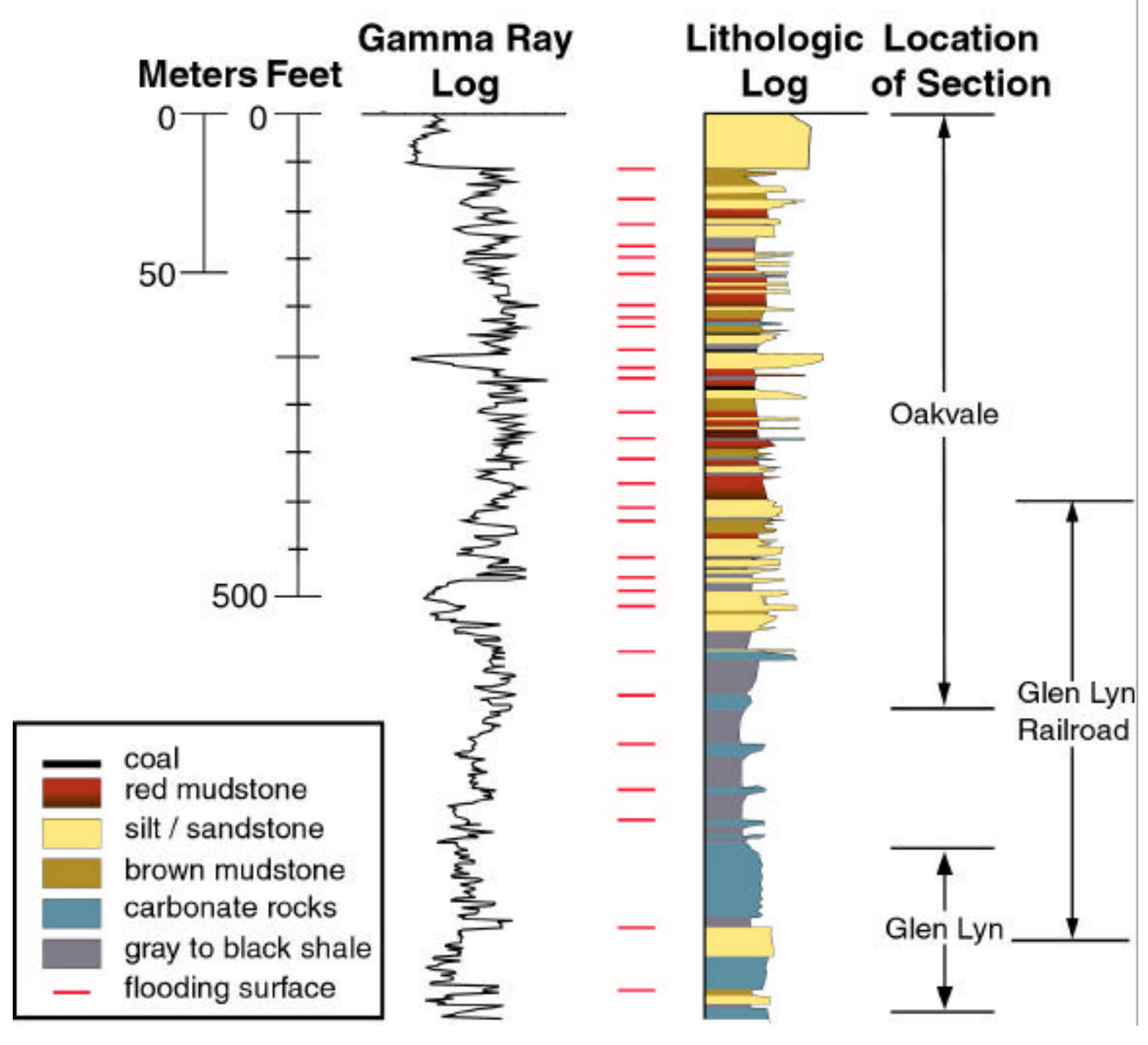

Figure 7: Simplified composite correlation of lithologic sections from the Oakvale-Glen Lyn area with gamma-ray expression. Red lines demarcate flooding surfaces. The representative section is constructed from three nearby locations that stratigraphically overlap. 


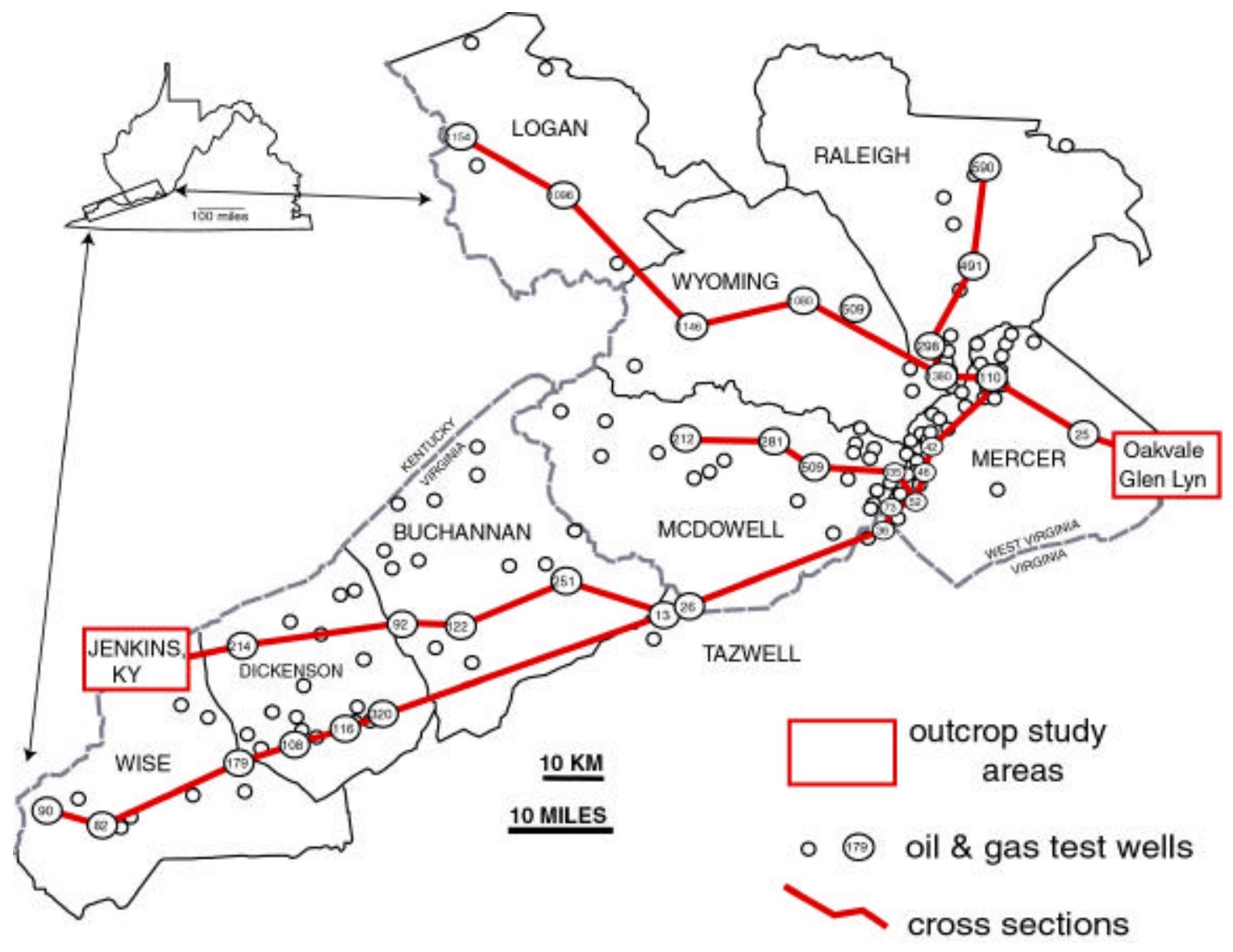

Figure 8: County-scale map showing locations of commercial oil and gas wells used in this study, as well as locations of subsurface cross sections, and sections measured in outcrop.

formation of the Glen Lyn syncline. Unfortunately, the Bluefield Formation is rarely exposed on both the overturned limb and the flat-lying, relatively undeformed limb of the Glen Lyn syncline. Therefore, it was necessary to analyze overlying basal units of the Hinton Formation which could be traced directly through the hinge of the syncline and into the flat-lying limb. Over $240 \mathrm{~m}$ (800') of continuous exposure was measured and surveyed in detail on oriented cross section panels at a scale of 1 inch $=5$ feet (Appendix B). Bedding, fault and joint planes, as well as slicken-line orientations were plotted to 
investigate: 1) the average orientation of faults in the Hinton section, 2) if the average Hinton fault orientations approximates those found in measured Bluefield sections, and 3) if the faulting was related spatially to the hinge of the syncline.

\section{LITHOSTRATIGRAPHY}

The Bluefield Formation conformably overlies the Greenbrier Group. The contact between these two units is described as gradational (Arkle et al., 1979), but in the northeastern part of the study area black shale of the Bluefield Formation sharply overlies massive limestones of the Greenbrier Group. In well logs, a high gamma ray signal and a relatively low bulk density characterize the formation boundary.

The top of the Bluefield Formation is recognized by a sharp contact with the Stony Gap sandstone member (or the upper Maxon Sand used by drillers) of the Hinton Formation. Englund et al. (1979) interpreted the contact to be conformable; however others disagree as to the nature of the Hinton/Bluefield contact (Reger, 1926; Nolde, 1994; Miller, 1998). Subsurface and outcrop gamma ray patterns of the contact are distinctively sharp, and are typically accompanied by an extreme density log spike near the base of the unit. The Stony Gap sandstone member unconformably overlies thick paleosols in the northeastern portion of the study area, and truncates thinly bedded siltstones and mudstones in the southwestern portion of the study area. Regionally, the Stony Gap sandstone member varies between 1 to 50 meters in thickness, and is composed of texturally mature cross-bedded, quartz-arenitic sandstone which fines upwards into inclined heterolithic facies, and is commonly capped by gray paleosols (Miller, 1998). Up to 10 meters of local incision, and a rare pebble conglomerate lag at 
the base of the Stony Gap sandstone member, suggest an incised fluvio-estuarine origin (Miller, 1998). Data from this study confirm the existence of an unconformity at the base of the Stony Gap sandstone member.

Cross-sections and isopachs constructed for the Bluefield Formation indicate a wedge-shaped, eastward-thickening package of sediment (Figs. 9, 10). Maximum thickness approaches 360 meters near the eastern border of Mercer county, West Virginia (Fig. 10). The region of greatest thickness reflects maximum overall accommodation in the southeast, whereas thinner sections to the northwest represent less total accommodation. These two generalized areas are referred to later in the text as the depocenter and basin margin locations, respectively.

The Bluefield Formation can be divided into lower carbonate-dominated and upper siliciclastic dominated intervals (Figs. 9, 11). In general, the lower Bluefield Formation is dominated by marine facies of skeletal carbonates rocks, carbonaceous mudstones, and black shale. The upper Bluefield is primarily composed of heterolithic siliciclastic sediments that vary laterally in thickness and composition. The Bluefield Formation is further divisible into four distinct packages, which are regionally traceable and recognizable in outcrop (Figs. 9, 11). The upper two packages (3 and 4) are unconformity bounded through much of the subsurface study area, and can be traced into areas of correlative conformity in eastern Mercer county. Regionally developed shale horizons with distinctive high gamma ray signals, and low bulk densities, form bounding surfaces for the lower two packages (1 and 2). 
NW SE

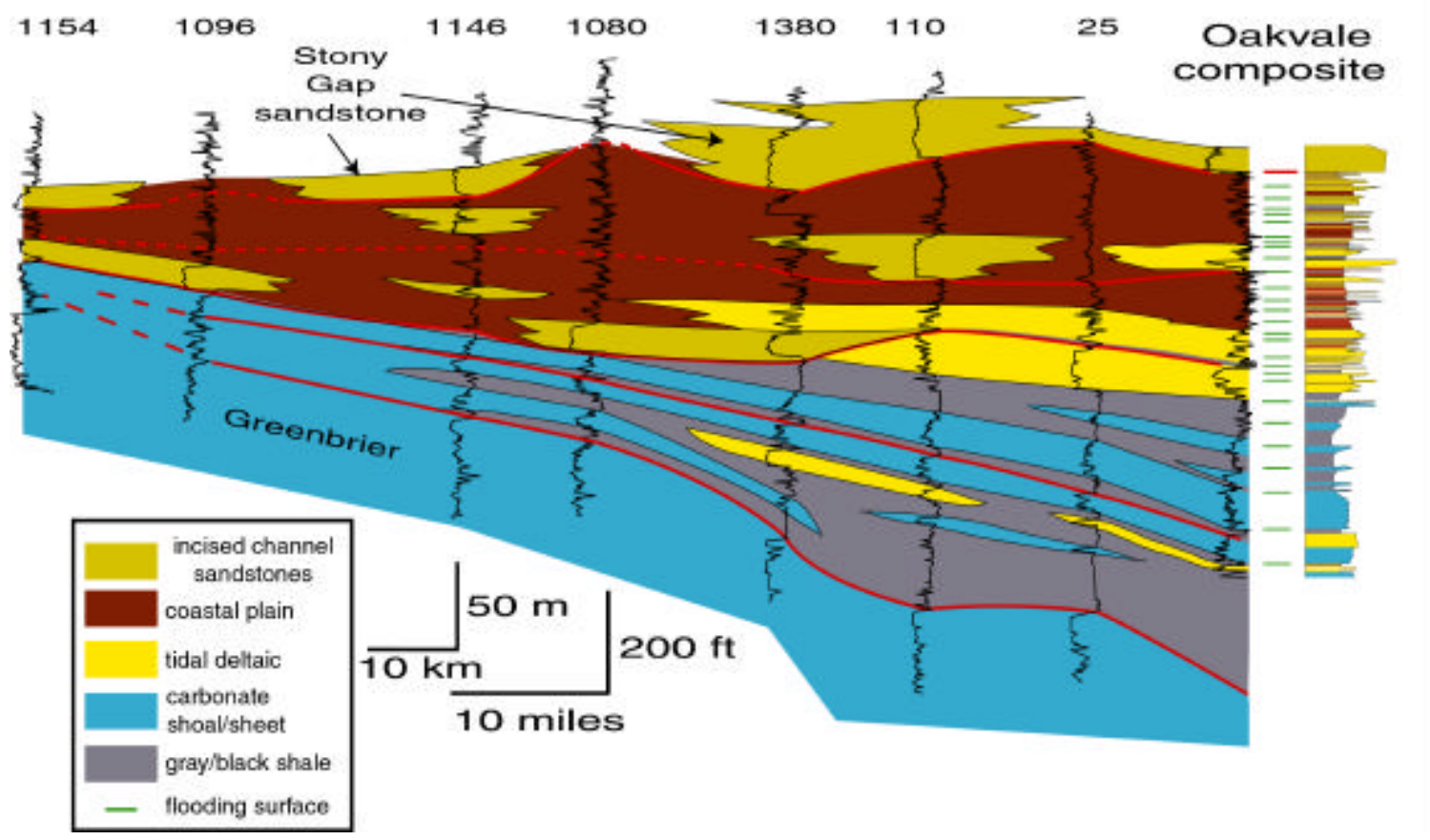

Figure 9: Interpreted northwest-southeast well-log cross section tied into composite Oakvale outcrop section using hand-held gamma-ray measurements. Cross section shows northwestward-tapering wedge. Note that the Bluefield Formation can be divided into upper siliciclastic dominated- and lower carbonate/shale-dominated intervals. It can be further subdivided into four regionally traceable packages. Well log and outcrop locations indicated in Figure 8. 


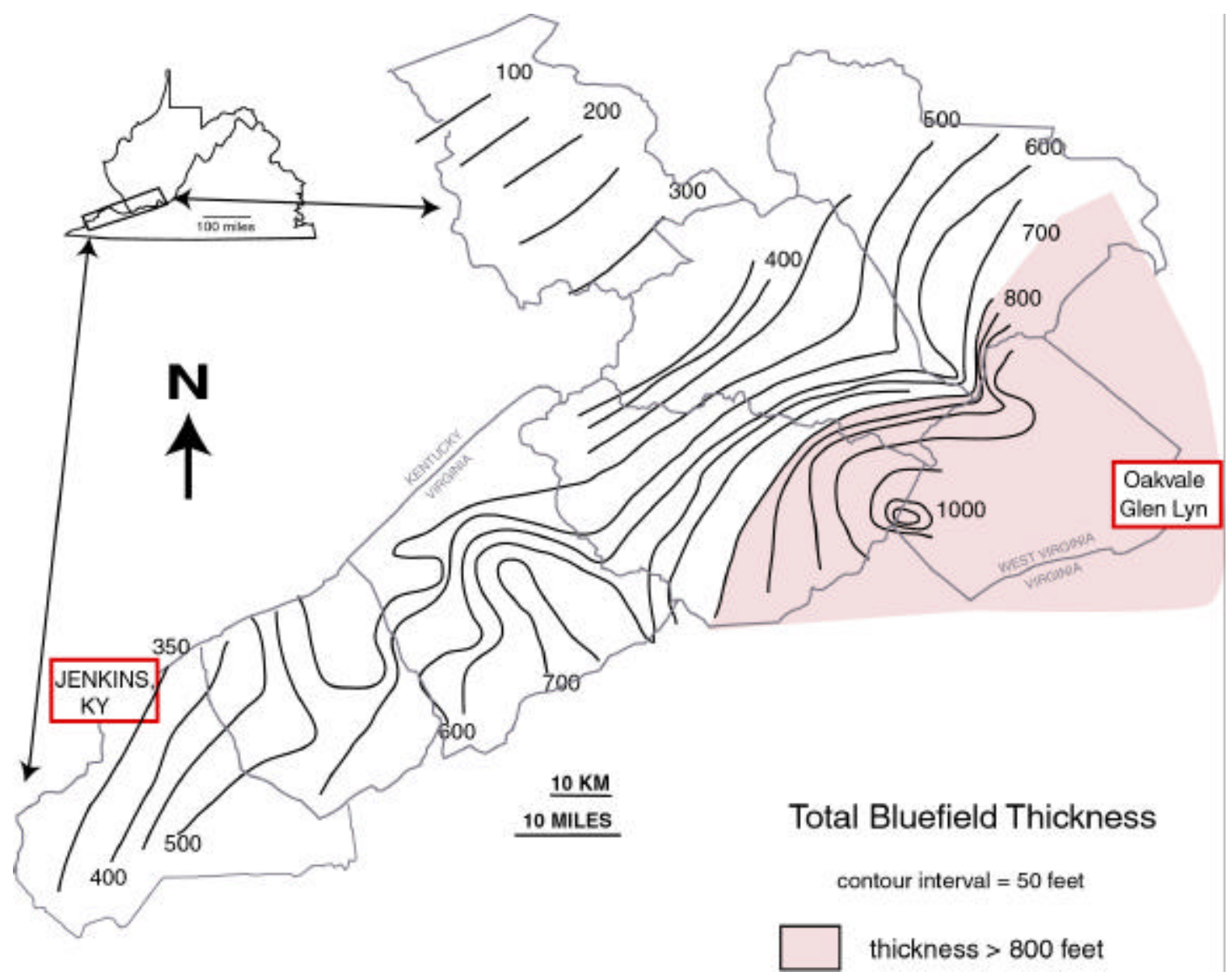

Figure 10: Isopach map showing total Bluefield Formation thickness. Map is based on well logs and outcrop-measured sections. Region where Bluefield Formation is greater than 600 feet $(180 \mathrm{~m})$ thick is referred to as depocenter in text. Regions peripheral to depocenter are referred to as basin-margin locations. 


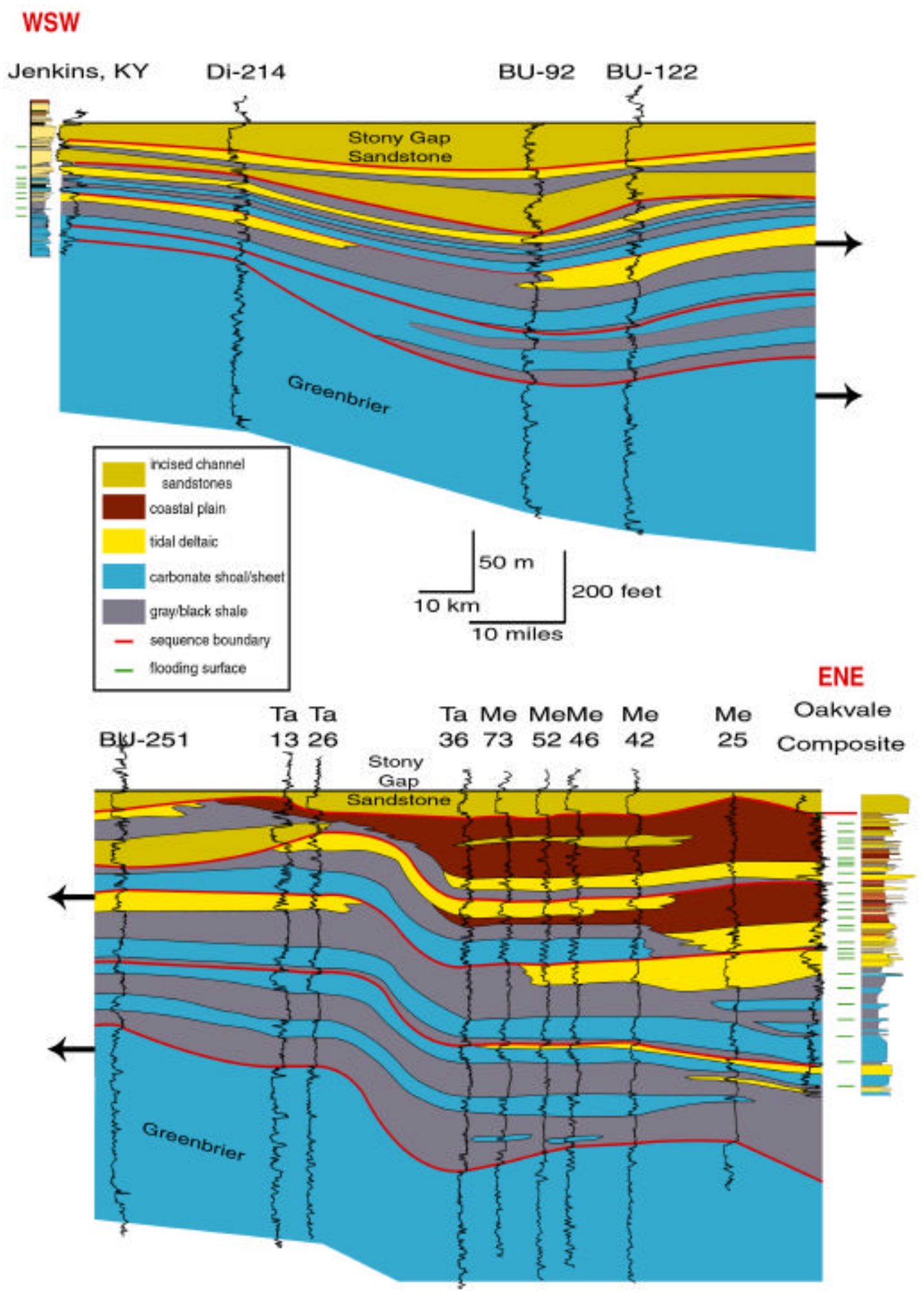

Figure 11: Interpreted northeast-southwest well-log cross section tied into outcrop sections using hand-held gamma-ray measurements. This cross section also illustrates the upper siliciclastic dominated-, and lower carbonate/shale-dominated intervals of the Bluefield Formation, as well as the four regionally traceable packages. Well log and outcrop locations indicated in Figure 8. 


\section{PARASEQUENCE DESCRIPTIONS}

Individual lithofacies are described in terms of their geographic distribution, color, bedding, composition, texture, fossils and sedimentary structures (c.f. Reading, 1986). Assemblages of facies in the Bluefield Formation occur in cyclic, coarseningupward, meter-scale parasequences (cf. Van Wagoner et al.,1990) which are bounded by sharp flooding surfaces, or erosional unconformities (Fig. 7). Each flooding surface records an abrupt increase in water depth as evidenced by a landward shift in facies. Facies between these distinctive bounding surfaces are gradational and conformable, and are considered to be genetically and environmentally related. Describing individual lithofacies in the context of conformable assemblages provides additional evidence which makes environmental interpretation easier than treating each facies in isolation (Reading, 1986). At least 28 parasequences have been identified in the depocenter (Fig. 7), whereas fewer parasequences are developed in the marginal locations.

\section{Parasequence Type "A"}

This assemblage of facies occurs exclusively in the 'upper' Bluefield Formation (Figs. 9, 11), and is confined to the northeastern portion of the study area. In outcrop, the assemblage varies laterally in thickness and character, yet extends for several kilometers in subsurface cross-sections.

A typical vertical profile of this parasequence type is illustrated in Figure 12. Black shale defines the base of the parasequence and averages 0.5 to 1 meter in thickness. The shales are finely laminated and contain siderite nodules, ostracods, and inarticulate brachiopods. Mottled, green to gray discolored zones commonly extend $20-30 \mathrm{~cm}$ below 


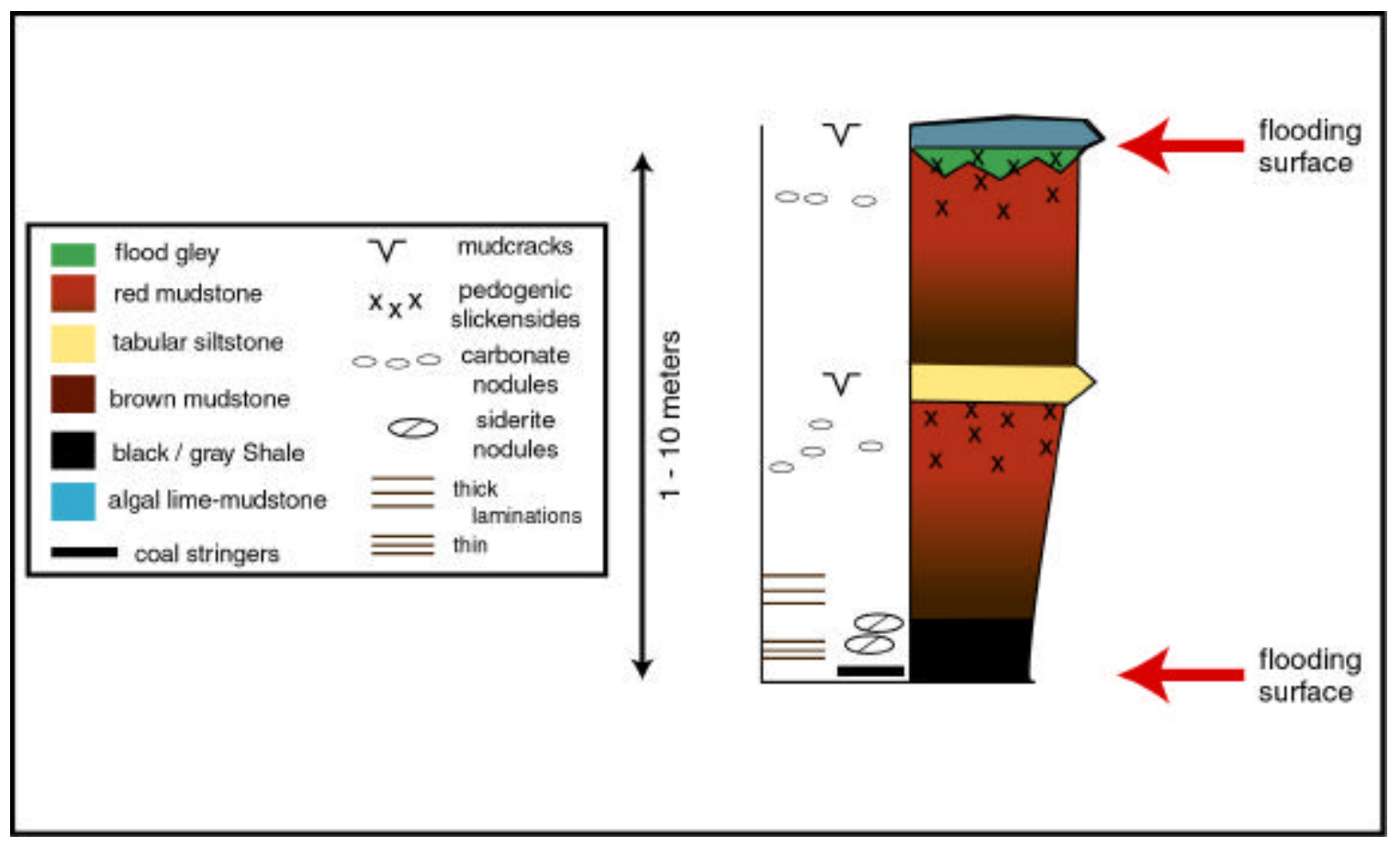

Figure 12: Idealized schematic diagram illustrating parasequence type " $A$ ". This parasequence type is typical of the upper part of the Bluefield Formation, but is not present in the southern portions of the study area.

the sharp base of black shale facies into underlying facies. Thin, discontinuous coal stringers up to $5 \mathrm{~cm}$ in thickness are rarely associated with the mottled zones. In outcrop and borehole gamma ray surveys, the black shale facies exhibits a distinctively 'hot' response that can be traced for several kilometers laterally.

Thinly laminated brown mudstones gradationally overlie the black shale. The brown mudstones are typically less than 1 meter in thickness, and lose distinct laminations where associated with zones of rooting and bioturbation. This facies rarely contains ostracods and root casts. The brown mudstone facies commonly looses distinct bedding where overlain by red mudstones. These thick-bedded mudstones form the uppermost facies of this parasequence, and are the most abundant and distinguishing 


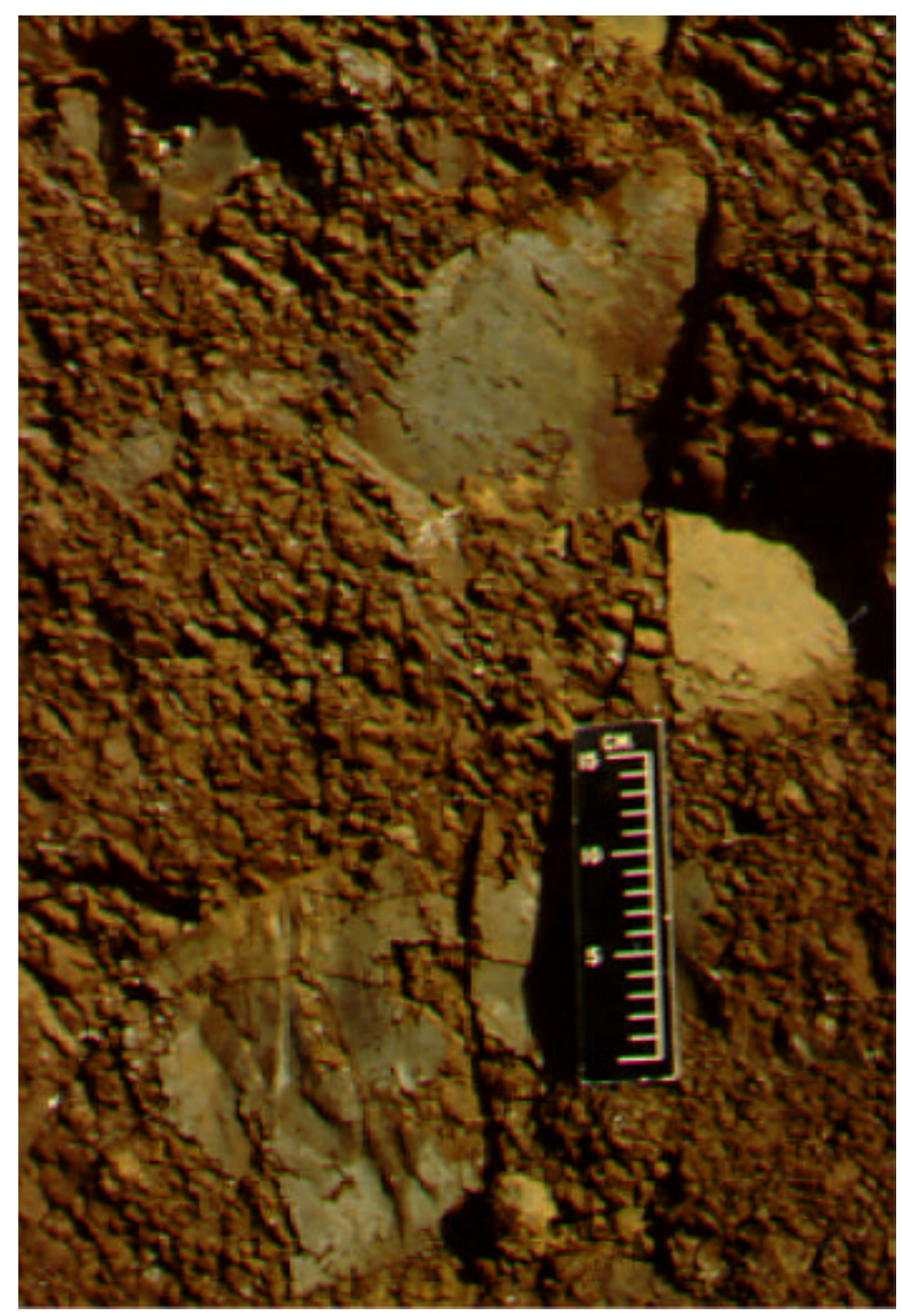

Figure 13: Photograph of red mudstone facies typical of upper Bluefield Formation. Blocky texture, calcareous nodules, halite pseudomorphs, and irregular, shiny slicken-lined surfaces are interpreted to reflect pedogenesis in a semi-arid environment.

feature of the upper Bluefield Formation (Fig. 13). Basal contacts of the red mudstone facies are gradational and are located at the last identifiable bedding or lamination in the underlying facies. The red mudstones have an upward increasing 'hackly' texture, which crumbles into millimeter to centimeter-scale peds when handled. Blocky (angular to subangular) and granular peds are common in thicker beds, whereas platy, flat peds are usually found in thinner units of red mudstone. The red beds range from non-calcareous 
to strongly calcareous. Carbonate-rich horizons often contain abundant calcareous nodules, commonly coalescing into one or more semi-continuous undulating horizons. The mottled red nodular carbonate horizons are devoid of fossils and are commonly rooted. Halite pseudomorphs are commonly preserved within the zones of red mudstone containing platy, flat peds. Randomly oriented, undulatory slickensides crosscut the red mudstone facies and can extend laterally and vertically for over half a meter. Tabular siltstone beds averaging 30 centimeters in thickness rarely occur within the red mudstones. These have sharp bases and assume a mottled reddish-green appearance upwards where in gradational contact with overlying red mudstones. Basal mudcrack casts are commonly present at the bases of siltstone beds. Several repetitions of the tabular siltstone facies and red mudstone facies are commonly stacked in vertical succession, before being sharply terminated by a black shale or lime mudstone of the succeeding parasequence.

Laterally discontinuous, dark gray to mottled-brown beds of carbonate mudstone, measuring 5 to 15 centimeters in thickness rarely cap the red mudstone facies. Basal contacts are sharp and often contain mudcrack casts. Thin section analysis reveals that these carbonates are dominantly muddy algal laminates, with abundant silt-sized quartz grains and plant fragments (Fig. 14). They are heavily bioturbated, with millimeter size, calcite-filled voids that contain fecal pellets and peloids. Despite evidence for heavy bioturbation, the facies is generally unfossiliferous except for the presence of rare ostracods. 


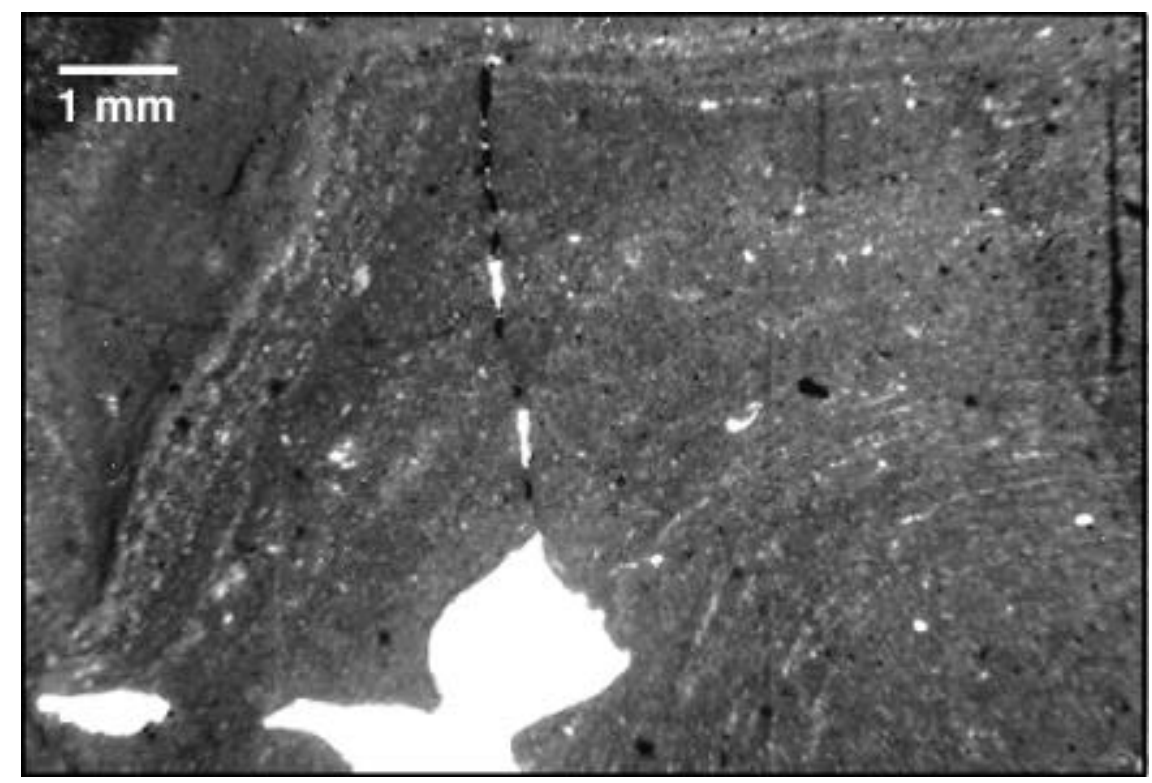

Figure 14: Photomicrograph of carbonate mudstone occasionally present near flooding surfaces of parasequence type 'A'. Facies is generally nonfossiliferous and preserves a cryptic algal structure.

\section{Parasequence Type 'B'}

This assemblage of facies occurs throughout the middle and upper Bluefield Formation, and is developed throughout the study area. Individual parasequences vary between 3 and 6 meters in thickness. A typical vertical profile of this parasequence is illustrated in figure 15. The lower half of this parasequence type consists of thinly to thickly laminated black to gray shale. The shale facies rarely exceed 2 meters in thickness, and are characteristically rich in organic plant material within the lower few centimeters. The organic-rich shale commonly contains discontinuous coal stringers, and less commonly a well defined coal bed, less than 5 centimeters in thickness. Root traces 


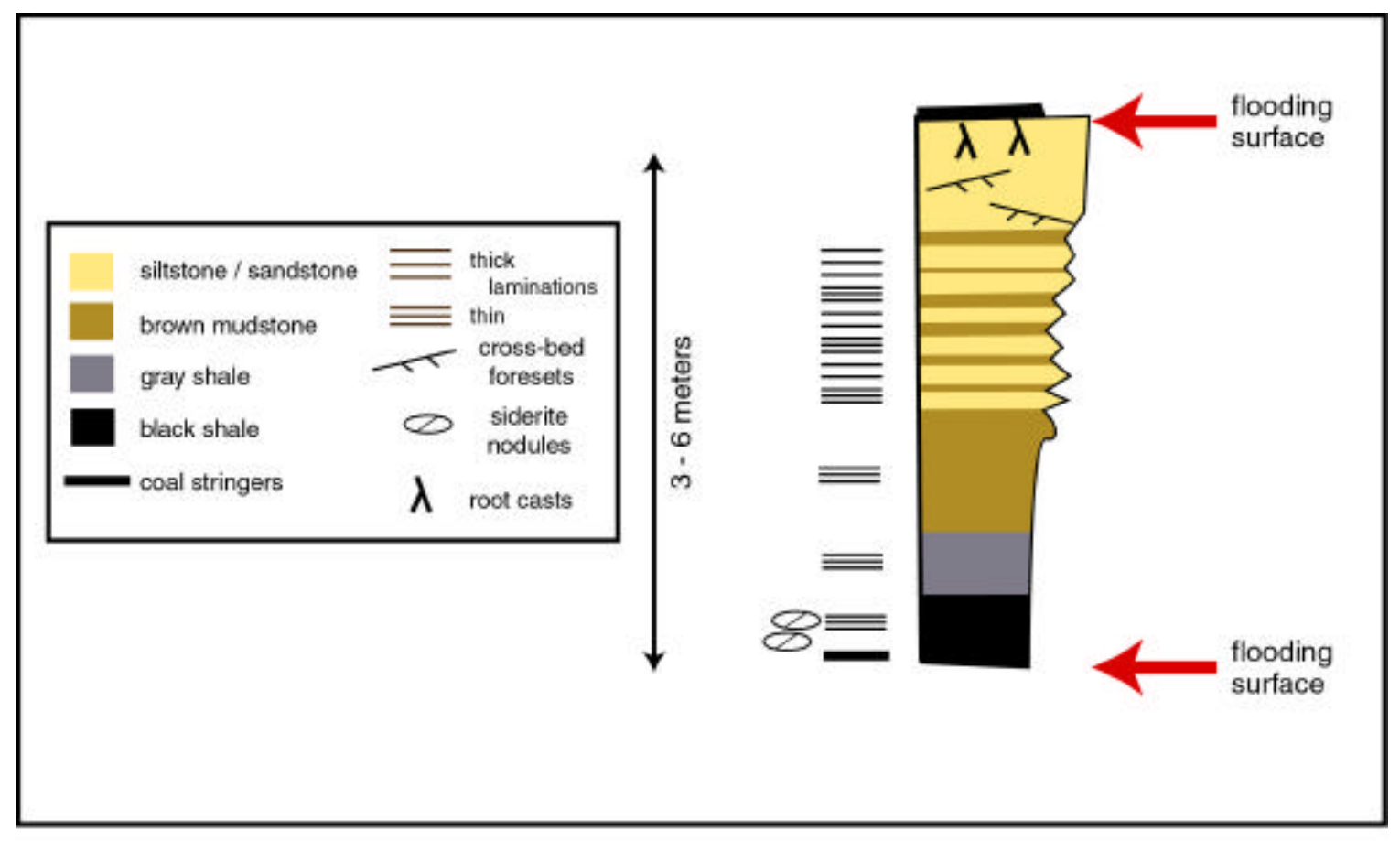

Figure 15: Idealized schematic diagram illustrating parasequence type "B". This parasequence type is typical of the upper part of the Bluefield Formation, and is found throughout the study area. Parasequences of this type in the southern portion of the study area often lack the upper thick bedded, rooted sandstone facies and coal horizons.

and preserved root casts commonly extend up to half a meter into the underlying parasequence. The organic-rich shale grades upward into gray, finely laminated, silty shale with only a few small plant fragments and ostracods. Randomly distributed siderite nodules are common, and sometimes coalesce into semi-continuous layers in this part of the shale facies. Commonly, weathered surfaces of the upper half meter of the gray shale facies express a crude bundling of thick and thin laminations.

The shale facies gradually coarsens upward into rhythmically interbedded very fine-grained sandstone, siltstone and mudstone (Fig. 16). Bedding commonly alternates 


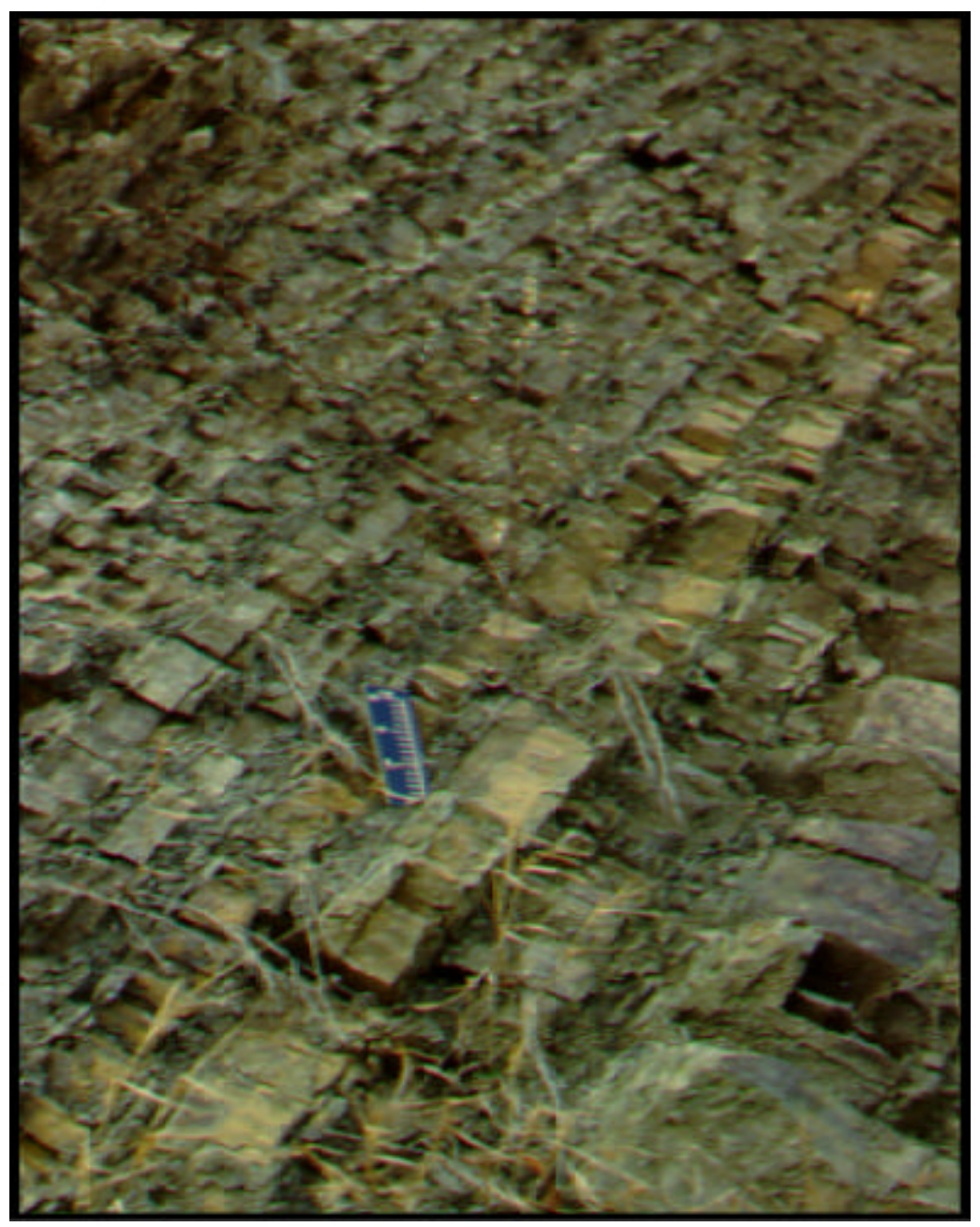

Figure 16: Photograph showing overturned beds of rhythmic facies typical of parasequence type "B". Each siltstone/sandstone and mudstone bed contains bundles of thick and thin laminations suggestive of tidal influence. A high degree of bioturbation commonly results in the amalgamation of several laminations.

every 10-20 centimeters between tabular, very fine-grained sandstone/siltstone, and silty

mudstone. Close examination of the sandstone/siltstone beds reveals alternating thick and thin millimeter-scale, couplets of very fine-grained sandstone/siltstone and mudstone.

Couplets are stacked into $10 \mathrm{~cm}$-thick cycles in which sandstone/siltstone laminations

thicken and thin. The silty mudstones have less distinct sub-millimeter scale silt/mud couplets, which often coalesce into indistinguishable masses due to bioturbation. 
Typically, sub-vertical and horizontal burrows disrupt the delicate laminations.

Generally, the darker, silty mudstones contain large amounts of micaceous and organic material with rare plant fragments up to 2 centimeters in length.

In the southeastern outcrops only, the rhythmically bedded facies grades upward into thickly bedded litharenites. Fine-grained sandstones are well sorted, commonly unstratified with faint ripples and cross-beds, and often contain horizontal and vertical burrows. The upper half-meter of the sandstone facies is commonly extensively rooted, and overlain by a thin gray rooted mudstone with discontinuous shoestring coals or a more distinct 2-4 centimeter thick coal. A green to gray discolored horizon is commonly developed in the upper $5-30 \mathrm{~cm}$ of the parasequence.

\section{Parasequence Type ' $C$ '}

This assemblage of facies occurs in the lower Bluefield Formation throughout the study area. A typical vertical profile of parasequence type 'C' is shown in Figure 14. Facies of this parasequence type contain the most diverse assemblages of fossils and sedimentary structures in the Bluefield Formation. Gamma ray patterns of this facies assemblage can be traced laterally in the subsurface with little thickness variation, reaching a maximum cycle thickness of 15 meters in the northeastern portion of the study area.

The base of cycle type ' $\mathrm{C}$ ' is defined by a sharp contact overlain by brown to greenish gray, bioturbated mudstone. This facies produces a distinctive, hot gamma ray 

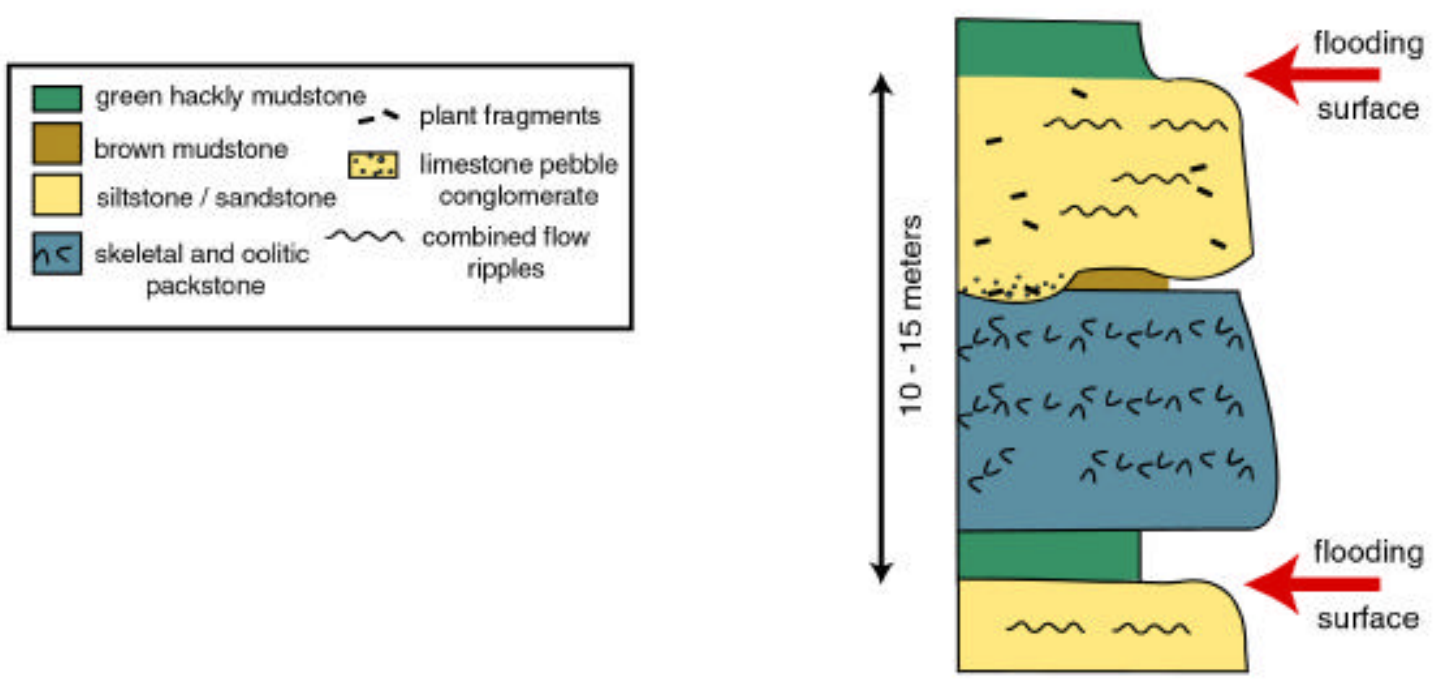

Figure 17: Idealized schematic diagram illustrating parasequence type " $C$ ". This parasequence type is typical of the lower part of the Bluefield Formation. In the southern portion of the study area, parasequences of this type lack the thick-bedded, erosionally based sandstone facies

signature that can be traced throughout the study area. Sharply overlying this facies is 7 10 meters of gray, interlayered, thin-bedded $(2-3 \mathrm{~cm})$ skeletal grainstone, and thin-to thickly bedded $(50-100 \mathrm{~cm})$ packstone and wackestone. Skeletal grains include brachiopods, trilobites, ostracods, foraminifera, mollusks, fenestrate and branching bryozoa, crinoid stems, and radiolaria. Typically, fossils in packstone facies are randomly oriented and poorly sorted with variable degrees of fragmentation, whereas thick beds of wackestone commonly contain larger, whole fossils and occasionally intact fenestral bryozoa (Fig. 18). The bases of the thin grainstone beds rarely exhibit evidence of slight scouring, and in some instances contain well-defined flame structures. A thin (less than 1 meter) brown, laminated non-fossiliferous mudstone may overlie the 


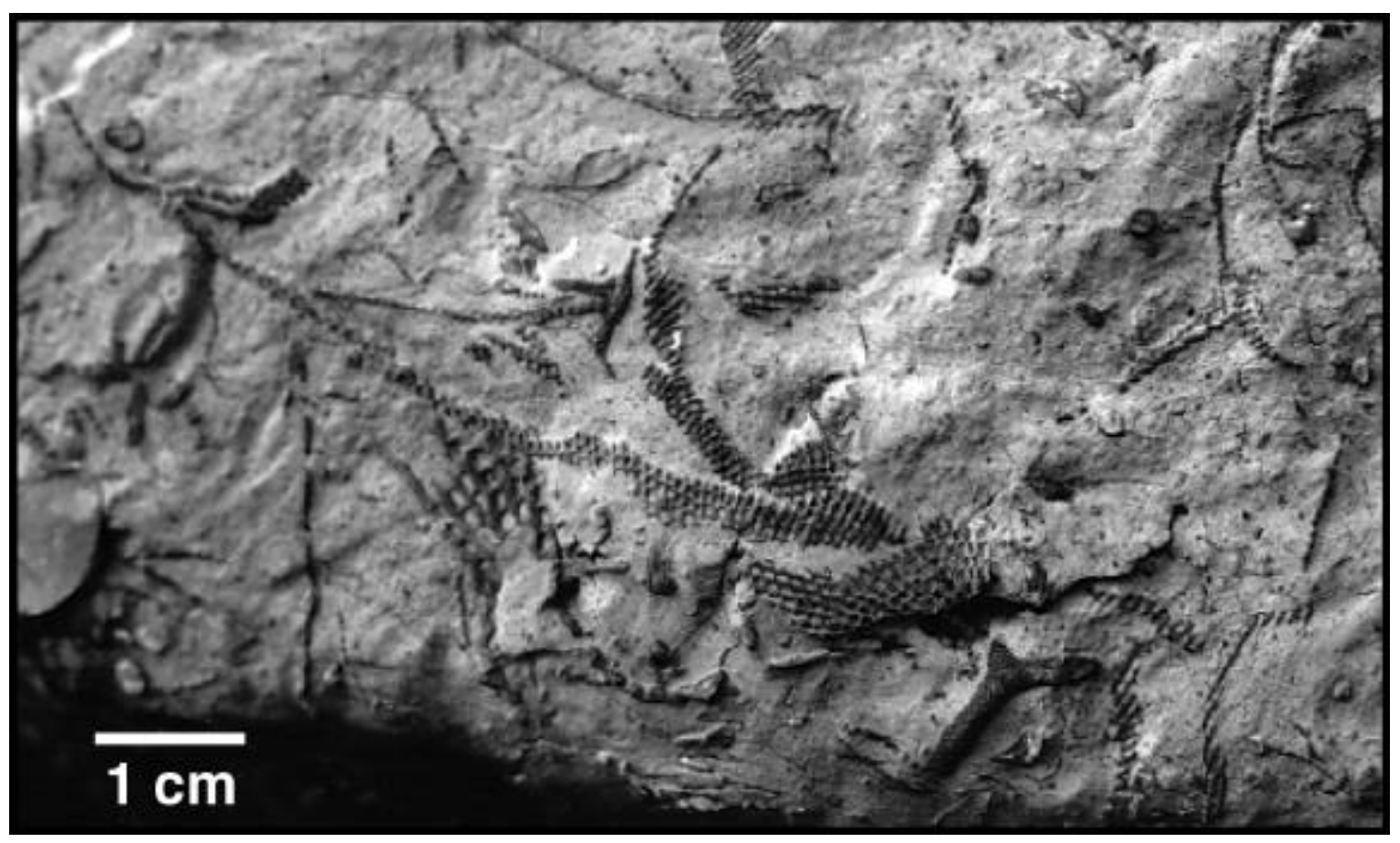

Figure 18: Photograph of skeletal packstone/wackestone facies typical of parasequence type " $C$ ". Skeletal fragments of bryozoa and crinoids suggest open marine conditions. Muddier intervals commonly preserve intact fossils including delicate fenestrate bryozoa. Fossils preserved in packstone intervals are commonly fragmented to a higher degree suggesting relatively calm water conditions were periodically disrupted by storms.

carbonate facies. Unlike the mudstone at the base of the parasequence, this mudstone facies does not produce a distinct gamma ray signature, is relatively unburrowed, and is typically truncated or removed completely in the southeastern outcrops by overlying sandstone/siltstone (Fig. 17).

The fine-grained sandstone/siltstone facies range in thickness from 7 to 10 meters and display an erosional, undulating basal contact. Above the contact, rounded limestone pebbles with diameters of one millimeter or less are intermixed with large plant fragments up to 7 centimeters in length in a thin patchy small-pebble conglomerate. The base of the facies commonly exhibits evidence of scouring such as flute casts, groove marks, and gutter casts. Plant fragments up to 5 centimeters in length are aligned parallel 
to sedimentary structures thoughout the facies. Fragments less than 1 millimeter in length are commonly found in the troughs of ripples with no preferred orientation. Other sedimentary structures found in this facies include combined-flow ripples, trough crossbeds, and load casts with wrinkle marks. Horizontal burrows up to 5 centimeters in length are common throughout most of the facies, and horizontal burrows up to 3 centimeters in diameter and 10 centimeters in length are rarely present on bedding planes. Amphibian trackways are found near the top of this facies, and are the oldest record of a terrestrial vertebrate (Hylopus hamesi) from the eastern United States (Sundberg et al., 1990).

Detailed correlation of regional subsurface and outcrop gamma ray surveys reveal the presence of two sandstone horizons capping this cycle type; these sandstones are located at the top of regional sequence 1. Paleocurrent data from the sandstones (Fig. 19) were gathered in the northeastern portion of the study area (see Appendix A for exact locations, data and restoration procedures). In the lower sandstone, water current directions indicated by flute cast orientations are strongly unimodal to the southwest. Groove casts and current lineations are bimodal-bipolar southwest - northeast. Paleocurrent directions from other sedimentary structures found throughout the sandstone bed are less well defined. Trough cross beds are polymodal, with major current directions to the northwest and the east, and a subordinate mode to the southwest. Symmetrical and straight-crested, form-discordant, combined-flow ripples (Fig. 20), indicate flow to the east with a subordinate mode to the southwest.

Paleocurrent directions for the upper sandstone differ from the lower sandstone (Fig. 19). The upper sandstone also contains a greater amount of carbonaceous material. 
Flute casts found on the basal, erosive contact are unimodal to the southeast.

Plant fragments are approximately aligned with current lineations and indicate north south bimodal-bipolar paleoflow. Most trough cross beds axes are oriented to the north, with subordinate modes to the south and east. Combined-flow ripples indicate flow primarily to the southwest, with subordinate flow to the north and east.

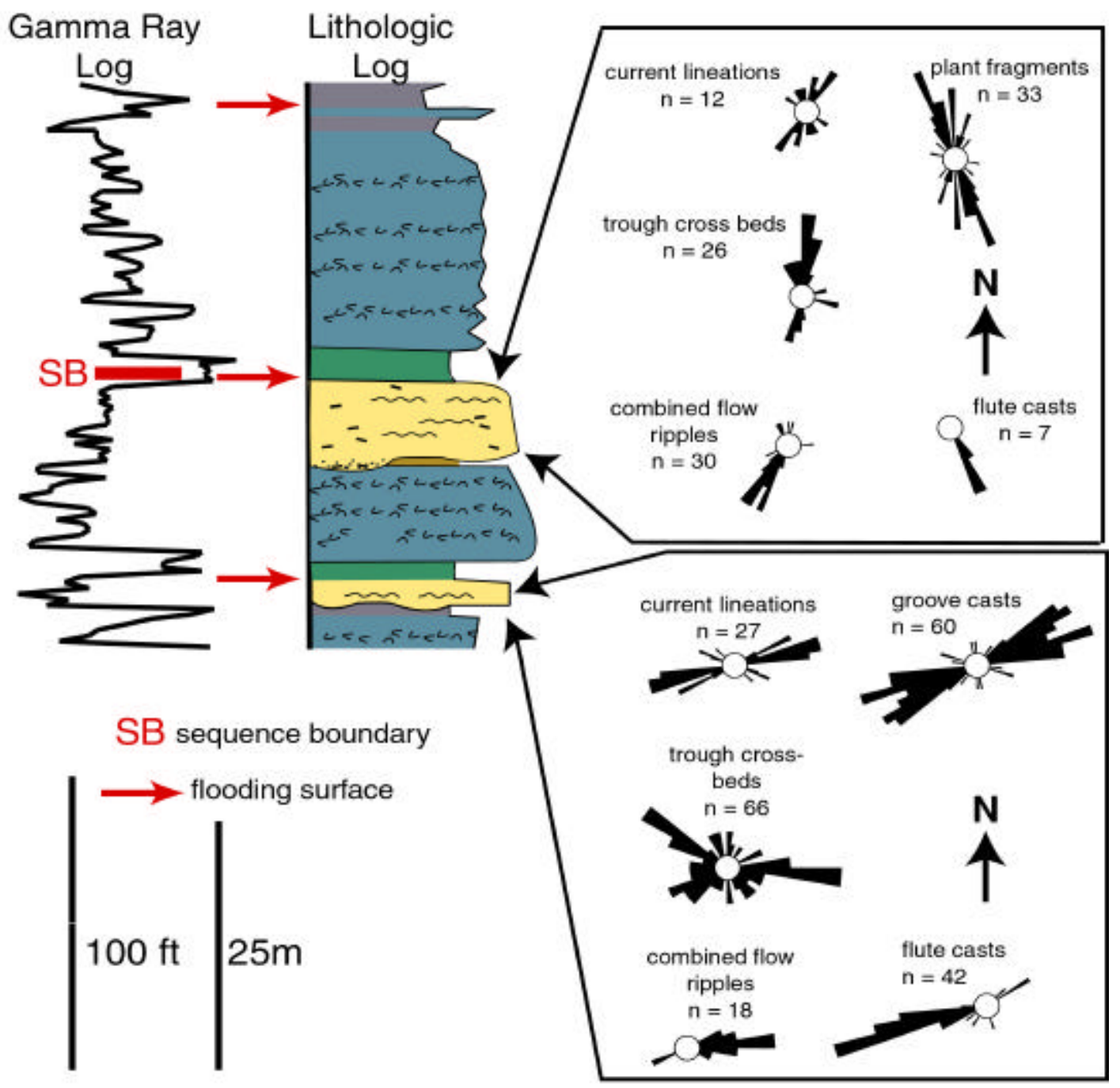

Figure 19: Paleocurrent data from the Oakvale-Glen Lyn area for sedimentary structures in sandstones of parasequence type "C". Also shown is the location of the sandstones with respect to flooding surfaces, and the regionally mappable sequence boundary 2 . 


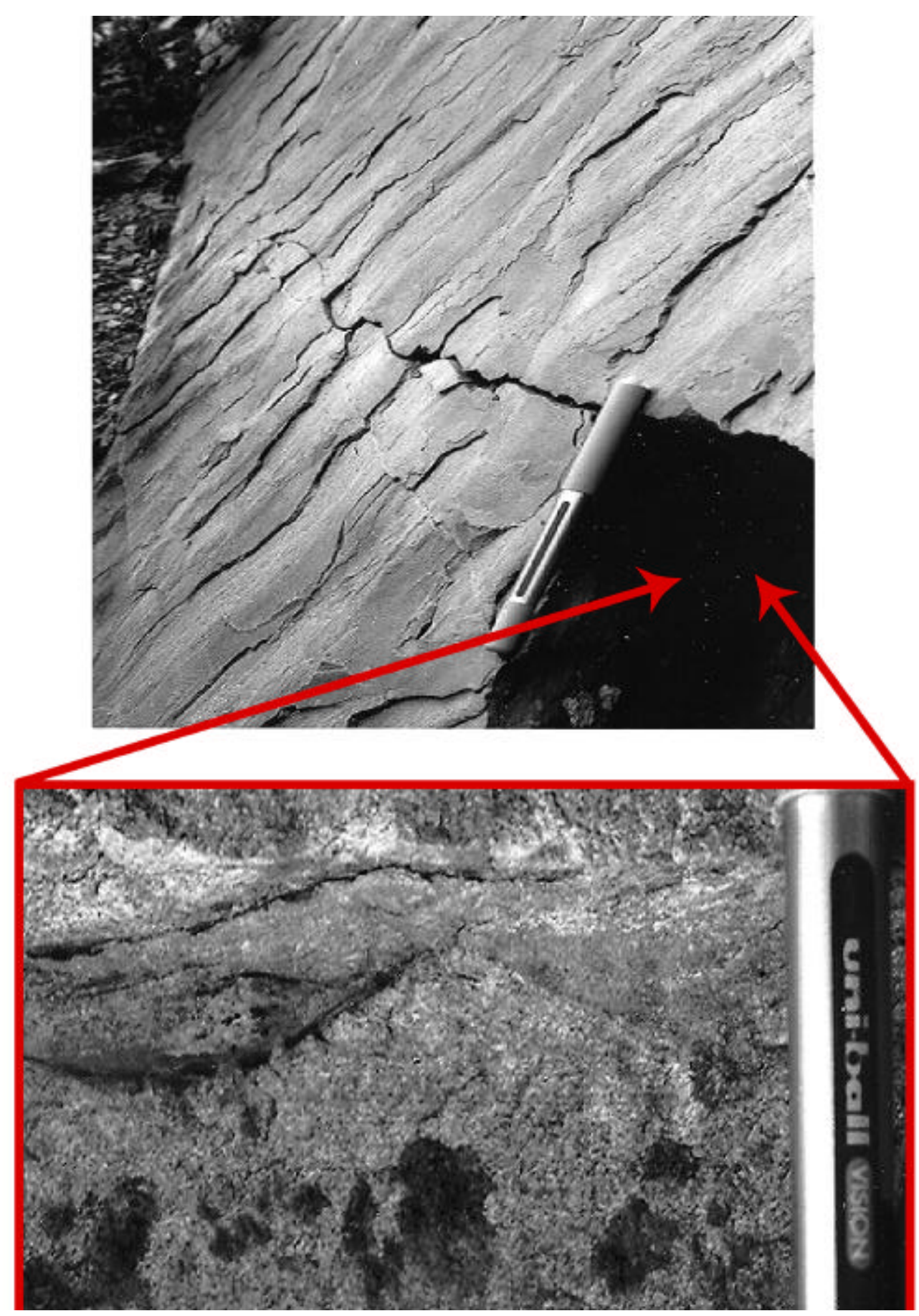

Figure 20: Photograph showing symmetric, straight-crested, form-discordant, combined-flow ripples exposed in overturned sandstone facies of parasequence type "C". Cross sectional view of ripples reveals dominant flow direction (to right of photo). 


\section{Parasequence Type 'D':}

This parasequence type is common in the lower Bluefield Formation and is present throughout the study area. A representative vertical profile of this parasequence type is shown in Figure 21. This assemblage of facies yields an overall 'hot' gamma ray pattern, yet individual facies are rarely distinctive on gamma ray surveys. Thicknesses of individual parasequences range from 15 meters in the northeastern portion of the study area, to less than 3 meters in the southwest.

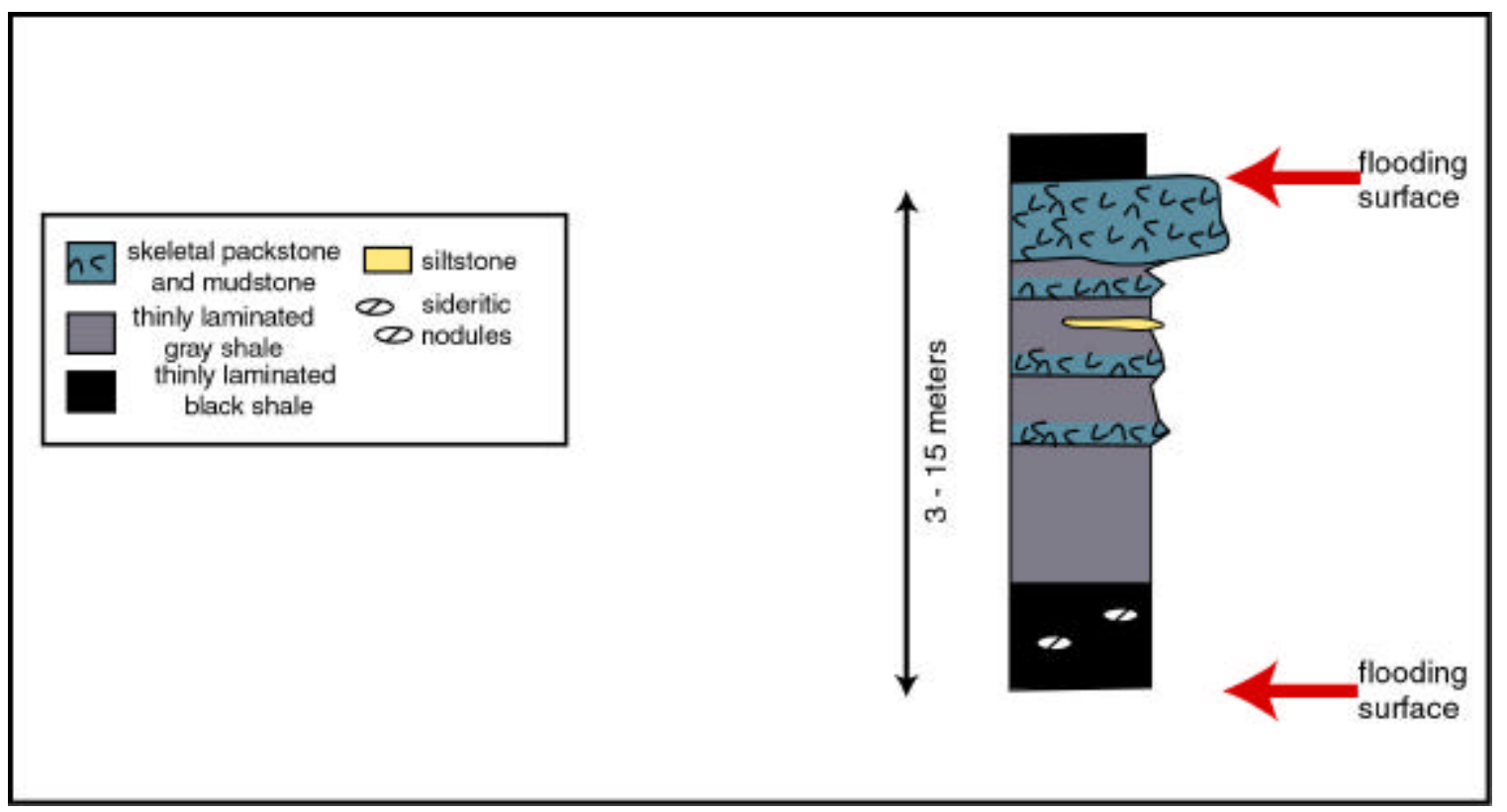

Figure 21: Idealized schematic diagram illustrating parasequence type " $D$ ". This parasequence is found throughout the study area, and is typical of the lower part of the Bluefield Formation.

The base of this parasequence type is defined by black to gray thinly laminated shale. Typically, this facies alone accounts for most of the thickness of this parasequence type. The black shale facies can be subdivided into a lower, noncalcareous zone, and an upper fossiliferous, more calcareous zone. The lower zone is very finely laminated and 
rarely contains more than a few small disarticulate brachiopods. It is characterized by discontinuous horizons of sideritic nodules and semi-continuous thin beds of siliciclastic siltstone. The lower shale rarely exceeds half a meter in thickness and grades upwards into more calcareous shale. This zone is typified by finely laminated gray calcareous shale and mudstone containing several millimeter- to centimeter-thick, discontinuous beds of skeletal packstone that preserve no basal scouring, and grade upward into finely laminated mudstones. The skeletal beds increase in continuity and thickness upwards. Each bed has a sharp base, overlain by skeletal packstone, which, in rare instances, preserves basal flame structures. The packstones commonly contain unsorted fragments of brachiopods, trilobites, ostracods, foraminifera, mollusks, bryozoa, crinoid stems, and intraclasts of rounded silty lime mudstone, and grade upward into mud-supported skeletal wackestone and lime mudstone (Fig. 22). Thin (1-2 cm), discontinuous siltstone lenses occur throughout the upper few meters of the shale facies. Often the parasequences are capped by thick $(0.5-1$ meter $)$ beds of skeletal to oolitic packstone and mudstone or, in rare instances, dolomitic mudstones dominated by intraclasts of rounded silty lime mudstone.

\section{PARASEQUENCE INTERPRETATIONS}

\section{Flooding surfaces}

Flooding surfaces in the upper part of the Bluefield Formation indicate an abrupt shift in facies, and are commonly marked by the sharp contrast of mottled, sub-aerially exposed facies overlain by finely laminated gray to black shales, carbonaceous shales, and/or thin limestones. Greenish-gray discoloration extending several centimeters below 


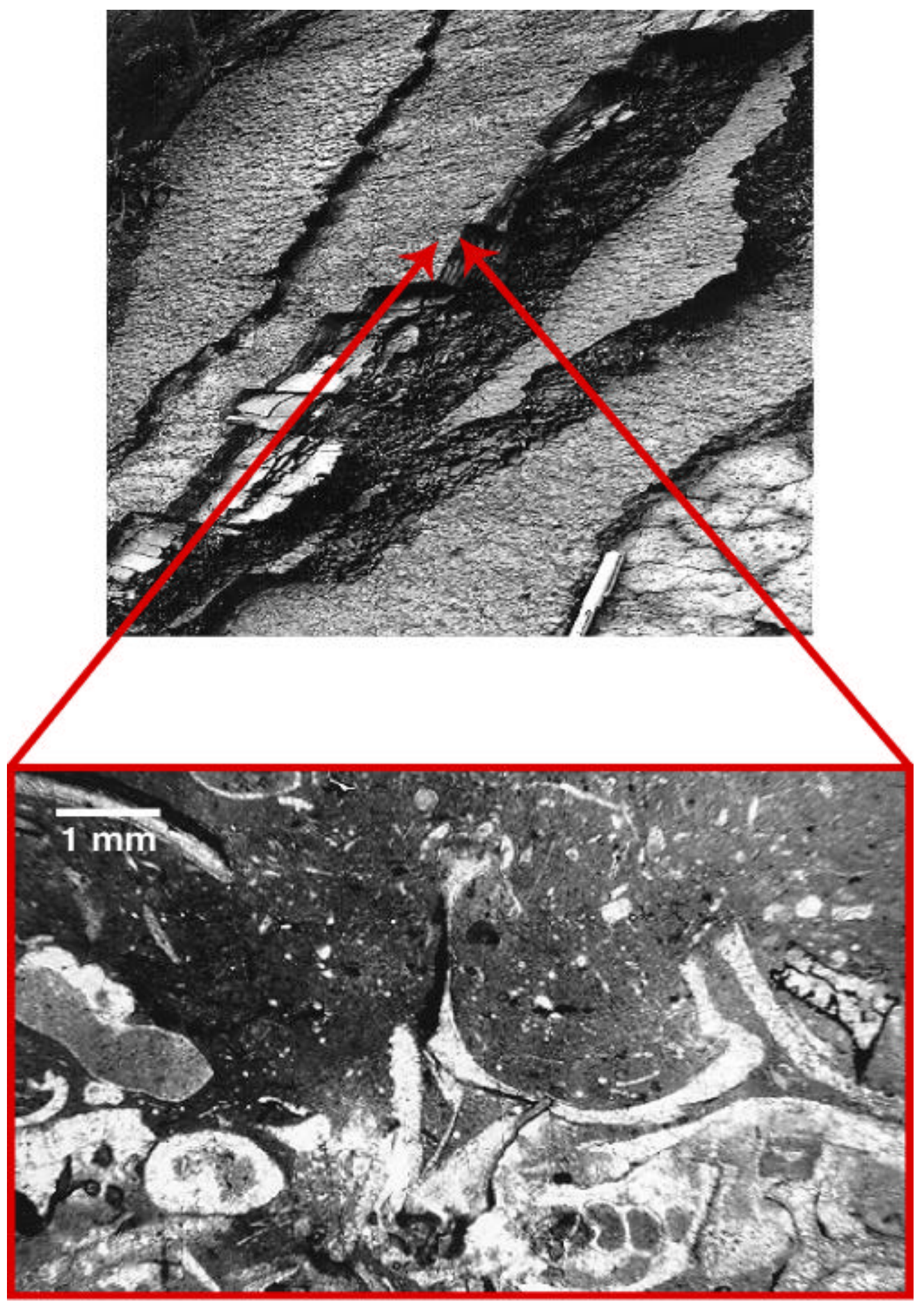

Figure 22: Upper photograph shows overturned carbonate packstone and mudstone facies typical of parasequence type " $D$ ". The facies is dominated by carbonate mudstone and contains several thin beds of skeletal packstones. Lower photomicrograph shows the poor sorting of skeletal material and fining upward trend of each bed. 
the flooding surface is interpreted to represent flood gleying, and to be the result of modification of previously well-drained and exposed sediments in response to a rise in relative sea level (cf. Brown and Kraus, 1981). In some instances, the initial transgression of sea level recorded at the base of parasequences is associated with organic rich horizons, coaly mudstones, or thin mottled, carbonate mudstones. Each of these facies are commonly associated with distinct flood gleys, and are interpreted to result from a change from well-drained to waterlogged, mire conditions.

Several factors control the production and preservation of carbonaceous material in the rock record (Ingram, 1983; Bohacs and Suter, 1997). Production of organic material is largely dependent on a raised groundwater table, accompanied by a low rate of clastic input. Preservation of organic material requires an accommodation rate that approximately equals the accumulation rate of peat, and is aided by a decreased oxygen availability to decomposing organisms associated with the near-surface groundwater table (Frenzel, 1983; Moore, 1989; Bohacs and Suter, 1997).

In the Bluefield Formation, the occurrence of coal and lime mudstone above flooding surfaces that overlie red vertic paleosols suggests a transition from a welldrained, subaerially exposed coastal plain, to temporarily waterlogged conditions with relatively low clastic influx. In coastal plain settings, the position of the ground-water table is controlled eustatically by the position of sea level, and climatically by the relative rates of precipitation and evaporation (Freeze and Cherry, 1979). The elevation of the ground-water table to near the topographic surface may be forced by a climate change, or by relative sea-level rise that can cause the downward flow of water in the sediment profile to cease, resulting in supersaturated conditions (cf. Gardner et al., 1988; Yang et 
al., 1998). This combination of factors created coastal plain mires colonized by peat swamp flora, which quickly filled available accommodation space and spread laterally, creating a thin coal or coaly mudstone horizon. On other portions of the coastal plain where vegetation was less prolific, supersaturated sediments associated with initial transgression temporarily allowed shallow, carbonate lakes to exist on the coastal plain (cf. Boardman, 1989; Collinson, 1996). The thin, discontinuous lime mudstones are interpreted to represent short-lived, restricted fresh-water algal lakes. Continued rise in relative sea-level resulted in the stressing and eventual inundation of the mires and lakes by clastic sediments (cf. Bohacs and Suter 1997).

Flooding surfaces associated with parasequences in the lower Bluefield Formation lack such organic-rich carbonaceous horizons, and gleyed discoloration is not recognized near flooding surfaces. This implies that the tops of parasequences in the lower Bluefield were not subaerially exposed, as was the case in the upper Bluefield Formation.

\section{Parasequence Type 'A'}

Facies within parasequence type 'A' (Fig. 12) record cyclic deposition on a muddy coastal plain. The base of each parasequence is marked by an abrupt landward shift in facies which is interpreted as a flooding surface (cf. Van Wagoner et al., 1990).

Black mudstones above the flooding surface record marine/lagoonal conditions as reflected by the restricted faunal assemblage. The presence of both ostracods and root zones in the overlying brown mudstones suggest that this facies represents a transition from marine to continental environments. The lack of bedding and sedimentary structures in parts of this facies is due to bioturbation and pedogenic modification. 
Overlying thick red mudstones are vertic paleosols interpreted to have formed on a low gradient flood-plain. Red coloration, blocky to angular soil peds, and randomly oriented slickensides with shiny clay coatings are the result of pedogenic processes associated with an environment fluctuating between long wet and dry seasons (Retallack, 1988; Mora et al., 1991; Miller, 1998). Random calcareous nodules are interpreted to represent carbonate accumulation in the soil profile during extended periods of dryness. Nodular pedogenic carbonate and well-developed calcic horizons are most commonly found in modern-day, finely textured soils in semi-arid and seasonal wet-dry climates (Blodgett, 1988). Halite psuedomorphs within red paleosols also suggest an arid to semi-arid paleoenvironment (Tucker, 1982; Retallack, 1988). Intercalated siltstones are interpreted as crevasse splay deposits. Following these episodic flood events, long periods of subaerial exposure facilitated renewed pedogenesis. Some type 'A' parasequences in the Bluefield are dominated by very thick (up to 5 meters), homogeneous vertic paleosols. These likely resulted from the amalgamation of several long-lived episodes of pedogenisis.

This type of parasequence is interpreted to have developed when sedimentation rates exceeded accommodation, resulting in the development of mostly subaerial, coastal plain deposits. These conditions characterized much of the upper Bluefield Formation within the depocenter.

\section{Parasequence Type 'B'}

Parasequence type 'B' (Fig. 15) records deposition of fine-grained sediments in a tidally influenced environment. This assemblage of facies most likely developed in a 
small-scale, prograding, tidally influenced deltaic environment similar to that described by Maguregui and Tyler (1991). The sharp flooding surface that separates the parasequences records initial marine transgression and is marked by black mudstone,

Gray mudstone is interpreted as a restricted lagoonal or low-energy, back-barrier deposit. The presence of siderite nodules and plant fragments indicates reducing conditions in proximity to a source for the plant fragments. A tidal influence during deposition of this facies is suggested by crude bundling of thickly and thinly laminated mudstone couplets. However, the tidal signal is often masked by bioturbation and amalgamation of several muddy laminations. The coarser grain size of overlying interbedded tabular sandstones, siltstones and mudstones provides more convincing evidence of a tidal influence. The alternating thick and thin couplets of sandstone/siltstone and silty mudstone are interpreted as the deposits of dominant and subordinate diurnal tides (cf. De Boer et al., 1989). The thickening and thinning cycles are interpreted as neap-spring-neap tidal bundles (cf. Dalrymple et al., 1991; Archer et. al., 1995). In contrast, the cyclic decimeter-scale bedding may record longer-duration seasonal climatic changes (monsoonal?), as suggested by Miller and Eriksson (1997) for the Pride Shale located stratigraphically higher in the Mississippian section. Sand and silt were supplied to the depositional environment during monsoonal seasons of high fluvial discharge, whereas silt and mud record the inter-monsoonal seasons (Archer et al., 1991). The heavy bioturbation and small total thickness of the rhythmic facies results in preservation of an incomplete and short record of tides. Thus, although tidal rhythmicity is apparent, it is not possible to accurately establish the actual periodicity of laminations. The thickly bedded, fine-grained sandstone facies that gradationally overlie the 
heterolithic facies are interpreted as a tidal sandbar or sandridge (cf. Maguregui and Tyler, 1991). Cross-beds and ripples in the sandstone facies are commonly faint due to rooting related to development of the overlying thin coal facies.

\section{Parasequence Type 'C'}

Parasequence type 'C' (Fig. 17) records tide- and storm-influenced sedimentation in a proximal offshore marine environment. The presence of a diverse assemblage of fossils within the carbonate facies of this parasequence type suggests an open marine environment, whereas overlying sandstones and siltstones preserve sedimentary structures indicative of a tidal influence. Flooding surfaces within this parasequence type have no associated gleyed or carbonaceous horizons, and are overlain by greenish-gray, bioturbated mudstone lacking evidence of subaerial exposure. Overlying carbonate facies of interlayered skeletal grainstone, packstone, and wackestone indicate a shoreward shift in depositional environments which temporarily prevented clastic accumulation in the area. Filter feeding organisms (crinoids and fenestrate bryozoa) in the carbonate facies confirm that clastic input was low, allowing for the formation of laterally extensive sheet-like skeletal carbonate facies (cf. Humphreville, 1981;

Simonsen, 1981; Kopaska-Merkel et al., 1998). The abundance of carbonate mud, and the large intact growth preservation of many large fenestrate bryozoa, suggest low-energy conditions with minimal wave influence below normal wave base. However, several beds of sharp-based packstones composed of skeletal fragments suggest the periodic occurrence of storms that temporarily lowered wave base. Each storm event caused the intermixing of skeletal fragment packstones with lower energy mud dominated 
carbonates. The abrupt to gradational superposition of non-calcareous muds suggests a rapid influx of predominantly storm-derived clastics that buried the carbonate facies. This siliciclastic mudstone facies is interpreted to represent a low-energy, pro-deltaic deposit shoreward of the carbonate belt (cf. Miall, 1984).

Truncation or removal of the mudstone along a sharp, undulating erosional contact overlain by a thin, small-pebble conglomerate lag (Fig. 17) is interpreted to reflect a large storm event. Evidence for storm-generated erosion is found in the suite of scour structures found on the undulating contact. Flute marks, groove casts, and gutter casts at the base of the two sandstone beds record unidirectional offshore flows. Although some discrepancies exist between directions of ancient and modern stormgenerated sedimentary structures (i.e. shore perpendicular turbidity currents or shore parallel to oblique geostrophic flows), scour structures such as tool marks are most commonly oriented perpendicular to shorelines (e.g. Bridges, 1972; Walker, 1984; Duke, 1990). Structures found on erosional surfaces indicate that scouring by storm-surge ebb currents flowed southeast-southwest (Fig. 19) suggesting that the paleoshoreline was oriented roughly northwest-southeast.

Sandstone facies above the erosional scours are interpreted to be the result of infilling of a storm-generated scour by a near-shore tidal sandbar. The sandstone facies differs from ancient storm-generated deposits in that it lacks hummocky cross stratification (cf. Duke, 1990). Rather, the presence of bimodal-bipolar paleocurrent patterns suggests that the sandstone facies accumulated under the influence of tides (cf. Duke and Prave, 1991). The presence of amphibian trackways and plant fragments in the upper sandstone (Fig. 19) also suggests a tidal-flat setting (Humphreville, 1981). 
Parasequence type "C" is considered to reflect upward shallowing from a storminfluenced, proximal offshore to a tide-dominated nearshore setting (cf. Buising et al., 1996).

\section{Parasequence Type ' $D$ '}

Parasequence type 'D' (Fig 21) is interpreted as the most distal parasequence recognized in the Bluefield Formation. The effects of storms that periodically disrupted the Bluefield coastline dominate this shallow-marine parasequence.

Thinly laminated black to gray shale containing siderite nodules that sharply overlies the non-erosive flooding surface is interpreted as a hemipelagic offshore shelf deposit (Vera and Molina, 1998). Gradationally overlying calcareous mudstone reflects progressive shoaling into a carbonate producing environment. Intercalated skeletal packstones and wackestones are related to episodic storm-generated turbidity currents. Post-turbidity current suspension fallout produced the thinly laminated carbonate mudstone overlying each thin skeletal bed (Molina et al., 1997). Thicker skeletal packstone beds $(10-20 \mathrm{~cm})$ higher in the parasequence, with their evidence of slight scouring and rare flame structures, suggest rapid deposition of the skeletal material on a highly porous, unlithified mudstone substrate (Collinson and Thompson, 1989). Progradational outbuilding of nearshore over offshore environments is reflected by thickbedded sheet carbonate facies which commonly caps parasequences of this type (Vera and Molina, 1998). 


\section{SPATIAL AND TEMPORAL RELATIONSHIPS OF PARASEQUENCES}

Based on an understanding of the depositional environments represented in each parasequence, it is possible to develop a paleoenvironmental model which accounts for the spatial relationships of parasequences observed in the field. Figure 23 is a threedimensional schematic diagram which illustrates the spatial transition from a proximal fine-grained coastal-plain environment to subtidal to open-marine environments in the northeastern outcrops, and shows the inferred relative positions of each parasequence type. Stacking of facies within parasequences is attributed mainly to progradation with a limited amount of aggradation. No scale is implied in this diagram since the main point is to show the inter-relationships of each environment.

Areas dominated by vertic paleosols (in red) typify the upper coastal plain, and reflect well-drained conditions in a semi-arid environment. The stacking of 1-3 vertic paleosol horizons within a coastal plain sequence is likely the result of monsoonal or storm-surge flooding. Flood events periodically inundated the coastal plain for short periods of time, depositing layers of new sediment and interrupting pedogenic development. Much of the diagram illustrates a tide-dominated delta (yellow) and its 
pro-deltaic distal settings. Rhythmically interlayered mudstone and fine siltstone typify the distal deltaic environments, whereas sandstone/siltstone-mudstone tidal rhythmites characterize the proximal delta. The latter are inferred to have developed on elongate tidal ridges of an upper delta plain which prograded over the distal deltaic facies. Seawards of the majority of the prodeltaic siliciclastics, carbonate skeletal and mud forming communities thrived in relatively calm waters free of siliciclastic input. Most 


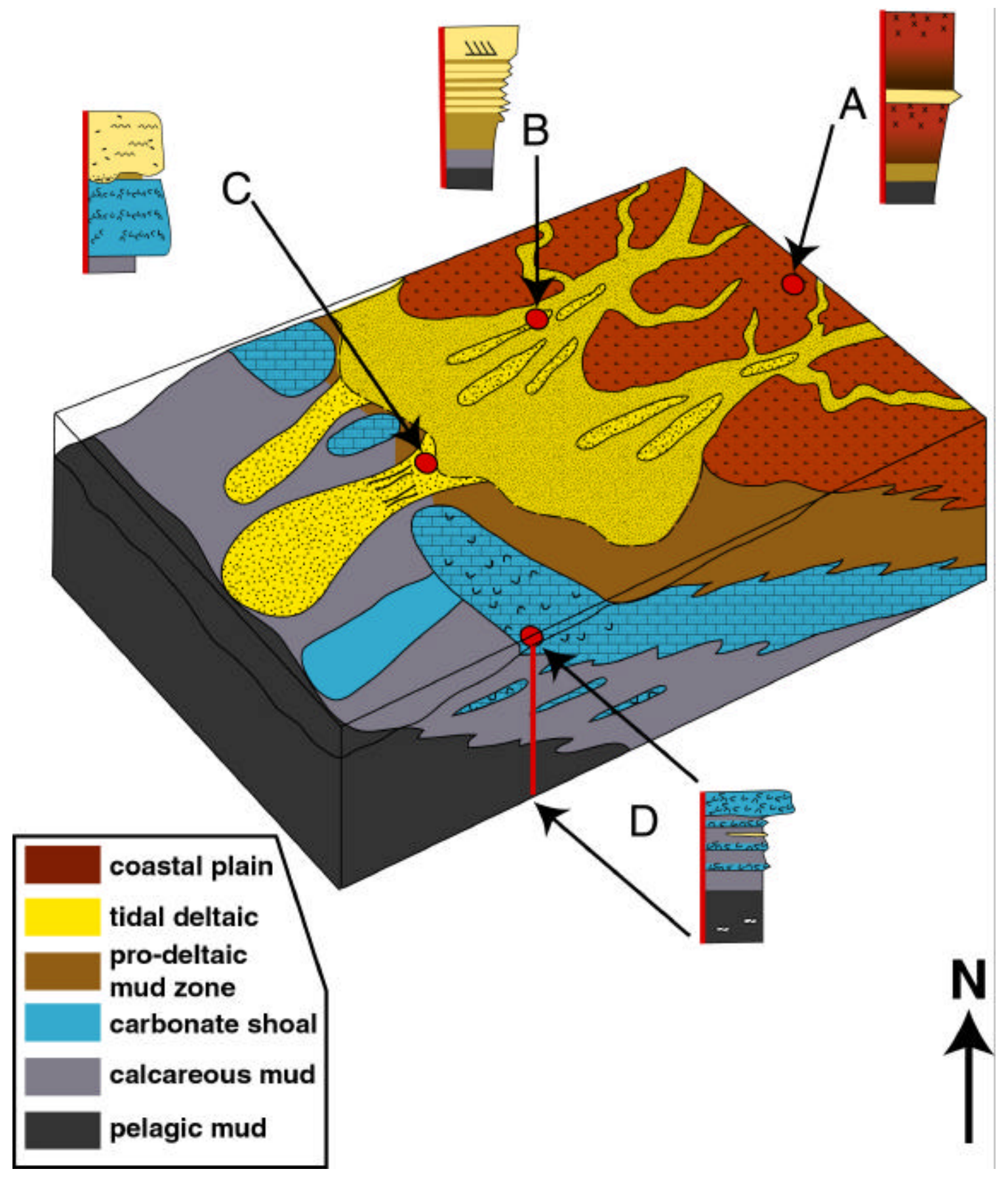

Figure 23: Three-dimensional depositional model showing the spatial relationships of semi-arid coastal-plain and open-marine facies. Vertical sections show stacking of facies in typical parasequences (A-D) resulting from progradation/aggradation. No horizontal scale implied. Parasequences record 2-10 meters of deposition. 
carbonate facies contain large amounts of calcareous mud indicating that fair- weather processes were not sufficient to winnow excess muds from the area.

Storm reworking is reflected in the common occurrence of skeletal packstones containing far less calcareous mud than surrounding lime wackestones. In deeper water environments, turbidity currents related to storm surge created thin skeletal hash beds interbedded with calcareous mudstone. Progradation in this environment is reflected in the upward thickening of successive storm beds.

Storm-surge currents also affected offshore transport of siliciclastic sediment. Erosional scour structures at the base of some marine sandstones are interpreted to reflect storm-surge ebb flows oriented perpendicular to paleo-shoreline. The turbidity currents eroded into and buried carbonate-producing environments. Following deposition, sands were reworked by tidal currents. The thin siltstones present in the deeper water facies may represent the distal expression of the storm-surge turbidity currents.

Following progradational outbuilding, parasequences were drowned in response to a relative rise in sea level (Fig. 24). In the distal, open-marine portions of the basin, flooding resulted in hemipelagic sedimentation, which interrupted production of the skeletal limestone banks. The most dramatic changes occurred on the coastal plain, where peat swamps and shallow carbonate lakes developed during the early stages of relative sea-level rise. Since the position of the groundwater table is controlled by both the ratio of precipitation to evaporation and sea level (Freeze and Cherry, 1979), it is difficult to determine if the presence of the coals and non-marine carbonates records a climatic change to more humid conditions, or reflects a rise of relative sea level. 


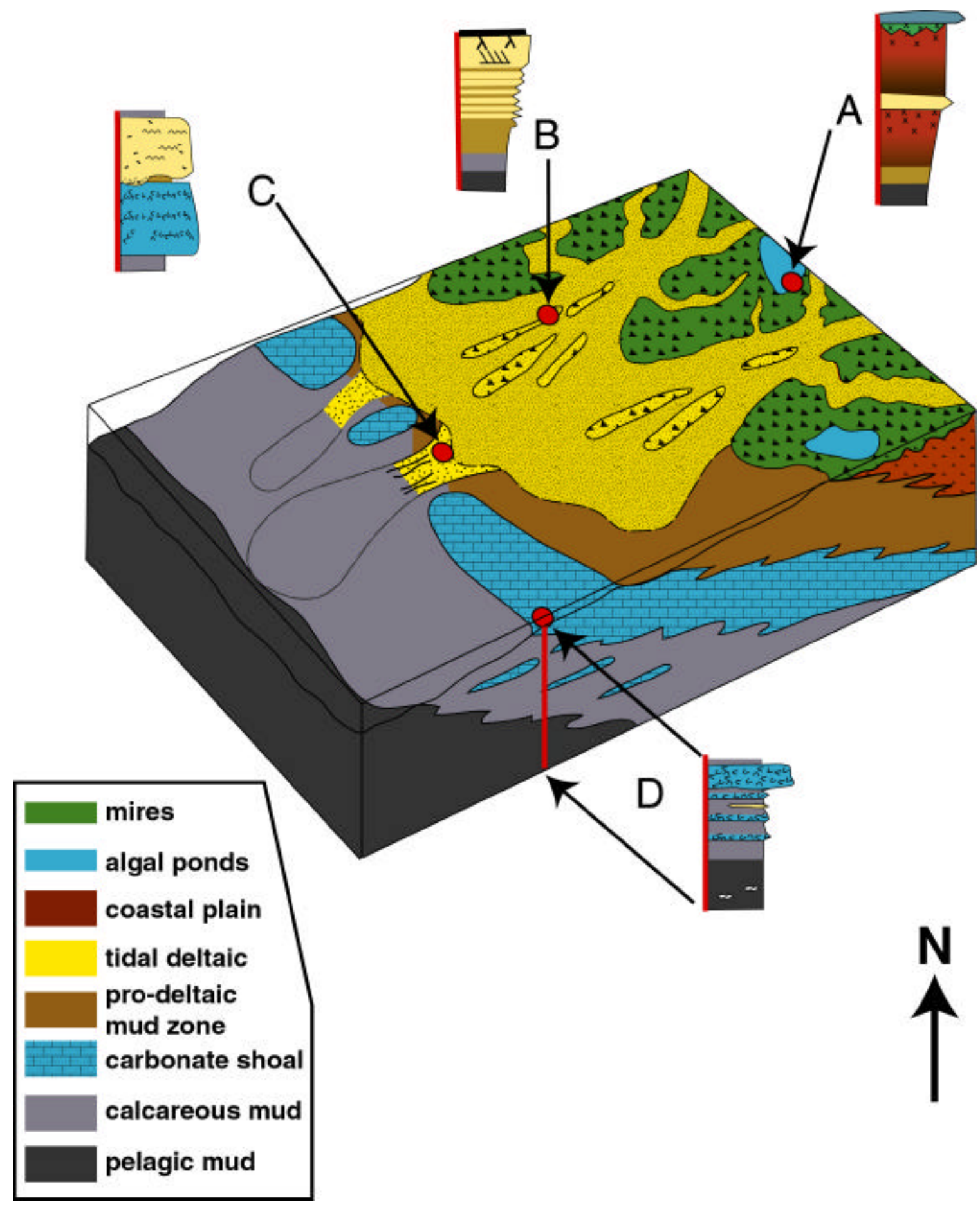

Figure 24: Diagram illustrating the common sedimentary features that developed during initial transgression. The most dramatic changes involved the development of peat and shallow algal carbonate lakes on the water-logged coastal plain. Vertical sections show the typical features of transgression as they would be displayed in outcrop. No horizontal scale implied. 
However, the dramatic shift of facies above parasequence flooding surfaces, and the occurrence of coals surrounded by facies suggestive of an arid to semi-arid climate (as in parasequence type 'A'), seem to suggest that coal formation within the parasequences was controlled by the position and rate of rise of sea level. Figure 24 illustrates the development of coals due to a relatively slow rate of sea-level rise. This condition raised the groundwater-table in the upper coastal plain, transforming previously well-drained vertic paleosols into poorly drained bogs. Above a critical rate of relative sea-level rise, accommodation space would be created faster than coals could develop and the mires would be inundated with salt water. Coastal plain parasequences that do not contain either coals or lacustrine limestones near flooding surfaces are interpreted to have experienced more rapid rates of initial rise in relative sea-level. Following a relative rise in sea-level and drowning of the depositional interface, progradation-aggradation resumed, leading to stacking of parasequences (Fig. 25).

\section{INCISED-VALLEY SANDSTONE FACIES}

\section{Description}

Lenticular sandstone bodies define the bases of the regional, upper siliciclasticdominated Bluefield sequences (3 and 4) throughout the study area, except at the northeastern locations (Figs. 9 and 11). These sandstones have very low and blockshaped gamma ray signatures, and vary from less than a meter to greater than 20 meters in thickness. Subsurface cross-sections reveal that these sandstones locally are incised up to 15 meters into underlying strata that consist mostly of type B parasequences. Outcrop exposure of the Bluefield Formation in the southwestern portion of the study area 


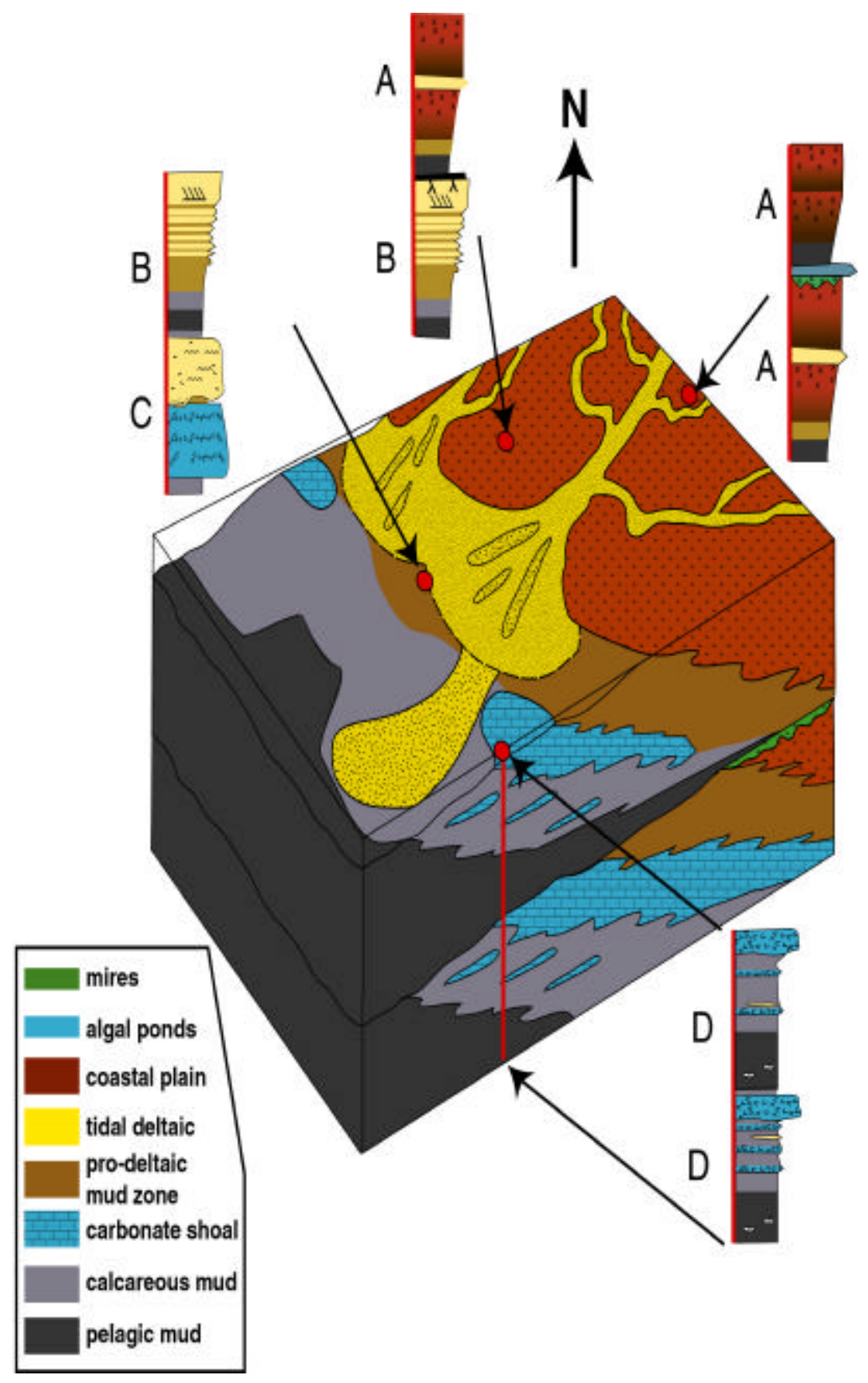

Figure 25: Three-dimensional block diagram illustrating the parasequence stacking patterns related to two periods of progradation/aggradation interrupted by a transgression. No horizontal scale implied. Parasequences (A-D) record 2-10 meters of deposition. 
confirms the incised-channel geometry of the sandstones expressed on well log cross sections. Up to 3 meters of local incision is displayed at the Jenkins, Kentucky outcrop (Fig. 26). A high-resolution, hand-held gamma ray survey of this outcrop allowed for the incised channel sandstones to be confidently differentiated from other sandstones in the subsurface (Fig. 27).

Bases of the incised-valley fills are defined by up to half a meter of gray, hummocky, unstratified, quartz-shale pebble conglomerate. The conglomerate horizons are typically highly carbonaceous, containing plant fragments up to 3 centimeters in length, and thin discontinuous coal stringers. Several meters of nested sandstone channels, characterized by large-scale cross beds, overlie the basal conglomerate or locally rest directly on the basal erosional surface. Typically, toesets of cross beds are defined by lag deposits of rounded quartz pebbles 2-3 millimeters in diameter, and crossbed foresets are commonly graded. Irregularly shaped coal intraclasts are commonly found throughout the cross-bedded sandstone facies. The incised-channel sandstone bodies are either in sharp contact with overlying finely laminated to thinly bedded gray shale, or in gradational contact with flaser-bedded sandstone/siltstone-mudstone (Beek and Koster, 1972). These fine-grained facies are typically less than two meters in thickness.

\section{Interpretation}

The erosionally based sandstone bodies are interpreted as braided-fluvial to tidally-influenced estuarine incised-valley fills. Incision can be the result of progressively increasing discharge due to climatic change, capture of another channel, or 


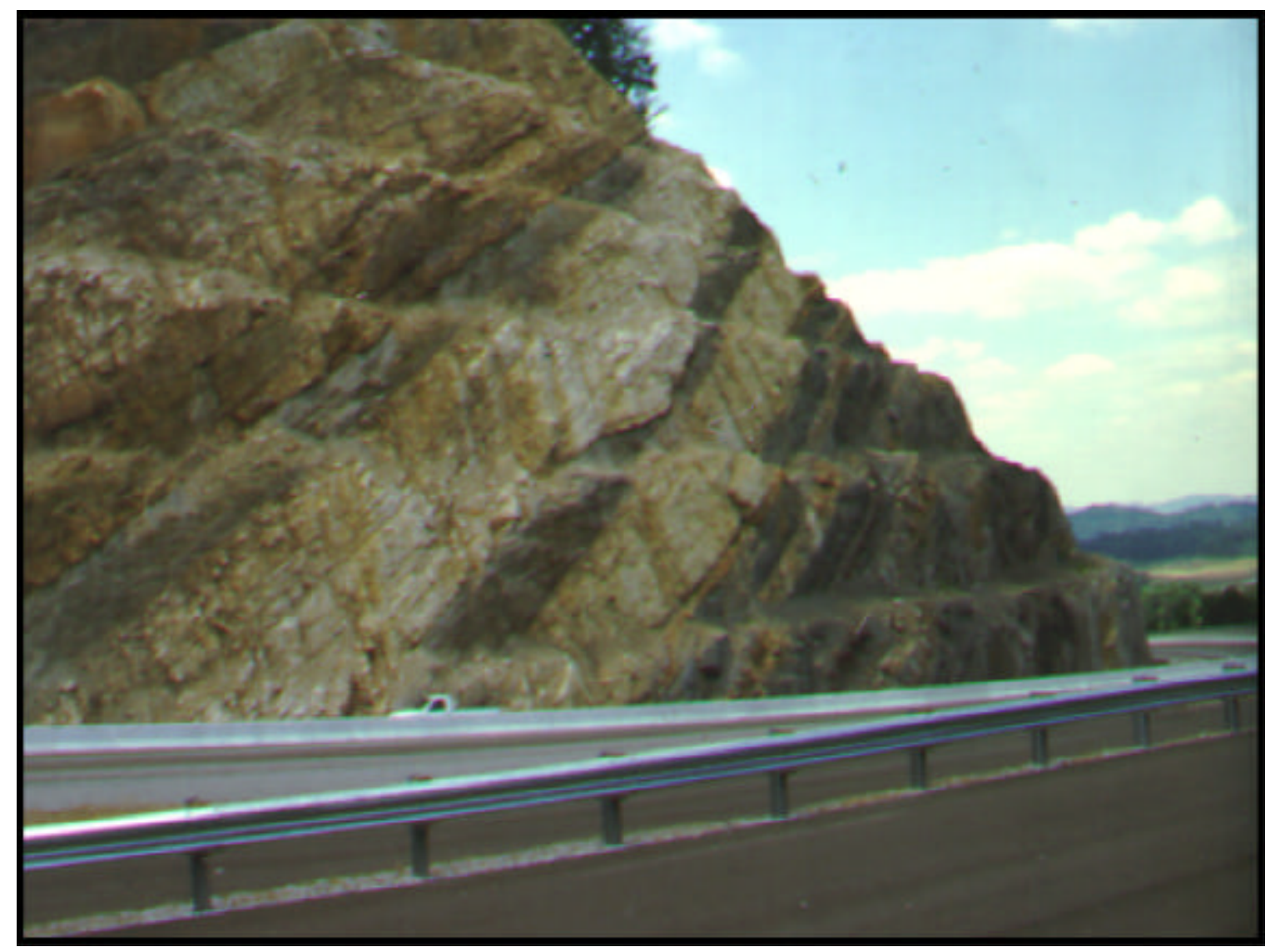

Figure 26: Photograph of Jenkins, Kentucky exposure shows channel sandstones to incise up to three meters locally. Note white truck in lower left edge of photo for scale. 


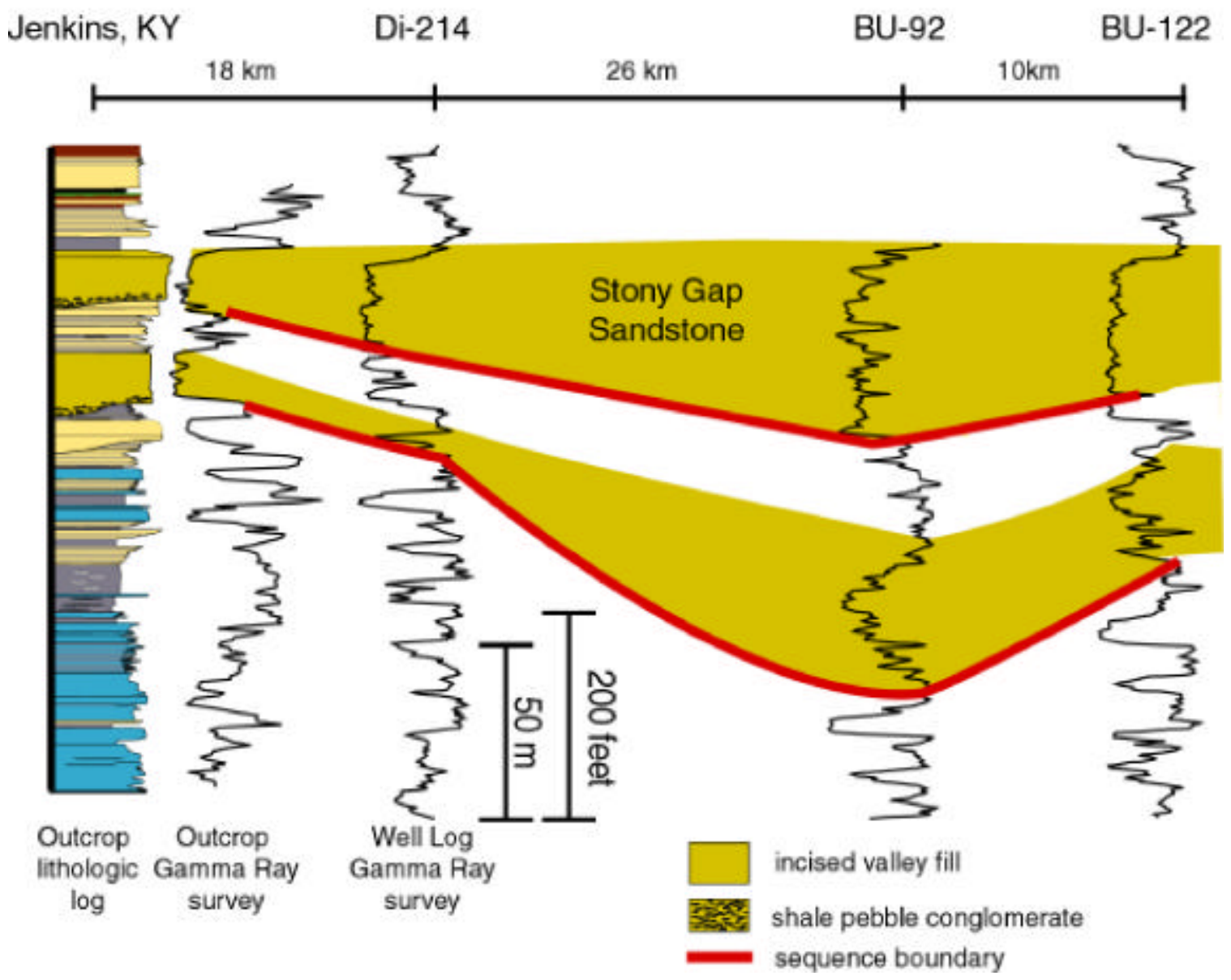

Figure 27: Subsurface cross-section correlated into outcrop near Jenkins, Kentucky with the aid of hand held gamma-ray survey. Distances between well logs are compressed to show the channelized geometry and lateral extent of sequence-bounding incised valley fills. In addition to the incisedvalley fills, the Jenkins outcrop section also contains parasequence types B, C and D. Locations of wells indicated in Figure 8.

lowering of base level (cf. Collinson, 1996). The basal conglomerates and nested sandstone channels overlying the erosional disconformity are consistent with a coarsegrained braided fluvial system which aggraded and backstepped up the valley in response to a relative rise of base level (Zaitlin et al., 1994; Reading and Collinson, 1996). Thin coal stringers throughout the fluvial conglomerate-sandstone facies are interpreted as rip- 
ups of valley floor coals that formed during relative sea level lowstand. Lowstand coals form in erosional valleys primarily due to the process of groundwater sapping (Bohacs and Suter, 1997). The subordinate flaser-bedded facies that cap the incised-valley fills are interpreted as tidal deposits (Cotter and Driese, 1998)

\section{SEQUENCE STRATIGRAPHIC HIERHARCHY}

\section{Composite Sequences}

The Bluefield Formation represents a thick composite sequence consisting of four regionally extensive sequences (cf. Mitchum and Van Wagoner, 1991). The base of the composite sequence is defined by a thick shale-dominated sequence (sequence 1), and the top by a regional unconformity (Fig. 9). Vail et al. (1991) have argued that the duration of composite sequences is in the range of $0.5-3$ million years. Available age constraints give a duration of 3 million years for the composite sequence making up the Bluefield Formation.

The origin of $3^{\text {rd }}$ order composite sequences is controversial. Many workers have attributed composite $\left(3^{\text {rd }}\right.$ order) sequences to eustasy (e.g. Mitchum and Van Wagoner, 1991; Schwanns, 1995). The biostratigraphic equivalence of the study interval to the Glen Dean unconformity-bound $3^{\text {rd }}$ order sequence (Ross and Ross, 1988) in the Chesterian midcontinental type section (Butts, 1933) suggests that deposition of the two composite sequences may have been synchronous. The possibility that the two composite sequences and unconformities formed at the same time, in two separate basins, favors a eustatic control on their development. However, synchronous deposition of composite sequences in neighboring basins can also be explained as the interaction of 
flexural loading and stress variations in the lithosphere (e.g. Quinlan and Beaumont, 1984; Cloetingh, 1988). The distinctly wedge-shaped geometry of the study interval (Figs. 9, 10), as well as the Mauch Chunk Group as a whole (Fig. 3) indicates that the depocenter of the basin near the present Alleghenian thrust front experienced much greater overall accommodation than the basin margin to the west. Thus, the large-scale stratal patterns within the Mauch Chunk Group were likely controlled by tectonically driven subsidence.

Regional tectonic controls such as flexural loading and forebulge migration (Ettensohn, 1994) inadequately address the observation made by Ross and Ross (1988) that composite sequences within the mid-continent are recognizable worldwide. A global, tectono-eustatic control such as the sea-level fluctuations associated with varied sea-floor spreading rates (Harrison, 1990) may more adequately explain the temporal equivalence of the Bluefield and mid-continent Glen Dean composite sequences.

\section{$4^{\text {th }}$ Order Depositional Sequences}

The $4^{\text {th }}$ order sequences in the Bluefield Formation comprise systems tracts of the composite sequence (cf. Vail et al., 1977; Mitchum and Van Wagoner; 1991). Sequence 1 , and the lower half of sequence 2 represent the transgressive systems tract of the composite sequence. The regionally extensive gray-black shale in the middle of sequence 2, (Figs. 9, 11) is interpreted as the maximum flood deposit of the composite sequence, whereas the remainder of sequence 2 and sequences 3 and 4 make up the highstand systems tract. 
Dividing the total time of 3 million years equally among the 4 sequences yields an approximate average duration of 750 k.y. per regional sequence. This technically equates with the $3^{\text {rd }}$ order sequences of Vail et al. (1991). However, this age discrepancy is very likely related to the poor age constraints for Paleozoic siliciclastic rocks of the Appalachian Basin. Each $4^{\text {th }}$ order sequence is composed of genetically related strata, is bounded by erosional unconformities and correlative conformities or regional flooding surfaces, is internally conformable, and is composed of distinct parasequences. These criteria are consistent with the definition of $4^{\text {th }}$ order $(0.8-0.5$ million years $)$, highfrequency depositional sequences (Mitchum and Van Wagoner, 1991; Vail et al., 1991; Van Wagoner, 1995).

Although controversial, many Carboniferous sequences are thought to be controlled by glacio-eustasy (Heckel, 1986; Klein and Willard, 1989; Miller and Eriksson, in press), and reflect Milankovitch periodicities of 100-400 k.y. The four sequences making up the Bluefield Formation record transgressions and regressions correlatable through both marine and non-marine environments, supporting a glacioeustatic control over intrabasinal autocyclic events, or high frequency regional tectonic episodes.

The formation of $4^{\text {th }}$ order, regionally mappable sequences in the Appalachian Basin coincides with the onset of global cyclic deposition and the southern hemisphere glaciation (Veevers and Powell, 1987). The period from $335 \mathrm{Ma}$ to $268 \mathrm{Ma}$ was characterized by globally correlative transgressions and regressions inferred to be of eustatic origin. The interval of cyclic deposition corresponds with the start and end of glaciation on the Gondwanan supercontinent $( \pm 2-3 \mathrm{Ma})$ suggesting that many sequences 
deposited during the late Paleozoic were influenced, if not controlled by, glacio-eustatic fluctuations (Crowell, 1978; Veevers and Powell, 1987). Further biostratigraphic constraints would help define the inferred link between Bluefield Formation sequence development and glacio-eustasy.

\section{$5^{\text {th }}$ Order Parasequences}

The four $4^{\text {th }}$ order sequences in the Bluefield Formation are composed of stacked upward shallowing $5^{\text {th }}$ order parasequences. Since erosion was minimal in the depocenter, it contains the most complete record of deposition. Here the regionally

mappable, $4^{\text {th }}$ order sequences are composed of up to 28 recognizable parasequences (Fig. 7). The flooding surfaces and facies shifts that separate parasequences record rises in relative sea-level. An average of 9 parasequences make up each siliciclasticdominated sequence (sequences 3 and 4); hence the duration of each parasequence was between 70 k.y. and 90 k.y. These estimates are subject to error because of poor biostratigraphic control, indirect correlation to geochronologic age constraints, and possible removal of section at the upper composite sequence boundary. Due to these uncertainties, it is likely that each parasequence represents between 40 to 50 k.y. Fewer parasequences are recognized within the lower Bluefield Formation (sequences 1 and 2); this is attributed to poor exposure, and lack of sensitivity of the open-marine record to small relative sea-level rises.

Controls on the development of stacked parasequences separated by flooding surfaces can be classified as autocyclic or allocyclic or a combination of both (Yang et al., 1998). Autocyclicity invokes mechanisms such as sediment compaction and delta 
lobe-switching related to channel avulsion. Allocyclic mechanisms include tectonic subsidence due to faulting, or cyclic eustatically controlled, high-frequency fluctuations in sea-level (Mitchum and Van Wagoner, 1991). Autocyclic mechanisms influenced the development of some parasequences, as evidenced by the occasional stacked, coastalplain paleosol horizons and the turbidity current-generated carbonate beds. However, autocyclic mechanisms are too localized to explain the repetitively stacked nature of shallow coastal plain to open marine parasequences throughout the Bluefield Formation. An autocyclic control on sequence development requires that sea levels remain static for long periods of time (Kozar et al., 1990). However, it is generally agreed that regional sea-levels have not remained static for any significant geologic time-span, and especially not during the waxing and waning of the Gondwana glaciation (Koerschner and Read, 1990).

Many workers have suggested episodic thrust-induced subsidence as the dominant control on deposition of Late Carboniferous strata in the Appalachian Basin (e.g. Tankard, 1986; Klein and Kupperman, 1992; Ettensohn, 1994). Deposition of the Bluefield Formation was concomitant with deformation associated with the Alleghenian orogeny. However, it is unlikely Alleghenian deformation could have caused the basinwide, jerky subsidence needed to form the meter-scale parasequences. In outcrop, no evidence of soft-sediment deformation features exists to support episodic tectonic disturbances. Additionally, periodic basin-wide faulting would create instantaneous accommodation, a situation which is not compatible with the slow rates of initial sealevel rise inferred for development of coals at some parasequence flooding surfaces. 
A eustatic control on Carboniferous, high-frequency cyclic sedimentation has been proposed by previous workers in the Appalachian Basin (e.g. Busch and Rollins, 1984; Al Tawil, 1998; Smith, 1996; Miller and Eriksson, in press). The basin-wide extent of parasequences, and the approximately similar number of parasequences within each sequence, favor high-frequency eustatic fluctuations in sea-level as the dominant control on parasequence development in the Bluefield Formation.

\section{TECTONO-STRATIGRAPHIC ZONES}

The stratal geometry of the Mauch Chunk Group including the Bluefield Formation reflects differential subsidence of the Appalachian Foreland Basin. The easterly-thickening of the sedimentary package is compatible with most active forelandbasin settings in which subsidence rates increase toward the orogenic belt, and vary temporally along strike (Posamentier and Allen, 1993). Within these basins, there exists a point where eustatic change equals subsidence. This point separates two tectonostratigraphic zones, zone A where the rate of subsidence always exceeds the rate of eustatic fall, and zone B where the rate of eustatic fall periodically exceeds the rate of subsidence (Posamentier and Allen, 1993; Schwanns, 1995). Zone A is typified by stratigraphic successions that reflect different rates of continuous relative sea-level rise. Eustatic lowering within zone B is commonly manifested by subaerially formed unconformities, and possibly incised valleys (Posamentier and Allen, 1993). Differing and complex effects on sequences, sequence boundaries and parasequences are caused by the interaction between eustasy and tectonic zonation. 
In basin-margin locations, the upper two siliciclastic sequences are defined by incised-valley sandstones and fewer parasequences than in the depocenter. These features are consistent with zone B of Posamentier and Allen (1993). In the basin depocenter, temporally equivalent sequence boundaries show no evidence for erosion and instead are represented by conformable parasequences (Fig. 28). This is consistent with the more rapidly subsiding zone A of Posamentier and Allen (1993). Parasequences that define sequence boundaries in the depocenter characteristically contain basal coals (Fig. 29).

The presence of basal coals within parasequences at depocenter sequence boundaries implies slow rates of relative sea-level rise during these periods. Viewed as simplified sinusoidal waves, the rate of $5^{\text {th }}$ order eustatic change varies with respect to position within a $4^{\text {th }}$ order sea-level cycle (Fig. 30). During $4^{\text {th }}$ order sea-level falls, $5^{\text {th }}$ order transgressions would have been relatively slow. These slow rates of transgression favored the development of parasequences containing thin coals in the depocenter (zone A of Posamentier and Allen, 1993). During $4^{\text {th }}$ order sea-level rise and stillstand, an accelerated $5^{\text {th }}$ order sea-level rise resulted in rapid salt-water inundation of well-drained coastal-plain facies.

The absence of unconformities bounding the two lower sequences, and the dominance of open-marine facies throughout basin-margin and depocenter locations within the Bluefield Formation, indicates that both zones A and B remained below sealevel. This implies that subsidence rates exceeded maximum rates of eustatic fall. Sequence boundaries within these laterally continuous packages are demarcated by regionally-distinctive hemipelagic shales. 


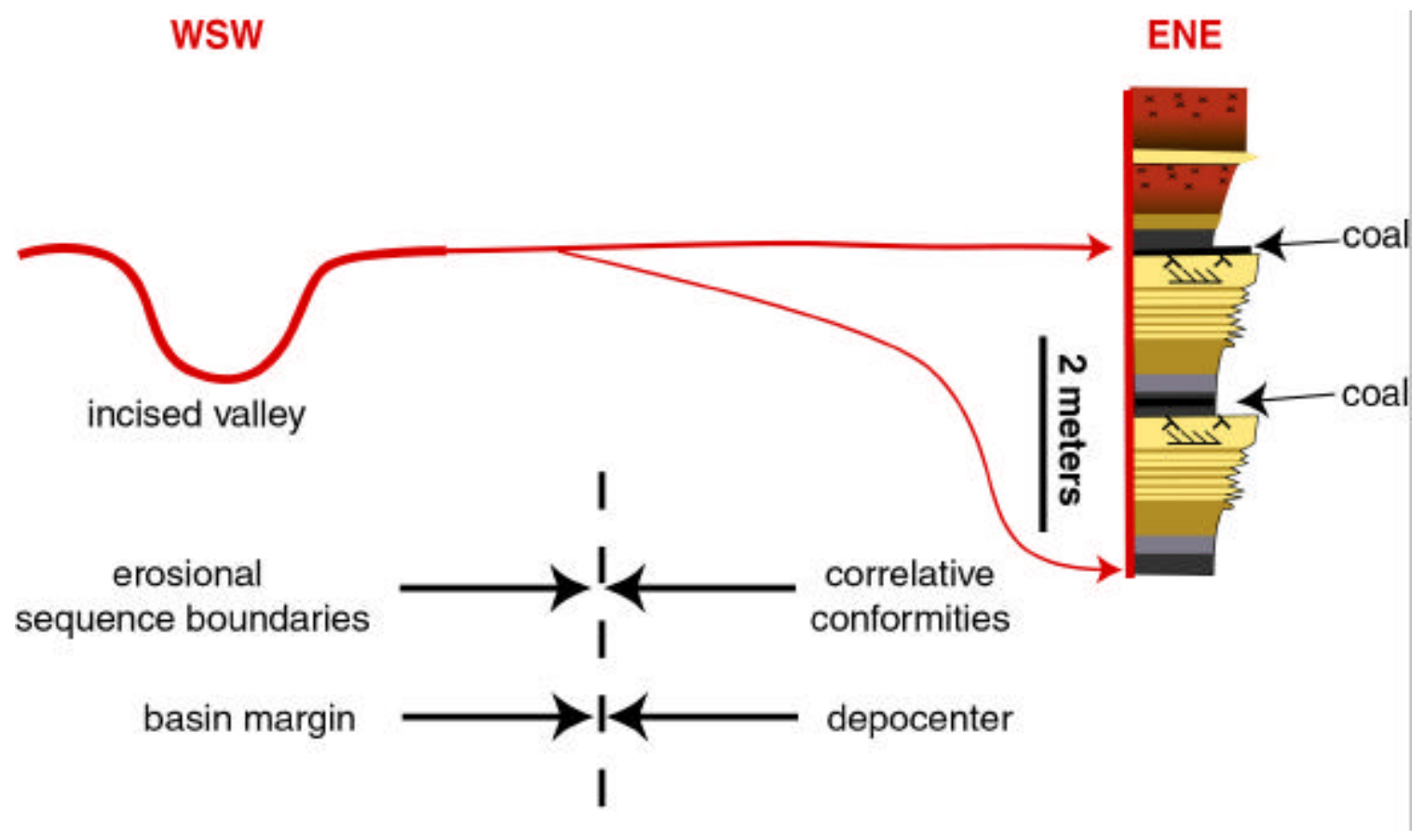

Figure 28: Schematic cross section illustrating the temporal equivalence of incised valleys along the basin margin and conformable sequence boundaries defined by coal-bearing parasequences in the depocenter. 


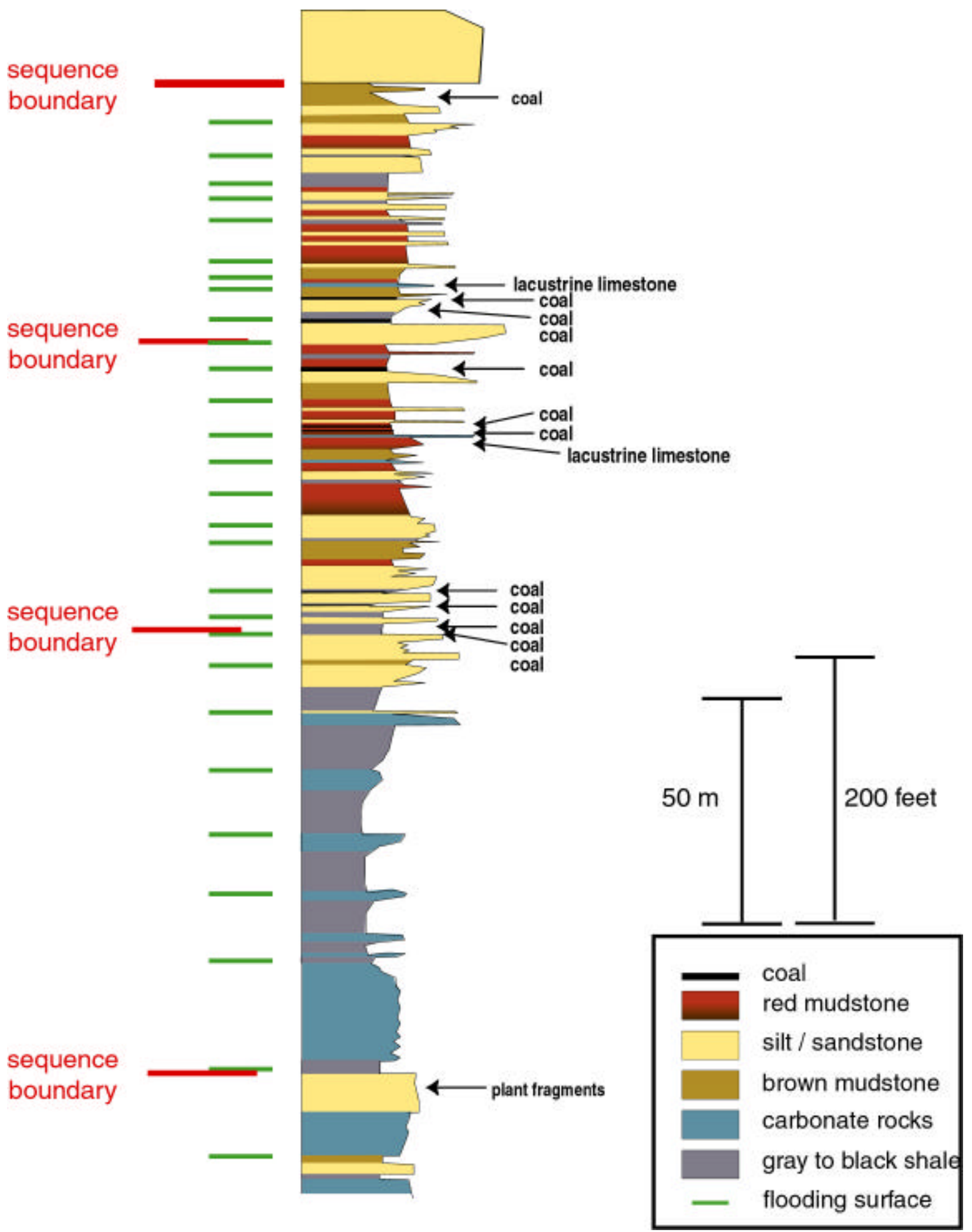

Figure 29: Simplified and annotated outcrop section from depocenter showing the location of coals and freshwater limestones with respect to regionally traceable sequence boundaries. 

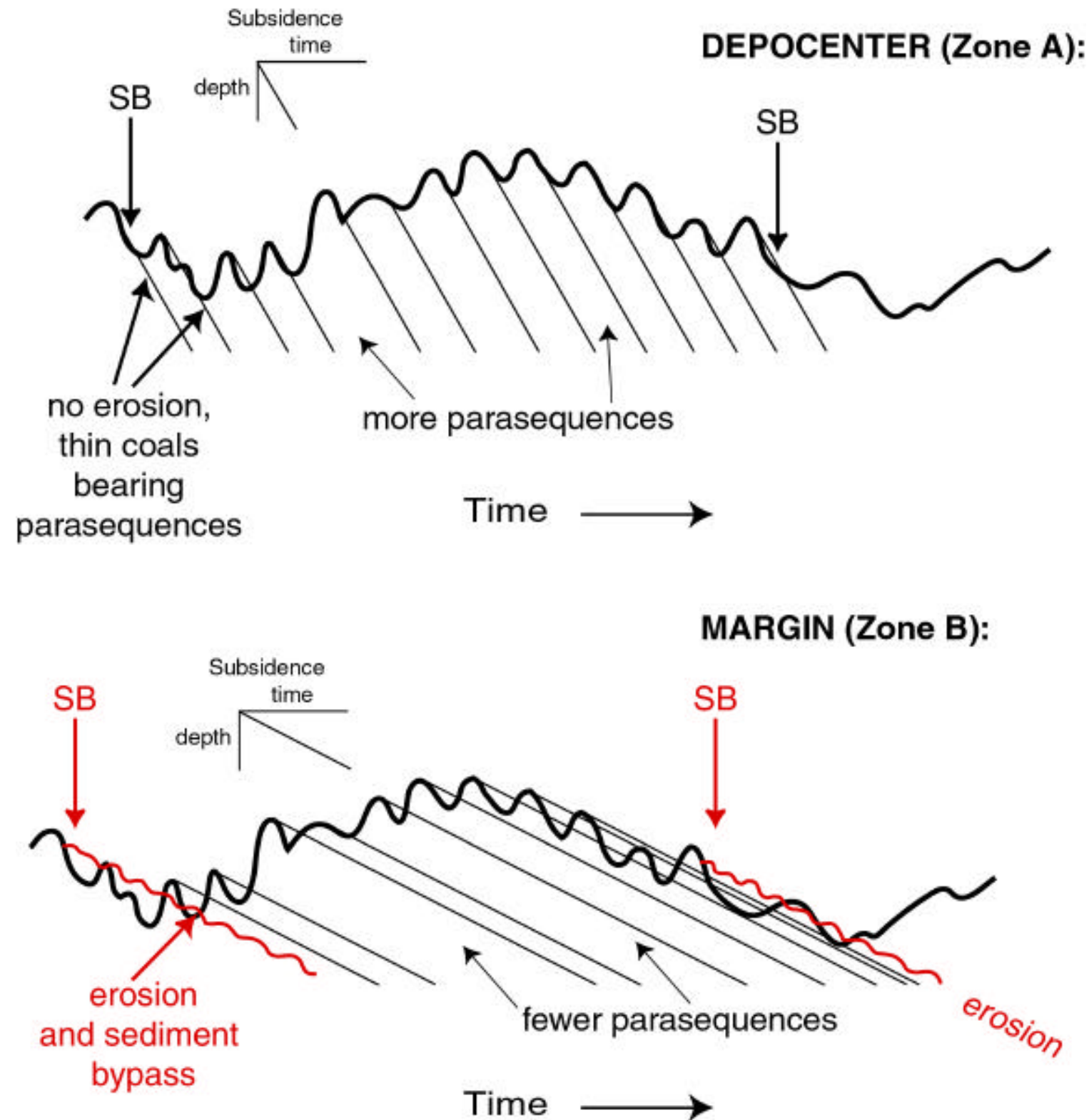

Figure 30: Schematic diagrams showing the interaction between $4^{\text {th }}$ and $5^{\text {th }}$ order eustatic fluctuations and differential subsidence rates related to thrust and sediment loading. In depocenter locations (tectono-stratigraphic zone A of Posamentier and Allen, 1993), high rates of subsidence allowed for the development of $5^{\text {th }}$ order parasequences during $4^{\text {th }}$ order lowering of sea-level. Basinmargin locations (tectono-stratigraphic zone B of Posamentier and Allen, 1993) experienced less accommodation, resulting in incision during $4^{\text {th }}$ order lowering of sea-level. Sequences along the basin margin record fewer parasequences. 


\section{CONCLUSIONS}

1) The Bluefield Formation encompasses approximately 3 million years of deposition in the Appalachian foreland basin. Within this time span, tectonic and eustatic mechanisms governed the stratal patterns observed both in outcrop and in regional subsurface cross-sections.

2) The Bluefield Formation represents a wedge-shaped, $3^{\text {rd }}$ order composite sequence. Long-term accommodation resulted from emplacement of thrust sheets to the southeast and produced the distinct tectono-stratigraphic zonation within the basin. A tectono-eustatic control on the development of the study interval is suggested due to equivalence of the Glen Dean unconformity bound composite sequence. A regional tectonic control inadequately explains the observation that $3^{\text {rd }}$ order sea-level curves from the mid-continent are recognizable worldwide (Ross and Ross, 1988).

3) The composite sequence is composed of four regionally mappable $4^{\text {th }}$ order sequences. Each sequence is bounded by erosional unconformities or distinct conformities marked by either pelagic shales or thin coal bearing parasequences. The upper two sequences are typified by heterogeneous, siliciclastic coastal plain sediments. These sequences are bounded by unconformities and incised valley sandstones in distal, basin-margin regions (or Zone B), and conformities characterized by the development of coal horizons in the proximal depocenter (or Zone A). The two lower, open- to shallowmarine-dominated sequences are bound by pelagic transgressive shales and contain fewer recognizable parasequences.

4) The $4^{\text {th }}$ order depositional sequences reflect glacio-eustatic changes associated with the waxing and waning of the Gondwanan glaciation. 
5) The four $4^{\text {th }}$ order sequences in the Bluefield Formation are composed of stacked, upward shallowing, meter-scale parasequences. Outcrops in the depocenter contain up to twenty-eight, stacked parasequences, each bounded by flooding surfaces. Development and stacking of parasequences is attributed to high-frequency (40-50 k.y.?) eustatic sea-level fluctuations.

5) The stratal expression of $4^{\text {th }}$ order sequence boundaries was controlled by differential subsidence in the basin. Erosion to produce incised valleys on the basin margins was synchronous with the development of coal-bearing conformable parasequences in the depocenter.

6) Development of coals within dominantly arid parasequences in zone A illustrates the effects of superimposed short-term, glacio-eustatically driven $4^{\text {th }}$ and $5^{\text {th }}$ order cyclicity on longer-term tectono-eustatic subsidence.

7) This study has shown the Bluefield Formation records a hierarchy of glacioeustatically driven sea-level cycles superimposed on longer-term differential subsidence associated with Alleghenian thrust loading. The Bluefield Formation records a transitional time interval during which both icehouse and greenhouse type eustatic changes controlled development of depositional sequences and parasequences. However, the expression of these sea-level changes in the stratigraphic record was governed by varied rates of subsidence across the basin. 


\section{REFERENCES}

Al-Tawil, A., 1998, High resolution sequence stratigraphy of Late Mississippian carbonates in the Appalachian Basin [unpublished Ph.D. Dissertation]: Blacksburg, Virginia, Virginia Tech, 109 p.

Archer, A. W., Kuecher, G.J., and Kvale, E.P., 1995, The role of tidal velocity asymmetries in the deposition of silty tidal rhythmites (Carboniferous, eastern interior coal basin, U.S.A.): Journal of Sedimentary Research, v. A 65, no. 2, p. 408-416.

Archer, A. W., Kvale, E. P., and Johnson, H. R., 1991, Analysis of modern equatorial tidal periodicities as a test of information encoded in ancient tidal rhythmites. In Smith, D.G., Reinson, G.E., Zaitlin, B.A., and Rahmani,R.A., eds., Clastic Tidal Sedimentology. Canadian Society of Petroleum Geologists. Memoir 16, p. 189196.

Arkle, T., Beissel, D.R., Larese, R.E., Nuhfer, E.S., Patchen, D.G., Smosna, R.A., Gillespie, W.H., Lund, R., Norton, C.W., and Pfefferkorn, H.W., 1979, The Mississippian and Pennsylvanian (Carboniferous) Systems in the United States West Virginia and Maryland: U.S. Geological Survey, Professional Paper 1110$\mathrm{D}, 35 \mathrm{p}$.

Beek, J.L. and Koster, E.A., 1972, Fluvial and estuarine sediments exposed along the Oude Maas (The Netherlands): Sedimentology, v. 19, p. 237-256.

Blodgett, R. H., 1988, Calcareous paleosols in the Triassic Dolores Formation, Soutwestern Colorado, in Reinhardt, J., and Sigleo, W.R., eds., Paleosols and Weathering Through Geologic Time: Principles and Applications: Geological Society of America, Special Paper 216, p. 103-122.

Boardman, E.L., 1989, Coal Measures, Namurian and Westphalian, Blackband Iron Formations: fossil bog iron ores: Sedimentology, v. 36, p. 621-633.

Bohacs, K., and Suter, J., 1997, Sequence stratigraphic distribution of coaly rocks: Fundamental controls and paralic examples: American Association of Petroleum Geologists, Bulletin, v. 81, p.1612-1639.

Bridges, P.H., 1972, The significance of toolmarks on a Silurian erosional furrow: Geological Magazine, v. 109, p. 405-410.

Brown, T.M. and Kraus, M.J., 1981, Lower Eocene alluvial paleosols (Willwood Formation, northwest Wyoming, U.S.A), and their significance for paleoecology, paleoclimatology, and basin analysis: Palaeogeography, Palaeoclimatology, and Palaeoecology, v. 34, p. 1-30. 
Buising, A., Dewit, A., Newton, S., Simmons, A., Smyth, D., Taylor, L., Boeche, R., Cheel, D., Eckman, N., Larson, K., Murphy, L., Sager, T., and Smith, C., 1996, Storm- and tide- controlled carbonate-silici-clastic mixing on a laterally variable open shelf, Poleta Formation, White Mountains, CA: American Association of Petroleum Geologists, Bulletin, v. 81, p. 681.

Busch, R. M. and Rollins, H. B., 1984, Correlation of Carboniferous strata using a hierarchy of transgressive-regressive units: Geology, v. 12, p. 471-474.

Butts, C., 1933, Geologic map of the Appalachian Valley of Virginia with explanatory text: Virginia Geological Survey, Bulletin, 56 p.

Butts, C., 1940, Geology of the Appalachian Valley in Virginia, Part 1: Virginia Geological Survey, Bulletin, v. 52, 568 p.

Campbell, M.R., 1896, Geological Atlas of the United States, Pocahontas Folio (No. 26). U.S. Geological Survey.

Cecil, C.B., Dulong, F.T., Edgar, N.T., and Ahlbrandt, T.S., 1994, Carboniferous paleoclimates sedimentation and stratigraphy, in Cecil, C.B., and Edgar, N.T., eds., Predictive Stratigraphic Analysis-Concepts and Application: U.S. Geological Survey, Bulletin 2110, p. 27-28.

Christopher, C.C., 1992, Marine paleocommunities and paleoenvironments of the Upper Mississippian Bluefield Formation in southern West Virginia [unpublished Ph.D. dissertation], Morgantown, West Virginia, West Virginia University, 468 p.

Cleal, C.J. and Thomas, L.P., 1996, British Upper Carboniferous Stratigraphy: Chapman and Hall, London, 339 p.

Cloetingh, S., 1988, Intraplate stresses: A tectonic cause for third-order cycles in apparent sea-level?, in C.W. Wilgus, H.W. Posamentier, C.A. Ross, and C.G.St.C. Kendall, eds., Sea-Level Changes-An Integrated Approach: SEPM, Special Publication 42, p. 19-29.

Collinson, J.D., 1996, Alluvial sediments, in Reading, H.G., ed., Sedimentary Environments: Processes, Facies and Stratigraphy ( ${ }^{\text {rd }}$ Edition): Blackwell Science, Oxford, p. 37-83.

Collinson, J.D., and Thompson, D.B., 1989, Sedimentary Structures: Chapman \& Hall, London, 207 p.

Cooper, B.N., 1944, Geology and mineral resources of the Burkes Garden quadrangle, Virginia: Virginia Geological Survey, Bulletin, v. 60, 299 p. 
Cooper, B.N., 1961, Grand Appalachian field excursion, Field Trip 1 of Geological Society of America Annual Meeting, Cincinnati, Ohio: Virginia Polytechnic Institute, Engineering Extension Series, Geological Guidebook, no. 1, 187 p.

Cotter, E., and Driese, S.G., 1998, Incised valley fills and other evidence of sea-level fluctuations affecting deposition of the Catskill Formation (Upper Devonian), Appalachian Foreland Basin, Pennsylvania: Journal of Sedimentary Research, v. 68 , p. $347-361$.

Crowell, J.C., 1978, Gondwanan glaciation, cyclothems, continental positioning, and climate change: American Journal of Science, v. 278, p. 1345-1372.

Dalrymple, R.W., Makino, Y., and Zaitlin, B. A., 1991, Temporal and spatial patterns of rhythmite deposition on mud flats in the macrotidal Cobequid Bay-Salmon River estuary, Bay of Fundy, Canada, in Smith, D.G., Reinson, G.E., Zaitlin, B.A., and Rahmani, R.A., eds., Clastic Tidal Sedimentology: Canadian Society of Petroleum Geologists. Memoir 16, p. 137-160.

De Boer, P.L., Oost, A.P., and Visser, M.J., 1989, The diurnal inequality of the tide as a parameter for recognizing tidal influences: Journal of Sedimentary Research, v. 59, p. 912-921.

DeWitt, Jr., and McGrew, L.W., 1979, Appalachian Basin Region. in L.C. Craig, C.W., and Connor, eds., Paleotectonic investigation of the Mississippian System in the United States Part I: Introduction and regional analysis of the Mississippian System: United States Geological Survey, Professional Paper 1010, p. C12-C48.

Dickinson, W.R., Soreghan, G.S., and Giles, K.A., 1994, Glacio-eustatic origin of PermoCarboniferous stratigraphic cycles: Evidence from the southern Cordilleran foreland region, in Dennison, J.M., and Ettensohn, F., eds., Tectonic and Eustatic controls on sedimentary cycles: SEPM concepts in Sedimentology and Paleontology, v. 4, p. 25-34.

DiVenere, V.J., and Opdyke, N.D., 1991, Magnetic polarity stratigraphy in the uppermost Mississippian Mauch Chunk Formation, Pottsville, Pennsylvania: Geology, v. 19, p. 127-130.

Donaldson, A.C. and Shumaker, R., 1981, Late Paleozoic molasse of the Central Appalachians: Geological Associations of Canada, Special Paper 23, p. 99-124.

Duke, W.L., 1990, Geostrophic circulation or shallow marine turbidity currents? The dilemma of paleoflow patterns in storm-influenced prograding shoreline systems: Journal of Sedimentary Petrology, v. 60, p. 870-883.

Duke, W.L., and Prave, A.R., 1991, Storm- and tide- influenced prograding shoreline sequences in the Middle Devonian Mahantango Formation, Pennsylvania, in 
Smith, D.G., Reinson, G.E., Zaitlin, B.A. and Rahmani, R.A., eds., Clastic Tidal Sedimentology: Canadian Society of Petroleum Geologists, Memoir 16, p. 349-370.

Englund, K.J., Arndt, H.H., and Henry, T.W., 1979, Proposed Pennsylvanian System stratotype, Virginia and West Virginia: American Geological Institute, Selected Guidebook Series 1, 138 p.

Englund, K.J., and Thomas, R.E., 1990, Late Paleozoic depositional trends in the Central Appalachian Basin: U.S. Geological Survey, Bulletin 1839-F, 19 p.

Ettensohn, F.R., 1994, Tectonic control on formation and cyclicity of major Appalachian unconformities and associated stratigraphic sequences, in Dennison, J.M., and Ettensohn, F., eds., Tectonic and Eustatic controls on sedimentary cycles: SEPM concepts in Sedimentology and Paleontology, v. 4, p. 217-242.

Filer, J. K., 1994, High frequency eustatic and siliciclastic sedimentation cycles in a foreland basin, Upper Devonian, Appalachian basin, in Dennison, J.M., and Ettensohn, eds., Tectonic and Eustatic controls on sedimentary cycles: SEPM concepts in sedimentology and paleontology, v. 4, p. 133-146.

Frazier, D.E., 1967, Recent deltaic deposits of the Mississippi River: their development and chronology: Transactions of the Gulf Coast Association of Geological Societies, v. 17, p. 287-315.

Freeze, R.A. and Cherry J.A., 1979, Groundwater: Prentice-Hall, Englewood Cliffs, N.J. Prentice-Hall, 600 p.

Frenzel, B., 1983, Mires: repositories of climatic information or self-perpetuating ecosystems, in Gore, A.J.P., ed., Mires: Swamp, Bog, Fen, and Moor: General Studies, Ecosystems of the World, v. 4A: Elsevier, Amsterdam, p. 35-65.

Gardner, T. W., Williams, E.G., Holbrook, P.W., 1988, Pedogenesis of some Pennsylvanian underclays; ground-water, topographic, and tectonic controls, in J. Reinhardt, W.R. and Sigleo eds., Paleosols and weathering through geologic time: Principles and applications: Geological Society of America, Special Paper 216, p. 81-101.

Harrison, C.G.A., 1990, Long-term eustasy and epirogeny in continents, in Revelle, R., ed., Sea-level Change: National Research Council, Studies in Geophysics, Washington, D.C., National Academy Press, p. 141-158.

Heckel, P.H., 1986, Sea-level curve for Pennsylvanian eustatic marine transgressiveregressive depositional cycles along Midcontinent outcrop belt, North America: Geology, v. 14, p. 330-334. 
Henika, W.S., 1994, Internal structure of the coal-bearing portion of the Cumberland overthrust block in southwestern Virginia and adjoining areas, in Geology and Mineral Resources of the Southwest Virginia Coalfield: Virginia Division of Mineral Resources, Publication 131, p. 100-120

Humphreville, R.G., 1981, Stratigraphy and Paleoecology of the Upper Mississippian Bluefield Formation [unpublished M.S. Thesis]: Blacksburg, Virginia, Virginia Tech , $366 \mathrm{p}$.

Ingram, H.A.P., 1983, Hydrology, in Gore, A.J.P., ed., Mires: Swamp, Bog, Fen, and Moor: General Studies, Ecosystems of the World, v. 4A: Elsevier, Amsterdam, p. 67-150.

Jones, P.J., 1996, Carboniferous (Chart 5), in Young, G.C. and Laurie, J.R., eds. An Australian Phanerozoic Timescale: Oxford University Press, Melbourne, p. 110126.

Kirkland, M.J.,1985, Petrology and diagenesis of sandstones of the Bluefield Formation (Upper Mississippian), Southeast West Virginia [unpublished M.S. thesis]: Morgantown, West Virginia, West Virginia University, 120 p.

Klein, G., and Kupperman, J. B., 1992, Pennsylvanian cyclothems: methods of distinguishing tectonically induced changes in sea level from climatically induced changes: Geological Society of America, Bulletin, v. 104, p. 166-175.

Klein, G., and Willard, D.A., 1989, Origin of the Pennsylvanian coal-bearing cyclothems of North America: Geology, v. 17, p 152-155.

Koerschner, W.F. III, and Read, J.F., 1990, Field and modelling studies of Cambrian carbonate cycles, Virginia Appalachians-Reply: Journal of Sedimentary Petrology, v. 60, p. 795-796.

Kopaska-Merkel, D.C., Haywikk, D., and Robinson, J., 1998, A baffling Chesterian mud mound in North Alabama (abstract): Geological Society of America, Abstracts with Programs, v. 30, no. 7, p. 315.

Kozar, M.G., and Weber, L. J., and Walker, K. R., 1990, Field and modelling studies of Cambrian carbonate cycles, Virginia Appalachians-Discussion: Journal of Sedimentary Petrology, v. 60, p. 790-794.

Maguregui, J., and Tyler, N., 1991, Evolution of Middle Eocene tide-dominated deltaic sandstones, Lagunillas Field, Maracaibo Basin, Western Venezuela, in Miall, A.D., and Tyler, N, eds., The three-dimensional facies architecture of terrigenous clastic sediments, and its implications for hydrocarbon discovery and recovery: SEPM Concepts in Sedimentology and Paleontology, v. 3, Tulsa, p. 233-244. 
McDowell, R. C., 1982, The Hurricane Ridge, Glen Lyn, and Caldwell synclines of southeastern West Virginia and southwestern Virginia; a reinterpretation: Southeastern Geology, v. 23, p. 83-88.

Melhop, A. M., Dennison, J. M., and Stewart, K. G., 1996, Extensional structures along the Allegheny Front in Virginia and West Virginia near the Giles county seismic zone (abstract): Geological Society of America, Abstracts with Programs, v. 28, no 7, p. 239.

Miall, A. D., 1984, Deltas, in Walker R.G., ed., Facies Models, second edition: Geological Association of Canada, p. 105-118.

Miller, D.J., 1998, Depositional environments and sequence stratigraphy of Upper Mississippian strata in the Central Appalachian Basin [unpublished Ph.D. Dissertation]: Blacksburg, Virginia, Virginia Tech, 87 p.

Miller, D.J. , and Eriksson, K. A., 1997, Late Mississippian prodeltaic rhythmites in the Appalachian Basin; a hierarchical record of tidal and climatic periodicities: Journal of Sedimentary Research, Section B, Stratigraphy and Global Studies, v. 67, p. 653-660.

Miller, D.J. and Eriksson, K. A., in press, Sequence Stratigraphy of Upper Mississippian strata in the central Appalachians: a record of glacioeustasy and tectonoeustasy in a foreland basin setting: American Association of Petroleum Geologists, Bulletin, v. 84 (2).

Miller, M. S., 1973, Stratigraphy and depositional systems of Carboniferous rocks in southwest Virginia [unpublished M.S. thesis]: Blacksburg, Virginia, Virginia Tech, $181 \mathrm{p}$.

Mitchum, R.M., and Van Wagoner, J.C., 1991, High-frequency sequences and their stacking patterns: sequence-stratigraphic evidence of high-frequency eustatic cycles: Sedimentary Geology, v. 70, p 131-160.

Molina, J.M., Ruiz-Ortiz, P.A., and Vera, J.A., 1997, Calcareous tempestites in pelagic facies (Jurassic, Betic Cordilleras, Southern Spain): Sedimentary Geology, v. 109, p. 95-109.

Montanez, I.P., and Osleger, D.A., 1993, Parasequence stacking patterns, third-order accommodation events, and sequence stratigraphy of Middle to Upper Cambrian platform carbonates, Bonanza King Formation, southern Great Basin, in R. G. Loucks and J.F. Sarg, eds., Carbonate sequence stratigraphy; recent developments and applications: American Association of Petroleum Geologists Memoir 57, p. 305-326.

Moore, P.D., 1989, The ecology of the peat-forming processes: a review: International Journal of Coal Sciences, v. 12, p. 89-103. 
Mora, C.I., Dreise, S.G., and Seager, P.G., 1991, Carbon dioxide in the Paleozoic atmosphere: evidence from carbon-isotope compositions of pedogenic carbonate: Geology, v. 19, p. 1017-1020.

Nolde, J.E., 1994, Devonian to Pennsylvanian stratigraphy and coal beds of the Appalachian plateaus province, in Geology and Mineral resources of the southwest Virginia coalfield: Virginia Division of Mineral Resources, Publication 131, 85 p.

Olsen, P. E., 1990, Tectonic, climatic and biotic modulation of lacustrine ecosystems; examples from Newark Supergroup of eastern North America, in Katz, B.J., ed., Lacustrine basin exploration; case studies and modern analogs: American Association of Petroleum Geologists, Memoir 50, p. 209-224.

Opdyke, N.D., and DiVenere, V.J., 1994, Paleomagnetism and Carboniferous climate, in Cecil, C.B., and Edgar, N.T.,eds., 1994, Predictive Stratigraphic AnalysisConcepts and Application: U.S. Geological Survey, Bulletin 2110, p. 8-28.

Pflacker, G., 1965, Tectonic deformation associated with the 1964 Alaska earthquake: Science, v. 148, p. 1675-1687.

Pope, M., Read, J.F., 1998, Ordovician metre-scale cycles; implications for climate and eustatic fluctuations in the Central Appalachians during a global greenhouse, nonglacial to glacial transition: Palaeogeography, Paleaeoclimatology, Palaeoecology, v. 138, p. 27-42.

Posamentier, H.W., and Allen, G.P., 1993, Siliciclastic sequence stratigraphic patterns in foreland ramp-type basins: Geology, v. 21, p. 455-458.

Reading, H.G., 1986, Facies, in Reading, H.G., ed., Sedimentary Environments and Facies, Blackwell Scientific, Oxford, p. 4-20.

Reading, H.G. and Collinson C., 1996, Clastic Coasts. in Reading, H.G, ed., Sedimentary Environments: Processes, Facies and Stratigraphy, (3rd edition): Blackwell Science, Oxford, p. 154-232.

Reger, D.B., 1926, Mercer, Monroe and Summers Counties, West Virginia Geological Survey, p. 963.

Retallack, G.J., 1988, Field recognition of paleosols, in Reinhardt, J. and Sigleo, W.R., eds., Paleosols and Weathering Through Geologic Time: Principles and Applications: Geological Society of America, Special Paper 216, p. 1-20.

Roberts, J., Claoe-Long, J., Jones, P.J., and Forster, C. B., 1995, SHRIMP zircon age control of Gondwanan sequences in Late Carboniferous and Early Permian 
Australia, in Dunay, R.E. and Hailwood, E.A., eds., Non-biostratigraphical Methods of Dating and Correlation: Geological Society London, Special Publications, no.89, p. 145-174.

Rodgers, J., 1964, Basement and no-basement hypotheses in the Jura and the Appalachian Valley and Ridge, in Lowry, W.D., Tectonics of the southern Appalachians, Memoir - Department of Geological Sciences, Virginia Polytechnic Institute and State University, p. 71-80.

Ross, C.A., and Ross, J.R.P., 1988, Late Paleozoic transgressive-regressive deposition, in Wilgus, C.W., Posamentier, H.W., Ross, C.A., and Kendall, C.G., eds., Sea-Level Changes-An Integrated Approach: SEPM Special Publication 42, p. 228-247.

Schwans, P., 1995, Controls on sequence stacking and fluvial to shallow-marine architecture in a foreland basin, in Van Wagoner, J.C., and Bertram, G.T., eds., Sequence Stratigraphy of Foreland Basins, Outcrop and Subsurface Examples from the Cretaceous of North America: American Association of Petroleum Geologists, Memoir 64, p. 55-102.

Scotese, C.R., 1995, Phanerozoic Plate Tectonic Reconstructions, PALEOMAP Progress Report \# 36, Dept. of Geology, University of Texas at Arlington

Scotese, C.R., and Barrett, S.F., 1990, Gondwana's movement over the South Pole during the Paleozoic: evidence from lithological indicators of climate, in McKerrow, W.S. and Scotese, C.R., eds., Paleozoic Paleogeography and Biogeography, Geological Society Memoir, No. 12, p. 75-85.

Scotese, C.R., Bambach, R.K., Barton, C., Van der Voo, R. and Zeigler, A.M., 1979. Paleozoic base maps: Journal of Geology, v. 87, p. 217-277.

Simonsen, A.H., 1981, Paleoecology of Fenestrate Bryozoans in the Wymps Gap Limestone of southwestern Pennsylvania: Pennsylvania Geology, v. 12, p.11-15.

Smith, L.B., Jr., 1996, High-resolution sequence stratigraphy of Late Mississippian (Chesterian) mixed carbonates and siliciclastics, Illinois Basin [unpublished Ph.D Dissertation]: Blacksburg, Virginia, Virginia Tech, 146 pp.

Sundberg, F. A, Bennington, B.J., Wizevich, M.C., and Bambach, R.K., 1990, Upper Carboniferous (Namurian) amphibian trackways from the Bluefield Formation, West Virginia, USA: Ichnos, v.1, p. 111-124.

Swires, C. J, 1972, Source area of Mauch Chunk sediments in the Hurricane Ridge syncline in southeastern West Virginia [upublished M.S. thesis]: Akron, Ohio, University of Akron, $40 \mathrm{p}$.

Tankard, A.J., 1986, Depositional response to foreland deformation in the Carboniferous 
of eastern Kentucky: American Association of Petroleum Geologists, Bulletin, v.70, p. 853-868.

Thomas, W.A., 1966, Late Mississippian folding of a syncline in the western Appalachians, West Virginia and Virginia: Geological Society of America, Bulletin, v. 77, p. 473-494.

Tucker, M.E., 1982, The field description of sedimentary rocks, Tucker, Open University Press, New York,112 p.

Vail, P.R., Audemard, F., Bowman, S.A., Eisner, P.N. and Perez-Cruz, G., 1991, The stratigraphic signatures of tectonics, eustasy and sedimentation: an overview, in Seilacher, A., and Eisner, G., eds., Cycles and Events in Stratigraphy, II: Springer-Verlag, Tubingen, p. 617-659.

Vail, P.R., Mitchum, R.M. and Thompson, S. III, 1977, Seismic stratigraphy and global changes of sea level, Part 3: relative changes of sea level from coastal onlap. in C.W. Payton ed., Seismic Stratigraphic Applications to Hydrocarbon Exploration: American Association of Petroleum Geologists, Memoir 26, p. 6397.

Van Wagoner, J.C., Mitchum, R.M., Campion, K.M., and Rahmanian, V.D., 1990, Siliciclastic Sequence Stratigraphy in Well Logs, Cores, and Outcrops: Concepts for High-Resolution Correlation of Time and Facies: American Association of Petroleum Geologists, Methods in Exploration Series, no. 7, 55 p.

Van Wagoner J.C., 1995, Overview of sequence stratigraphy of foreland basin deposits: terminology, summary of papers, and glossary of sequence stratigraphy, in Van Wagoner, J.C., and Bertram, G.T., eds., Sequence Stratigraphy of Foreland Basin Deposits: American Association of Petroleum Geologists, Memoir 64, p. 1-13.

Veevers, J.J., and Powell, M., 1987, Late Paleozoic glacial episodes in Gondwanaland reflected in transgressive-regressive depositional sequences in Euramerica: Geological Society of America, Bulletin, v. 98, p. 475-487.

Vera, J.A., and Molina, J.M., 1998, Shallowing-upward cycles in pelagic troughs (upper Jurassic Subbetic, Southern Spain): Sedimentary Geology, v. 119, p. 103-121.

Walker, R.G., 1984, Geological evidence for storm transportation and deposition on ancient shelves, in Tillman, R.W., Swift, D.J.P., and Walker, R.G., eds., Shelf Sands and Sandstone Reservoirs: SEPM Short Course, p. 1-58.

Whisonant R. C., and Scolaro, R. J., 1980. Tide dominated coastal environments in the Mississippian Bluefield Formation of Eastern West Virginia, in Tanner, W.F., ed., Shorelines, Past and Present: Proceedings of the Fifth Symposium on 
Coastal Sedimentology; Geology Department, Florida State University.

v. 3 , p. 593-638.

Yang, W., Kominz, M.A., and Major, R.P. 1998, Distinguishing the roles of autogenic versus allogenic processes in cyclic sedimentation, Cisco Group (Virgilian and Wolfcampian), north-central Texas: Geological Society of America, Bulletin, v. 110, p. 1333-1353.

Zaitlin, B.A., Dalrymple, R.W., and Boyd R., 1994, Incised Valley Systems: Origin and Sedimentary Sequences: Special Publication of the Society of Sedimentary Geologists, Tulsa, Oklahoma, v. 51, 391 p. 
VITA

\section{JOEL P MAYNARD}

\section{EDUCATION}

M.S. Geology, December 1999

Virginia Tech, Blacksburg, VA

B.S. Geology, Spring 1996

Virginia Tech, Blacksburg, VA

\section{RELATED EXPERIENCE}

\section{Graduate Teaching Assistant}

Virginia Tech, Blacksburg, VA

Research Assistant

Virginia Tech, Blacksburg, VA

Undergraduate Research Project

Virginia Tech, Blacksburg, VA

Mining Night Shift

Luckstone Quarries, Centerville, VA

Summer Employee

Central Intelligence Agency, Langley, VA

$1997-1999$

Fall/Spring 1997

Spring 1996

1994

1993

\section{AWARDS AND CERTIFICATIONS:}

-Byron Nelson Cooper Memorial Fellowship (1999 + 1998)

-Sigma Xi - Grant in Aid of Research Award (1998)

-Emergency Medical Technician (1997)

-Undergraduate Dean's List (1994 - 1996)

-Terry Hamilton Scholarship for Drafting/Engineering (1992)

$\cdot 2^{\text {nd }}$ and $3^{\text {rd }}$ place awards in regional competitions for Computer Aided Isometric and Mechanical Drafting respectively

\section{PUBLICATIONS:}

Maynard, Joel P., Eriksson, K.A., and Law, R.D., 1999 Eustatic and tectonic controls on Late Mississippian sedimentation in the Appalachian basin: An outcrop and subsurface analysis of the Bluefield Formation: Geological Society of America Abstracts with Programs, v. 31, no. 7, p. 424

Maynard, Joel P., 1999, The Mississippian Bluefield Formation in the central Appalachian basin: A record of high frequency cyclic sedimentation. The fourth annual Virginia Tech Geological sciences student research symposium, book of abstracts.

Maynard, Joel P., 1998, Stratigraphic and structural analysis of the 
Mississippian Bluefield Formation of Virginia and West Virginia:

Relationships between Sedimentation and Pre-Alleghenian faulting. The third annual Virginia Tech Geological sciences student research symposium, book of abstracts. 


\section{APPENDIX A: MEASURED SECTIONS}

Jenkins, Kentucky
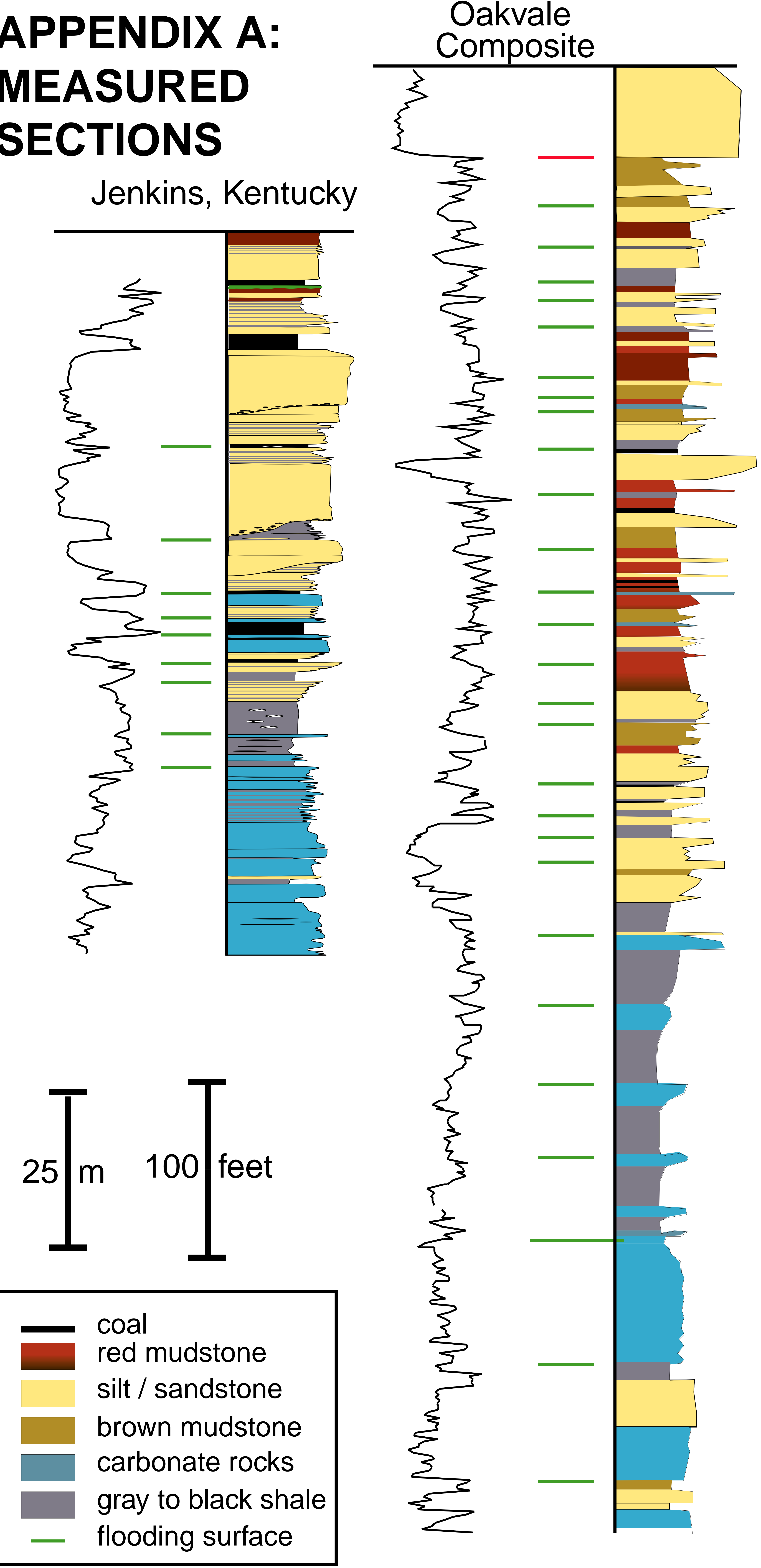


\section{APPENDIX A: WELL LOG CROSS SECTIONS}

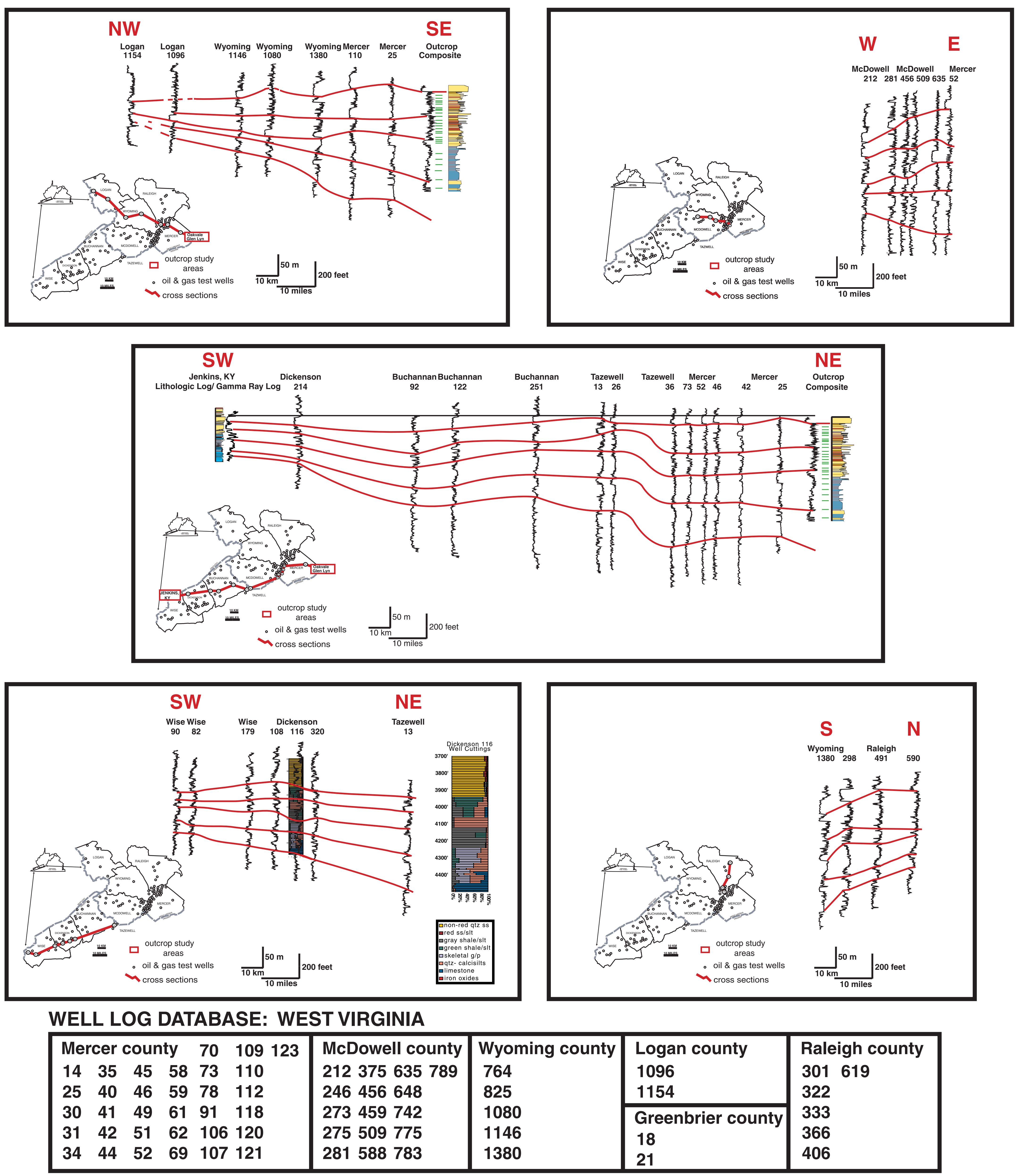

WELL LOG DATABASE: VIRGINIA

\begin{tabular}{|c|c|c|c|}
\hline Buchannan county & Dickenson county & Wise county & Tazewell county \\
\hline 87122166251 & $\begin{array}{llll}60 & 114 & 204 & 376\end{array}$ & 82192 & 836 \\
\hline 92129190 & $\begin{array}{llll}81 & 116 & 214 & 408\end{array}$ & 90221 & 13 \\
\hline 108144183 & $\begin{array}{llll}91 & 128 & 261 & 450\end{array}$ & 99276 & 17 \\
\hline 118161190 & 100180310 & 169 & 26 \\
\hline 120164199 & 108182320 & 179 & 27 \\
\hline
\end{tabular}




\section{APPENDIX C: ISOPACH MAPS}
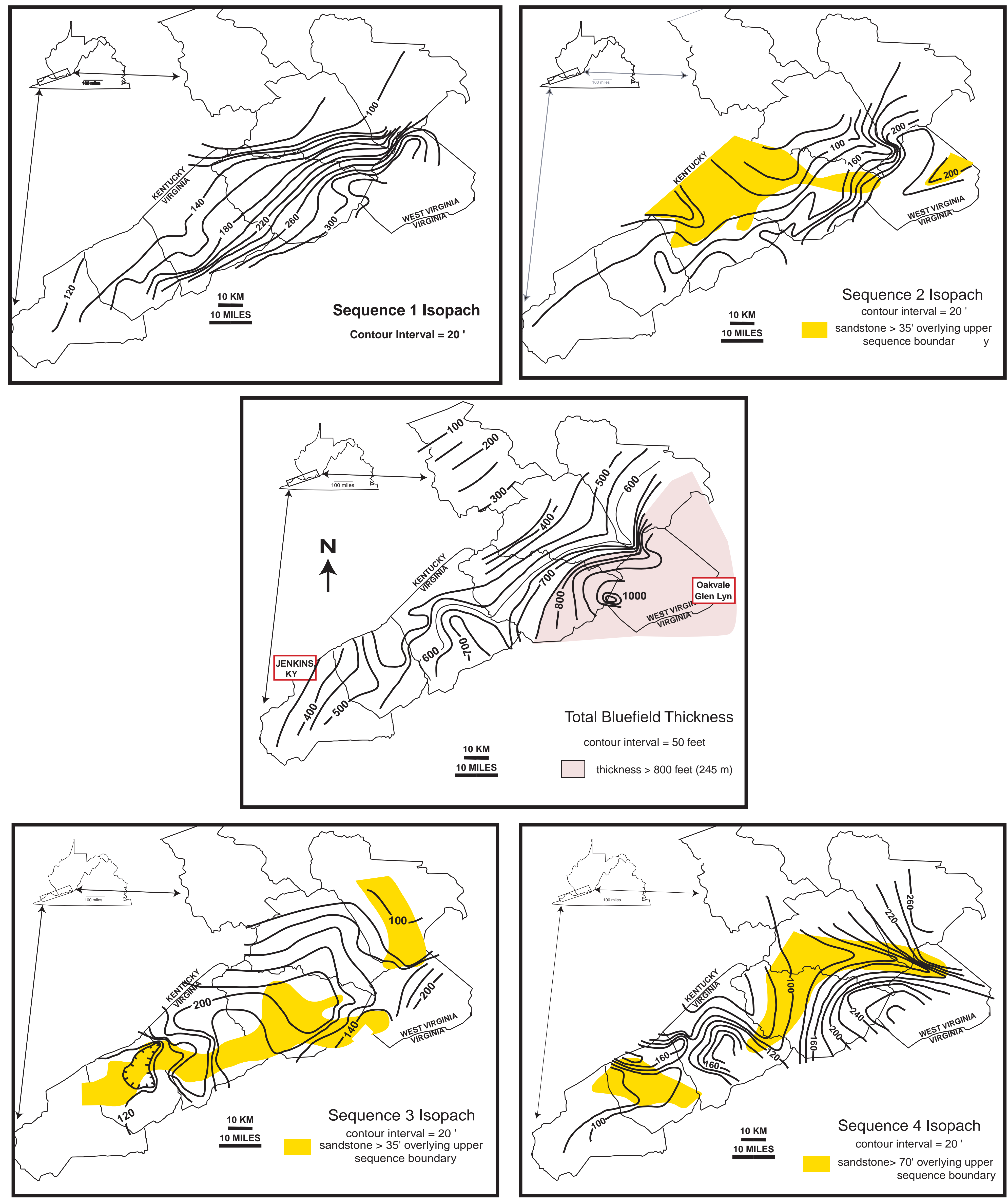


\section{APPENDIX D: ORIENTED STRUCTURAL PANEL DIAGRAMS}

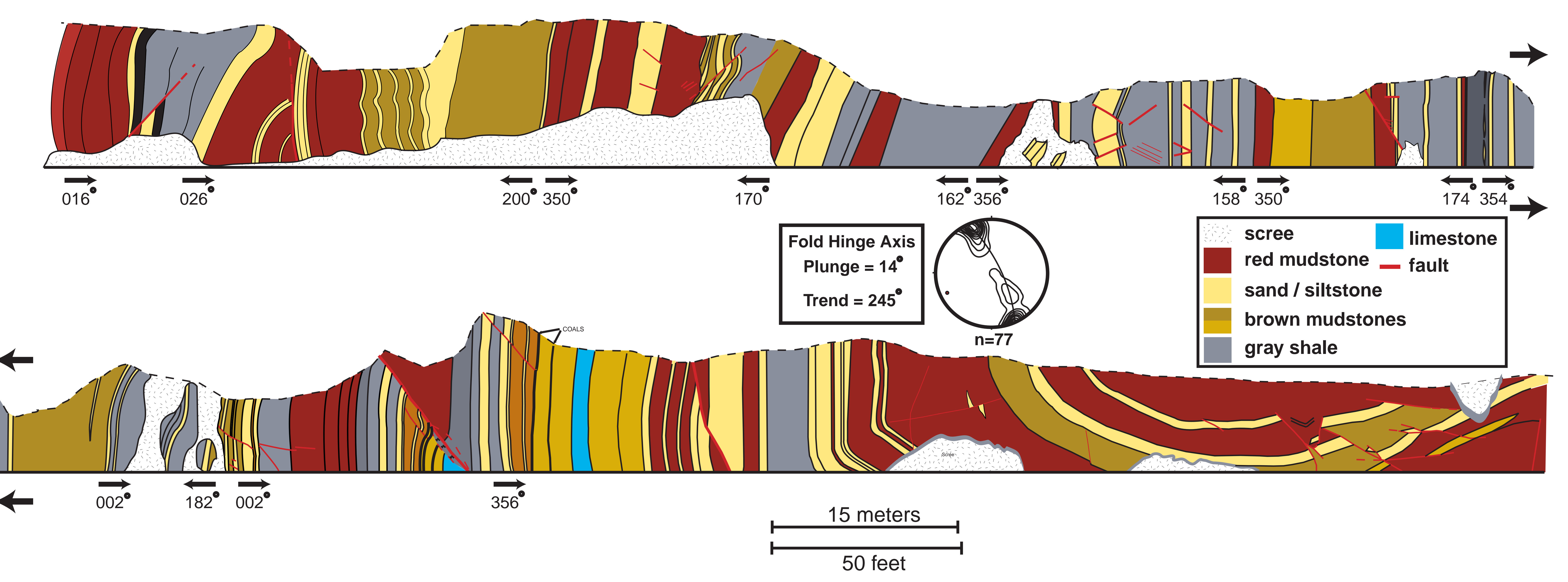




\section{APPENDIX E}

Data from the Glen Lyn outcrop location was corrected for structural deformation associated with the Glen Lyn syncline. Detailed structural analysis (see appendix B for structural information) of the Glen Lyn syncline using 77 bedding orientations indicates a best fit fold plunge of 14 , trending 245. Over 300 paleocurrent measurements were individually corrected for the plunge of the fold, and steeply dipping overturned bedding to yield the correct paleoflow direction.

Total Measurements $=319$

\section{UPPER SANDSTONE}

\section{Combined Flow Ripples}

\begin{tabular}{|c|c|c|c|}
\hline Bedding & $\underline{\text { Rake/Dir }}$ & $\frac{\text { Flow }}{\text { Direction }}$ & $\frac{\text { Corrected }}{\text { Trend }}$ \\
\hline \multirow[t]{2}{*}{$068,55 S$} & $64 \mathrm{E}$ & East & 1 \\
\hline & $45 \mathrm{E}$ & East & 340 \\
\hline \multirow[t]{2}{*}{$077,56 \mathrm{~S}$} & $78 \mathrm{E}$ & West & 335 \\
\hline & $82 \mathrm{E}$ & West & 330 \\
\hline $067,55 \mathrm{~S}$ & $32 \mathrm{E}$ & West & 10 \\
\hline \multirow[t]{8}{*}{$072,63 \mathrm{~S}$} & $10 W$ & West & 240 \\
\hline & $35 \mathrm{~W}$ & East & 85 \\
\hline & $10 \mathrm{E}$ & West & 219 \\
\hline & $15 \mathrm{E}$ & West & 214 \\
\hline & $10 \mathrm{E}$ & West & 219 \\
\hline & $10 \mathrm{E}$ & West & 219 \\
\hline & $14 \mathrm{E}$ & West & 216 \\
\hline & $18 \mathrm{E}$ & West & 211 \\
\hline \multirow[t]{8}{*}{$070,53 \mathrm{~S}$} & $14 \mathrm{E}$ & West & 207 \\
\hline & $19 \mathrm{E}$ & West & 202 \\
\hline & $20 \mathrm{E}$ & West & 200 \\
\hline & $20 \mathrm{E}$ & West & 200 \\
\hline & zero & West & 222 \\
\hline & $13 \mathrm{E}$ & West & 208 \\
\hline & $22 \mathrm{E}$ & West & 198 \\
\hline & $20 \mathrm{E}$ & West & 200 \\
\hline \multirow[t]{6}{*}{$070,59 \mathrm{~S}$} & zero & West & 227 \\
\hline & $13 \mathrm{E}$ & West & 214 \\
\hline & $10 \mathrm{E}$ & West & 217 \\
\hline & $6 \mathrm{E}$ & West & 221 \\
\hline & $18 \mathrm{E}$ & West & 207 \\
\hline & $14 \mathrm{E}$ & West & 212 \\
\hline \multirow[t]{3}{*}{$069,58 \mathrm{~S}$} & $29 \mathrm{E}$ & West & 195 \\
\hline & $10 \mathrm{E}$ & West & 213 \\
\hline & $20 \mathrm{E}$ & West & 204 \\
\hline
\end{tabular}




\section{Plant Stem Fragments}

Bedding Rake/Dir Corrected

\begin{tabular}{|c|c|c|}
\hline & & Trend \\
\hline $070,50 \mathrm{~S}$ & $55 \mathrm{E}$ & 168 \\
\hline \multirow[t]{12}{*}{$072,51 \mathrm{~S}$} & $67 \mathrm{E}$ & 155 \\
\hline & $67 \mathrm{E}$ & 155 \\
\hline & $76 \mathrm{E}$ & 146 \\
\hline & $73 \mathrm{E}$ & 149 \\
\hline & $64 \mathrm{E}$ & 159 \\
\hline & $64 \mathrm{E}$ & 159 \\
\hline & $60 \mathrm{E}$ & 162 \\
\hline & $70 \mathrm{E}$ & 152 \\
\hline & $90 \mathrm{E}$ & 312 \\
\hline & $65 \mathrm{E}$ & 157 \\
\hline & $70 \mathrm{E}$ & 152 \\
\hline & $30 \mathrm{E}$ & 192 \\
\hline \multirow[t]{8}{*}{$071,50 \mathrm{~S}$} & $25 \mathrm{E}$ & 198 \\
\hline & $24 \mathrm{E}$ & 198 \\
\hline & $05 \mathrm{E}$ & 217 \\
\hline & $25 \mathrm{E}$ & 198 \\
\hline & $20 \mathrm{E}$ & 202 \\
\hline & $45 \mathrm{E}$ & 177 \\
\hline & $35 \mathrm{E}$ & 187 \\
\hline & $60 \mathrm{~W}$ & 282 \\
\hline \multirow[t]{3}{*}{$072,51 \mathrm{~S}$} & $70 \mathrm{E}$ & 334 \\
\hline & $56 \mathrm{E}$ & 348 \\
\hline & $61 \mathrm{E}$ & 343 \\
\hline \multirow[t]{9}{*}{$065,50 \mathrm{~S}$} & $55 \mathrm{E}$ & 341 \\
\hline & $50 \mathrm{E}$ & 345 \\
\hline & $35 \mathrm{E}$ & 359 \\
\hline & $40 \mathrm{E}$ & 355 \\
\hline & $60 \mathrm{E}$ & 336 \\
\hline & $60 \mathrm{E}$ & 336 \\
\hline & $50 \mathrm{E}$ & 345 \\
\hline & $55 \mathrm{E}$ & 341 \\
\hline & $40 \mathrm{E}$ & 355 \\
\hline
\end{tabular}

\section{Current Lineations}

Bedding Rake/Dir Corrected

\begin{tabular}{|c|c|c|}
\multicolumn{2}{l}{} & \multicolumn{1}{c}{ Trend } \\
\hline $069,52 \mathrm{~S}$ & $87 \mathrm{~W}$ & 129 \\
\hline & $32 \mathrm{E}$ & 190 \\
\hline $064,54 \mathrm{~S}$ & $48 \mathrm{E}$ & 348 \\
\hline $068,55 \mathrm{~S}$ & $7 \mathrm{E}$ & 35 \\
\hline & $9 \mathrm{E}$ & 33 \\
\hline
\end{tabular}




\begin{tabular}{|c|c|c|}
\hline $062,56 \mathrm{~S}$ & $8 \mathrm{E}$ & 28 \\
\hline & $3 \mathrm{E}$ & 34 \\
\hline $066,58 \mathrm{~S}$ & $68 \mathrm{E}$ & 333 \\
\hline $065,50 \mathrm{~S}$ & $46 \mathrm{E}$ & 350 \\
\hline $065,55 \mathrm{~S}$ & $25 \mathrm{E}$ & 13 \\
\hline
\end{tabular}

Flute

Cast

Bedding Rake/Dir Flow Dir Corrected

Trend

\begin{tabular}{|l|c|c|c|}
\hline $065,50 \mathrm{~S}$ & $70 \mathrm{E}$ & West & 147 \\
\hline & $60 \mathrm{E}$ & West & 156 \\
\hline & $65 \mathrm{E}$ & West & 152 \\
\hline & $65 \mathrm{E}$ & West & 152 \\
\hline & $65 \mathrm{E}$ & West & 152 \\
\hline & $60 \mathrm{E}$ & West & 156 \\
\hline & $70 \mathrm{E}$ & West & 147 \\
\hline
\end{tabular}

Trough Cross-Beds

Bedding Rake/Dir Flow Dir Corrected

Trend

\begin{tabular}{|c|c|c|c|}
\hline $070,56 \mathrm{~S}$ & $28 \mathrm{E}$ & West & 194 \\
\hline & $25 \mathrm{E}$ & West & 199 \\
\hline & $40 \mathrm{E}$ & West & 183 \\
\hline & $30 \mathrm{E}$ & West & 192 \\
\hline & $48 \mathrm{E}$ & West & 176 \\
\hline & $50 \mathrm{E}$ & East & 354 \\
\hline & $25 \mathrm{E}$ & East & 19 \\
\hline & $50 \mathrm{E}$ & East & 354 \\
\hline & $40 \mathrm{E}$ & West & 183 \\
\hline $069,47 \mathrm{~S}$ & $35 \mathrm{E}$ & East & 4 \\
\hline & $25 \mathrm{E}$ & East & 14 \\
\hline & $20 \mathrm{E}$ & East & 19 \\
\hline & $20 \mathrm{E}$ & East & 19 \\
\hline & $70 \mathrm{E}$ & East & 330 \\
\hline & $30 \mathrm{E}$ & East & 9 \\
\hline & $40 \mathrm{E}$ & East & 358 \\
\hline & $35 \mathrm{E}$ & East & 4 \\
\hline & $13 \mathrm{E}$ & East & 24 \\
\hline & $70 \mathrm{E}$ & East & 330 \\
\hline $065,55 \mathrm{~S}$ & $32 \mathrm{E}$ & East & 101 \\
\hline & $19 \mathrm{~W}$ & East & 75 \\
\hline & $30 \mathrm{E}$ & East & 105 \\
\hline & $63 \mathrm{E}$ & East & 342 \\
\hline & $35 \mathrm{E}$ & East & 9 \\
\hline & $65 \mathrm{E}$ & East & 340 \\
\hline & $35 \mathrm{E}$ & East & 9 \\
\hline & & & \\
\hline
\end{tabular}




\section{LOWER SANDSTONE}

Flute Casts

Bedding Rake/Dir Flow Corrected Direction Trend

\begin{tabular}{|c|c|c|c|}
\hline $069,56 \mathrm{~S}$ & $40 \mathrm{~W}$ & West & 264 \\
\hline \multirow[t]{9}{*}{$070,56 \mathrm{~S}$} & $10 \mathrm{~W}$ & West & 236 \\
\hline & $30 \mathrm{~W}$ & West & 254 \\
\hline & $35 \mathrm{~W}$ & West & 260 \\
\hline & $25 \mathrm{~W}$ & West & 248 \\
\hline & $45 \mathrm{~W}$ & West & 268 \\
\hline & $20 \mathrm{~W}$ & West & 243 \\
\hline & $30 \mathrm{~W}$ & West & 252 \\
\hline & $35 \mathrm{~W}$ & West & 257 \\
\hline & $37 \mathrm{~W}$ & West & 259 \\
\hline \multirow[t]{2}{*}{$071,53 \mathrm{~S}$} & $15 \mathrm{~W}$ & West & 238 \\
\hline & $20 \mathrm{~W}$ & West & 245 \\
\hline \multirow[t]{3}{*}{$068,58 \mathrm{~S}$} & $24 \mathrm{~W}$ & West & 246 \\
\hline & $05 \mathrm{~W}$ & West & 226 \\
\hline & $27 \mathrm{~W}$ & West & 249 \\
\hline \multirow[t]{6}{*}{$057,60 \mathrm{~S}$} & $30 \mathrm{~W}$ & West & 245 \\
\hline & $34 \mathrm{~W}$ & West & 248 \\
\hline & $44 \mathrm{~W}$ & West & 258 \\
\hline & zero & West & 214 \\
\hline & $29 \mathrm{~W}$ & West & 243 \\
\hline & $25 \mathrm{~W}$ & West & 239 \\
\hline \multirow[t]{5}{*}{$067,55 \mathrm{~S}$} & $27 \mathrm{~W}$ & West & 247 \\
\hline & $24 \mathrm{~W}$ & West & 245 \\
\hline & $25 \mathrm{~W}$ & West & 246 \\
\hline & $27 \mathrm{~W}$ & West & 247 \\
\hline & $36 \mathrm{~W}$ & West & 257 \\
\hline \multirow[t]{4}{*}{$068,52 \mathrm{~S}$} & $34 \mathrm{~W}$ & West & 254 \\
\hline & $34 \mathrm{~W}$ & West & 254 \\
\hline & $37 \mathrm{~W}$ & West & 258 \\
\hline & $32 \mathrm{~W}$ & West & 251 \\
\hline \multirow[t]{2}{*}{$065,58 \mathrm{~S}$} & $25 \mathrm{~W}$ & West & 244 \\
\hline & $29 \mathrm{~W}$ & West & 248 \\
\hline \multirow[t]{3}{*}{$060,55 \mathrm{~S}$} & $35 \mathrm{~W}$ & West & 249 \\
\hline & $38 \mathrm{~W}$ & West & 252 \\
\hline & $40 \mathrm{~W}$ & West & 254 \\
\hline \multirow[t]{2}{*}{$076,55 \mathrm{~S}$} & $27 \mathrm{~W}$ & West & 255 \\
\hline & $22 \mathrm{~W}$ & West & 250 \\
\hline $074,56 \mathrm{~S}$ & $67 \mathrm{E}$ & West & 164 \\
\hline \multirow[t]{4}{*}{$052,59 \mathrm{~S}$} & $25 \mathrm{~W}$ & East & 55 \\
\hline & $30 \mathrm{~W}$ & East & 58 \\
\hline & $30 \mathrm{~W}$ & East & 58 \\
\hline & $15 \mathrm{~W}$ & East & 46 \\
\hline
\end{tabular}




\section{Groove Casts}

Bedding Rake/Dir Corrected

\begin{tabular}{|c|c|c|}
\hline & & end \\
\hline $072,54 \mathrm{~S}$ & $35 \mathrm{~W}$ & 260 \\
\hline & $37 \mathrm{~W}$ & 262 \\
\hline $079,58 \mathrm{~S}$ & $74 \mathrm{~W}$ & 302 \\
\hline $078,57 \mathrm{~S}$ & $\overline{72 \mathrm{~W}}$ & 301 \\
\hline $072,58 \mathrm{~S}$ & $71 \mathrm{~W}$ & 300 \\
\hline & $25 \mathrm{~W}$ & 252 \\
\hline & $06 \mathrm{~W}$ & 54 \\
\hline & $28 \mathrm{~W}$ & 254 \\
\hline & $20 \mathrm{~W}$ & 248 \\
\hline & $25 \mathrm{~W}$ & 252 \\
\hline & $28 \mathrm{~W}$ & 254 \\
\hline & $60 \mathrm{~W}$ & 288 \\
\hline & $30 \mathrm{~W}$ & 258 \\
\hline & $25 \mathrm{~W}$ & 252 \\
\hline & $13 \mathrm{~W}$ & 238 \\
\hline $067,55 \mathrm{~S}$ & $35 \mathrm{~W}$ & 255 \\
\hline & $28 \mathrm{~W}$ & 249 \\
\hline $068,52 \mathrm{~S}$ & $21 \mathrm{~W}$ & 242 \\
\hline & $35 \mathrm{~W}$ & 256 \\
\hline & $40 \mathrm{~W}$ & 261 \\
\hline & $18 \mathrm{~W}$ & 238 \\
\hline $060,55 \mathrm{~S}$ & $25 \mathrm{~W}$ & 239 \\
\hline & $15 \mathrm{~W}$ & 227 \\
\hline & $37 \mathrm{~W}$ & 252 \\
\hline & $27 \mathrm{~W}$ & 241 \\
\hline & $27 \mathrm{~W}$ & 241 \\
\hline & $27 \mathrm{~W}$ & 241 \\
\hline $069,57 \mathrm{~S}$ & $35 \mathrm{~W}$ & 258 \\
\hline & $37 \mathrm{~W}$ & 260 \\
\hline & $40 \mathrm{~W}$ & 263 \\
\hline & $37 \mathrm{~W}$ & 260 \\
\hline & $30 \mathrm{~W}$ & 253 \\
\hline $071,53 \mathrm{~S}$ & $30 \mathrm{~W}$ & 254 \\
\hline & $24 \mathrm{~W}$ & 247 \\
\hline & $25 \mathrm{~W}$ & 248 \\
\hline & $35 \mathrm{~W}$ & 258 \\
\hline $068,58 \mathrm{~S}$ & $25 \mathrm{~W}$ & 249 \\
\hline $057,60 \mathrm{~S}$ & $27 \mathrm{~W}$ & 243 \\
\hline & $30 \mathrm{~W}$ & 245 \\
\hline & $35 \mathrm{~W}$ & 250 \\
\hline & $35 \mathrm{~W}$ & 250 \\
\hline & $25 \mathrm{~W}$ & 239 \\
\hline & $40 \mathrm{~W}$ & 255 \\
\hline $067,55 \mathrm{~S}$ & $20 \mathrm{~W}$ & 240 \\
\hline
\end{tabular}




\begin{tabular}{|l|c|c|}
\hline $074,56 \mathrm{~S}$ & $62 \mathrm{E}$ & 344 \\
\hline & $55 \mathrm{E}$ & 352 \\
\hline $052,59 \mathrm{~S}$ & $25 \mathrm{~W}$ & 236 \\
\hline & $27 \mathrm{~W}$ & 237 \\
\hline & $16 \mathrm{~W}$ & 227 \\
\hline & $25 \mathrm{~W}$ & 235 \\
\hline & $22 \mathrm{~W}$ & 232 \\
\hline & $22 \mathrm{~W}$ & 232 \\
\hline & $25 \mathrm{~W}$ & 235 \\
\hline & $08 \mathrm{~W}$ & 217 \\
\hline $079,60 \mathrm{~S}$ & zero & 233 \\
\hline & zero & 233 \\
\hline & zero & 233 \\
\hline & zero & 233 \\
\hline $079,52 \mathrm{~S}$ & $47 \mathrm{~W}$ & 279 \\
\hline & $57 \mathrm{~W}$ & 289 \\
\hline
\end{tabular}

\section{Current Lineations}

Bedding Rake/Dir Corrected

Trend

\begin{tabular}{|c|c|c|}
\hline \multirow[t]{7}{*}{$072,58 \mathrm{~S}$} & $67 \mathrm{~W}$ & 290 \\
\hline & $64 \mathrm{~W}$ & 293 \\
\hline & $27 \mathrm{~W}$ & 253 \\
\hline & $85 \mathrm{~W}$ & 313 \\
\hline & $18 \mathrm{~W}$ & 243 \\
\hline & $35 \mathrm{~W}$ & 262 \\
\hline & $17 \mathrm{~W}$ & 242 \\
\hline \multirow{2}{*}{$072,54 \mathrm{~S}$} & $30 \mathrm{~W}$ & 255 \\
\hline & $25 \mathrm{~W}$ & 252 \\
\hline $069,53 \mathrm{~S}$ & $30 \mathrm{~W}$ & 250 \\
\hline $069,57 \mathrm{~S}$ & $25 \mathrm{~W}$ & 251 \\
\hline \multirow[t]{2}{*}{$073,56 \mathrm{~S}$} & $35 \mathrm{~W}$ & 262 \\
\hline & $30 \mathrm{~W}$ & 258 \\
\hline \multirow[t]{3}{*}{$057,60 \mathrm{~S}$} & $44 \mathrm{~W}$ & 260 \\
\hline & $36 \mathrm{~W}$ & 251 \\
\hline & $40 \mathrm{~W}$ & 255 \\
\hline \multirow[t]{2}{*}{$065,58 \mathrm{~S}$} & $37 \mathrm{~W}$ & 258 \\
\hline & $38 \mathrm{~W}$ & 260 \\
\hline \multirow[t]{2}{*}{$069,55 \mathrm{~S}$} & $20 \mathrm{~W}$ & 241 \\
\hline & $27 \mathrm{~W}$ & 248 \\
\hline \multirow[t]{2}{*}{$068,50 \mathrm{~S}$} & $24 \mathrm{~W}$ & 243 \\
\hline & $34 \mathrm{~W}$ & 252 \\
\hline $071,54 \mathrm{~S}$ & $32 \mathrm{~W}$ & 256 \\
\hline $065,56 \mathrm{~S}$ & $18 \mathrm{~W}$ & 236 \\
\hline $073,63 \mathrm{~S}$ & $55 \mathrm{E}$ & 285 \\
\hline $082,55 \mathrm{~S}$ & $25 \mathrm{~W}$ & 259 \\
\hline $062,62 \mathrm{~S}$ & $42 \mathrm{~W}$ & 263 \\
\hline
\end{tabular}


Trough Cross-Beds

Bedding Rake/Dir Flow Corrected

Direction Trends

\begin{tabular}{|c|c|c|c|}
\hline \multirow[t]{11}{*}{$079,58 \mathrm{~S}$} & $72 \mathrm{E}$ & East & 342 \\
\hline & $76 \mathrm{E}$ & East & 338 \\
\hline & $07 \mathrm{~W}$ & West & 249 \\
\hline & $07 \mathrm{~W}$ & West & 249 \\
\hline & $06 \mathrm{~W}$ & West & 249 \\
\hline & $66 \mathrm{~W}$ & West & 301 \\
\hline & $74 \mathrm{~W}$ & West & 310 \\
\hline & $73 \mathrm{~W}$ & West & 308 \\
\hline & $21 \mathrm{E}$ & East & 32 \\
\hline & $60 \mathrm{~W}$ & West & 294 \\
\hline & $70 \mathrm{~W}$ & West & 303 \\
\hline \multirow{8}{*}{$068,58 \mathrm{~S}$} & $89 \mathrm{E}$ & West & 138 \\
\hline & $44 \mathrm{~W}$ & East & 90 \\
\hline & $87 \mathrm{~W}$ & East & 133 \\
\hline & $16 \mathrm{~W}$ & East & 63 \\
\hline & $46 \mathrm{~W}$ & East & 9 \\
\hline & $46 \mathrm{~W}$ & East & 92 \\
\hline & $86 \mathrm{E}$ & West & 140 \\
\hline & $07 \mathrm{~W}$ & West & 233 \\
\hline $070,55 \mathrm{~S}$ & $52 \mathrm{~W}$ & West & 276 \\
\hline \multirow{5}{*}{$069,55 \mathrm{~S}$} & $35 \mathrm{~W}$ & West & 257 \\
\hline & $44 \mathrm{~W}$ & East & 86 \\
\hline & $25 \mathrm{~W}$ & West & 247 \\
\hline & $18 \mathrm{~W}$ & East & 61 \\
\hline & $55 \mathrm{~W}$ & East & 96 \\
\hline \multirow[t]{6}{*}{$068,50 \mathrm{~S}$} & $41 \mathrm{~W}$ & East & 80 \\
\hline & $44 \mathrm{~W}$ & East & 83 \\
\hline & $52 \mathrm{~W}$ & East & 90 \\
\hline & $43 \mathrm{~W}$ & East & 81 \\
\hline & $57 \mathrm{~W}$ & East & 96 \\
\hline & $40 \mathrm{~W}$ & West & 256 \\
\hline \multirow[t]{5}{*}{$071,54 \mathrm{~S}$} & $62 \mathrm{~W}$ & East & 116 \\
\hline & $66 \mathrm{~W}$ & East & 121 \\
\hline & $46 \mathrm{~W}$ & East & 111 \\
\hline & $36 \mathrm{~W}$ & East & 101 \\
\hline & $32 \mathrm{~W}$ & East & 99 \\
\hline \multirow[t]{5}{*}{$066,52 \mathrm{~S}$} & $03 \mathrm{~W}$ & West & 220 \\
\hline & $54 \mathrm{~W}$ & East & 93 \\
\hline & $50 \mathrm{~W}$ & West & 269 \\
\hline & $63 \mathrm{~W}$ & East & 103 \\
\hline & $18 \mathrm{~W}$ & West & 236 \\
\hline \multirow[t]{5}{*}{$073,63 \mathrm{~S}$} & $65 \mathrm{E}$ & West & 145 \\
\hline & $72 \mathrm{E}$ & East & 340 \\
\hline & $75 \mathrm{E}$ & East & 337 \\
\hline & $45 \mathrm{E}$ & East & 8 \\
\hline & $55 \mathrm{E}$ & West & 177 \\
\hline
\end{tabular}




\begin{tabular}{|c|c|c|c|}
\hline & $60 \mathrm{E}$ & West & 152 \\
\hline & $40 \mathrm{E}$ & East & 10 \\
\hline & $57 \mathrm{E}$ & West & 174 \\
\hline & $49 \mathrm{E}$ & East & 2 \\
\hline & $38 \mathrm{E}$ & West & 192 \\
\hline $061,60 \mathrm{~S}$ & $20 \mathrm{~W}$ & West & 237 \\
\hline & $10 \mathrm{~W}$ & West & 228 \\
\hline & $8 \mathrm{~W}$ & West & 225 \\
\hline & $10 \mathrm{E}$ & West & 206 \\
\hline & $6 \mathrm{E}$ & West & 210 \\
\hline $079,52 \mathrm{~S}$ & $50 \mathrm{~W}$ & West & 289 \\
\hline & $62 \mathrm{~W}$ & West & 300 \\
\hline & $60 \mathrm{~W}$ & West & 298 \\
\hline & $55 \mathrm{~W}$ & West & 294 \\
\hline & $55 \mathrm{~W}$ & West & 294 \\
\hline & $64 \mathrm{~W}$ & West & 304 \\
\hline & $42 \mathrm{~W}$ & West & 271 \\
\hline & $34 \mathrm{~W}$ & West & 263 \\
\hline & $63 \mathrm{~W}$ & West & 302 \\
\hline & $67 \mathrm{~W}$ & West & 306 \\
\hline
\end{tabular}

Combined Flow Ripples

Bedding Rake/Dir Flow Corrected

Direction Trends

\begin{tabular}{|c|c|c|c|}
\hline $061,56 \mathrm{~S}$ & $49 \mathrm{~W}$ & East & 86 \\
\hline & $60 \mathrm{~W}$ & East & 98 \\
\hline $068,58 \mathrm{~S}$ & $37 \mathrm{~W}$ & East & 82 \\
\hline & $23 \mathrm{~W}$ & East & 66 \\
\hline & $52 \mathrm{~W}$ & East & 97 \\
\hline $069,56 \mathrm{~S}$ & $52 \mathrm{~W}$ & East & 97 \\
\hline & $42 \mathrm{~W}$ & East & 87 \\
\hline & $39 \mathrm{~W}$ & East & 84 \\
\hline & $35 \mathrm{~W}$ & East & 79 \\
\hline & $38 \mathrm{~W}$ & East & 83 \\
\hline & $33 \mathrm{~W}$ & East & 77 \\
\hline $070,55 \mathrm{~S}$ & $23 \mathrm{~W}$ & West & 247 \\
\hline & $25 \mathrm{~W}$ & West & 249 \\
\hline $069,55 \mathrm{~S}$ & $61 \mathrm{~W}$ & East & 105 \\
\hline & $26 \mathrm{~W}$ & East & 69 \\
\hline & $35 \mathrm{~W}$ & East & 78 \\
\hline & $44 \mathrm{~W}$ & East & 87 \\
\hline & $67 \mathrm{~W}$ & East & 111 \\
\hline
\end{tabular}

